Santina Raffaella Lucente

\begin{abstract}
A Desigualdade na Europa: sua definição, importância e origem analisada através do papel do Estado e da mundialização do capital
\end{abstract}

Dissertação de Mestrado

Dissertação apresentada como requisito parcial para obtenção do título de Mestre pelo Programa de Pósgraduação em Relações Internacionais do Instituto de Relações Internacionais da PUC-Rio.

Orientador: Prof. Luís Manuel Fernandes Co-orientadora: Profa. Ana Elisa Saggioro Garcia Muller

Rio de Janeiro

Setembro de 2014 


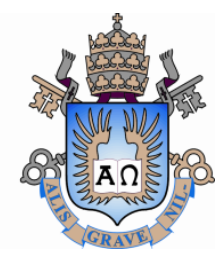

Santina Raffaella Lucente

\section{A Desigualdade na Europa: sua definição, importância e origem analisada através do papel do Estado e da mundialização do capital}

Dissertação apresentada como requisito parcial para obtenção do título de Mestre pelo Programa de Pós-graduação em Relações Internacionais do Instituto de Relações Internacionais da PUC-Rio. Aprovada pela Comissão Examinadora abaixo assinada.

Prof. Luís Manuel Fernandes

Orientador

Instituto de Relações Internacionais - PUC-Rio

Profa. Ana Elisa Saggioro Garcia Muller

Co-orientadora

Universidade Federal Rural do Rio de Janeiro - UFRRJ

Prof. Ernani Teixeira Torres Filho

Universidade Federal do Rio de Janeiro - UFRJ

Profa. Mônica Herz

Vice-Decana de Pós-Graduação

do Centro de Ciências Sociais - PUC-Rio

Rio de Janeiro, 29 de Setembro de 2014 
Todos os direitos reservados. É proibida a reprodução total ou parcial do trabalho sem a autorização da universidade, da autora e do orientador.

\section{Santina Raffaella Lucente}

Graduou-se em Economia da Cooperação Internacional e do Desenvolvimento (com habilitação em Relações Internacionais) na Faculdade de Economia da Università degli Studi di Roma "La Sapienza" em 2009 (diploma revalidado no Brasil pelo Ministério da Educação em "Relações Internacionais" pela Universidade Federal Fluminense - UFF - em 2011). Pós-graduou-se em Relações Internacionais Contemporâneas pela Pontifícia Universidade Católica do Rio de Janeiro - PUC-Rio. Trabalha como assistente de pesquisa pela FGV-CPDOC desde 2014.

Ficha Catalográfica

\section{Lucente, Santina Raffaella}

A desigualdade na Europa: sua definição, importância e origem analisada através do papel do Estado e da mundialização do capital / Santina Raffaella Lucente ; orientador: Luís Manoel Fernandes. - 2014. 106 f. : il. (color.) ; $30 \mathrm{~cm}$

$$
\text { Dissertação }
$$$$
\text { (mestrado)-Pontifícia }
$$

Universidade Católica do Rio de Janeiro, Instituto de Relações Internacionais, 2014.

Inclui bibliografia

1. Relações internacionais - Teses. 2. Desigualdade. 3. Polarização. 4. Europa. 5. Economia capitalista mundial. 6. Desenvolvimento desigual. 7. Distribuição de renda. 8. Estado e mercado. I. Fernandes, Luís Manoel. II. Pontifícia Universidade Católica do Rio de Janeiro. Instituto de Relações Internacionais. III. Título. 


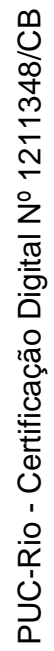

À minha família 


\section{Agradecimentos}

O ano de 2014 é particularmente significativo para minha carreira acadêmica pois passaram-se exatamente dez anos desde minha entrada na academia. Foi uma década muito mais profícua do que eu imaginava no dia em que ingressei no departamento de Economia da "Università degli Studi di Roma, La Sapienza". Desde então, desenvolvi um interesse sincero pelas questões que envolvem o fenômeno da desigualdade no mundo. $\mathrm{O}$ interesse foi alimentado graças a uma troca inexaurível de ideias, materiais e experiências únicas com os meus colegas do curso de Economia da Cooperação Internacional e do Desenvolvimento que se tornaram amigos inseparáveis e peças importantíssimas na minha coleção de vitórias. À parte o entusiasmo louvável, o que forneceu as bases mais sólidas sobre as quais minha pesquisa começou a ser construída, foi um entendimento mais profundo sobre as relações materiais que a história presenciou e que explicam todos os fenômenos pelos quais já vinha me interessando anteriormente. O Prof. Gianfranco Pala, me endereçou para esse tipo de estudo e devo a ele a paixão que, dez anos mais tarde, orienta minha vida acadêmica em uma ontologia que sempre precisa de novos diálogos.

Com a vinda ao Brasil, a pós-graduação em Relações Internacionais ajudou-me a colocar a pesquisa em novos trilhos e fui incentivada pelo Prof. Arthur Bernardes a entrar no programa de mestrado. Agradeço ele pelas longas conversas que me ajudaram a abrir um novo e produtivo capítulo da minha vida. Foi durante o curso, também, que conheci meu amigo Rodrigo, hoje grande inspiração tanto para a minha vida profissional quanto para meu crescimento como ser humano.

O Mestrado em RI não foi somente um marco importante em minha vida acadêmica, mas representou para mim um novo mundo e campo de ação constituído por novas regras e relações. O programa permitiu-me aprender novas maneiras de pensar e alguns professores contribuíram de forma substancial à minha formação. Entre eles, o Prof. Gomez, incansável interlocutor, o Prof. Luís Fernandes e a Prof. Ana Garcia, que aceitaram me orientar nesse trabalho e 
contribuíram de forma indispensável, o Prof. Ernani Torres, do programa PEPI da UFRJ, cuja matéria cursada em 2013 conferiu o "toque" mais econômico que eu queria dar ao meu trabalho, e os Prof. Miguel Borba de Sá e Prof. Antônio Sucupira, com os quais fiz minhas primeiras e determinantes experiências na docência.

Durante estes dois anos do mestrado, conheci ótimos colegas que também se tornaram companheiros de quotidiano. Com eles cresci tanto nos momentos ruins marcados por derrotas quanto nos momentos de vitórias e conquistas. Por causa da peculiaridade do programa e da dedicação requerida, tornamo-nos uma grande família, exemplo de solidariedade e de ajuda fraternal. Preciso agradecê-los muito, pois tenho certeza que, sem seu apoio, não teria redigido este trabalho e jamais poderia comemorar essa nova etapa.

Filipe, meu companheiro de vida, nunca cansou durante estes anos de me incentivar, de acreditar em mim. Às vezes elogiou meu trabalho, outras vezes, com críticas veementes e duras, ajudou-me a melhorar e a crescer mais um pouco. Foi a pessoa que me ensinou a exigir sempre mais de mim mesma.

Por fim, o agradecimento mais importante vai à minha família. Meu pai, incansável otimista, melhor pai do mundo. O orgulho que ele sente de mim se multiplica no que eu sinto por ele. Tudo que ele me proporcionou e o apoio constante e incondicional que me deu não tem como medir. Minha irmã sempre foi minha outra metade e minha âncora nos momentos difíceis. Com ela, um olhar ou um abraço foram sempre mais importantes que mil palavras e sua força virava minha força. Minha mãe, pesquisadora da vida e curiosa dos objetos de todos meus trabalhos, me disse um dia "nunca pare de estudar". Fiz dessas palavras meu norte e, desde 2004, nunca parei de acreditar que, com um estudo mais profundo desses fenômenos, podemos nos tornar pessoas mais iluminadas, capazes de pensar o mundo de forma mais atenta, respeitosa e eficaz. 


\section{Resumo}

Lucente, Santina Raffaella; Fernandes, Luís Manoel. A desigualdade na Europa: sua definição, importância e origem analisada através do papel do Estado e da mundialização do capital. Rio de Janeiro, 2014. 106 p. Dissertação de Mestrado - Instituto de Relações Internacionais, Pontifícia Universidade Católica do Rio de Janeiro.

A desigualdade, em suas diversas manifestações, está no centro do debate da economia política há algumas décadas. Dentre dos principais fatores que influenciam as vertentes interessadas nesse debate, há as orientações políticas e a visão de como o Estado se relaciona com o mercado e com a sociedade. $\mathrm{Na}$ Europa, em contraste com a ideia segundo a qual os Estados mais "desenvolvidos" deveriam ter condições de vida melhores, observou-se, nos últimos cinquenta anos, uma queda (média) dos índices de bem estar socioeconômicos. Isto, embora esteja de acordo com a maioria dos estudos desenvolvidos, não é um ponto de partida suficiente para uma análise mais aprofundada sobre a realidade dos países europeus nos dias de hoje. Ao se pesquisar os indicadores de desigualdade dos países dessa área, percebeu-se uma tendência às mudanças de caráter regional que levariam a algumas hipóteses de que determinados países, com economia e história parecida, teriam seguido o mesmo caminho de aumento/diminuição do nível de desigualdade. O que foi apontado, apesar de já ser muito interessante, foi tomando uma forma ainda mais relevante quando se viu que os agrupamentos por regiões respeitavam, também, essas tendências sob uma chave de leitura de concentração de renda e de estrutura e mobilidade social. Se o índice de Gini (principal índice utilizado para a definição do nível de desigualdade) já pode ser visto como um fator relevante para se estudar a evolução socioeconômica desses países, resulta ainda mais profícuo associar a esse estudo uma análise sobre a polarização das rendas para se ter uma maior clareza sobre o que aconteceu de fato, e de forma mais dinâmica, nos diversos países ao longo do período considerado. As tendências encontradas com esta última análise não só revelam fatores muito peculiares em relação às diversas políticas adotadas pelos respectivos Estados, quanto constituem uma sequência de todos os momentos em que houve mudanças tanto no mercado internacional quanto no interno (como sua consequência). 
Com o objetivo de entender que tipo de mudanças se manifestaram nos países da região europeia, quais foram as mais significativas e como podem ser explicadas de forma inicial para futuros estudos, essa pesquisa procura se colocar como uma análise multidimensional sobre os fenômenos mais abrangentes que o mercado e o Capital internacional geraram nas dimensões estatais. Seguindo uma vertente crítica que ponha essas problemáticas em um plano aberto de análises dinâmicas, contínuas e sem um ponto final às múltiplas respostas a serem encontradas, uma indagação na chave do materialismo histórico marxiano e marxista constituirá a metodologia, as fontes e as escolhas analíticas que serão utilizadas.

\section{Palavras-chave}

Desigualdade; Polarização; Europa; economia capitalista mundial; desenvolvimento desigual; distribuição de renda; estado e mercado. 


\section{Abstract}

Lucente, Santina Raffaella; Fernandes, Luís Manoel (Advisor). Inequality in Europe: its definition, relevance, and origin analyzed through the role of the State and the capital worldwide expansion.. Rio de Janeiro, 2014. 106 p. MSc. Dissertation - Instituto de Relações Internacionais, Pontifícia Universidade Católica do Rio de Janeiro.

Inequality, in its different forms, was putted in the middle of the political economy debate for decades. One of the main factors that influenced both sides involved in this debate, besides political orientations, stands the view of how the State interacts with the market e with the society. In Europe, on the opposite side of thinking about the more developed is a State the more its society is living in better conditions, in the last fifty years a decrease of all the socioeconomic indices was observed. That, although it is a very significant point in common among all the academic works, it is not satisfying for a deeper analysis on the nowadays European countries reality. Searching for the area's countries inequality factors, a tendency to change was observed regionally. That could suggests a common path for the countries of the same area, that has had leaded to same inequality indices. What was pointed out, although is yet a very prominent subject to be studied, it was just the beginning of a more relevant observation when common points suggesting closer clustering of income concentration and social mobility structure was found out. If Gini Index (the main index used to measure inequality) could be seen yet as a relevant factor to study socioeconomic evolution of those countries, it is even more profitable to link an analysis leaded by income polarization indices to this research, in order to see clearer what happened to the European countries, socially and economically speaking, during the chosen period. Founded trends thanks to this kind of analysis not just show us some peculiarities about the diverse politics used by different States, but also sets a time-laps of every single event in which, both on the international and national market, significant changes has happened as its consequence. With the goal of catching these king of changes of the European area, which ones were more relevant and how they can be explained for future understandings, this dissertation try to work as a multidimensional analysis about wider phenomena caused by international market and capital on the national plane. Following a critical theory that puts all that issues on a wider plane of investigation, a Marxian 
historical materialism analysis leads the main methodology of the research, as well as the analytical choices and sources to be used.

\section{Keywords}

Inequality; Polarization, Europe; world capitalist economy; unequal development; income distribution; state and market. 


\section{Sumário}

$\begin{array}{ll}\text { 1. Introdução } & 16\end{array}$

$\begin{array}{ll}\text { 2. Metodologia } & 20\end{array}$

3. O papel do Estado e do Mercado 30

4. A desigualdade intra-países e as tendências regionais 41

4.1 A desigualdade e a distribuição de renda 41

4.2 Conceito de polarização e transformação estrutural 47

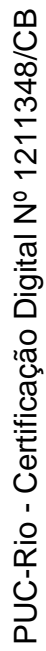

5. As Macro-Regiões 51

5.1 Europa Central 54

5.2 Europa do Leste $\quad 55$

5.3 Europa do Norte 58

5.4 Europa do Sul $\quad 59$

$\begin{array}{ll}5.5 \text { Um olhar sobre os EUA } & 60\end{array}$

6. Alguns países e seus históricos 62

6.1 França, Alemanha 62

6.2 Grã Bretanha, Irlanda $\quad 70$

6.3 Romênia, Bulgária $\quad 77$

6.4 Itália, Grécia $\quad 87$

7. Conclusões 95

8. Apêndice 98

9. Referências Bibliográficas 100 


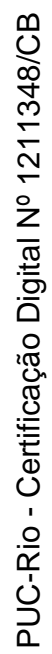




\section{Lista de Gráficos}

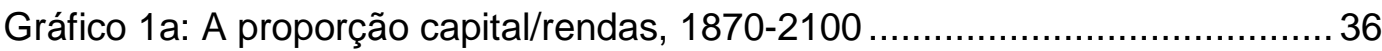

Gráfico 1b: Capital na França, 1700-2010 .................................................... 38

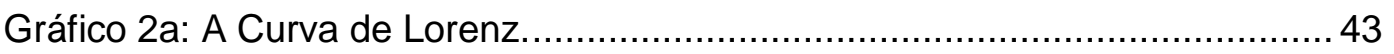

Gráfico 2b: Parcelas de rendas nas 4 fatias acumuladas de $25 \%$

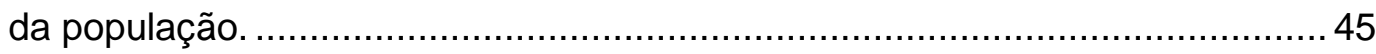

Gráfico 3: Concentração das rendas de uma população com

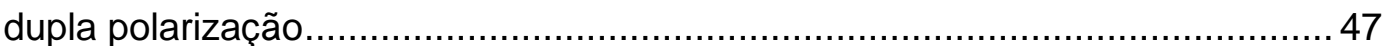

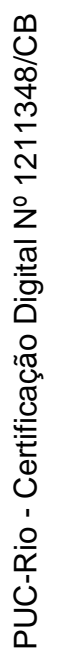

Gráfico 4: Índice de Gini pré e pós transição do regime

econômico nos países ex-soviéticos ......................................................... 55

Gráfico 5: Concentração de renda do decil mais rico da

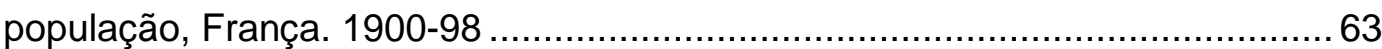

Gráfico 6: Distribuição relativa de rendas na França,

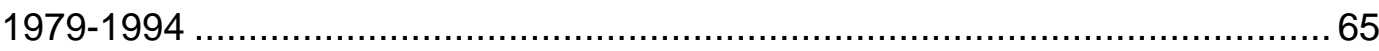

Gráfico 7: Índice de Polarização Social (DER 1) da

Alemanha por quinquênios. 1970-2005

67

Gráfico 8a: Distribuição de renda por decis na Grã Bretanha.

$1979-2004$ 72

Gráfico 8b: Distribuição de renda por decis nos Estados Unidos.

$1979-2004$ 72

Gráfico 9: Evolução de Gini na Bulgária. 1980-2010 83

Gráfico 10: Índices de polarização relativa na Itália, 1989-2006 88 
Gráfico 11: Distribuição relativa das rendas na Itália, 1986-2000. 89

Gráfico 12: Salários proporcionais ao PIB na Grécia. 1970-2011 92

Gráfico 13: Curva de Polarização Absoluta na Grécia, 2010 93

Gráfico 14: Taxa de risco à pobreza da Grécia. 2008-2012 94

\section{Lista de Tabelas}

Tabela 1: Desigualdade das rendas totais (trabalho e capital) no tempo e no espaço.

Tabela 2: Evolução quinquenal de Gini da Europa por regiões.

$1970-2005$ 52

Tabela 3: O impacto da redistribuição na bi-polarização de rendas 78

Tabela 4a: Estrutura da arrecadação de impostos por tipo e

por base do imposto na Bulgária. 2000-2010. (\% do PIB) 85

Tabela 4b: Desigualdade e polarização da parte da

população trabalhadora. (Gini, centis $80 / 20$, centis $90 / 10$ ) .85

Tabela 5: Rendas disponíveis por núcleo familiar na Itália, 1989-2006. 88 
Ao júri o julgamento.

O júri, no nosso caso, são os leitores.

Haverá quem, apavorado pelas suspeitas levantadas, não levará em conta as respostas pacientemente, objetivamente recolhidas pelo juiz, e haverá quem, impressionado pela coincidência das respostas, porá de lado qualquer suspeita; outro, mais prudente, pensará que as conclusões trazidas por essas respostas se deverão aceitar ou ponderar ou recusar segundo os casos e segundo os usos prefixados.

C. Gini, 1922 


\section{1. Introdução}

O aumento da desigualdade é um dos maiores problemas econômicos e sociais da nossa época, cujos efeitos são diversos. Sobre o mercado do trabalho, alimenta o círculo vicioso entre empregos de qualificação baixa, salários baixos e aumento da pobreza. Tem efeitos intergeracionais, pois cria uma sociedade onde os espaços de mobilidade social são cada vez mais reduzidos. Tem efeitos sociais visíveis no crescimento da pobreza, com os diversos problemas relacionados aos processos de marginalização e desintegração social. Tem efeitos sobre as políticas redistributivas, com a dificuldade crescente dos sistemas de welfare de compensação através das ferramentas disponíveis, e as medidas drasticamente reduzidas pela austeridade, a deterioração das disparidades e os problemas sociais. Tem, por fim, importantes efeitos sobre a política per si, pois reflete a concentração crescente de poder e riqueza em uma elite cada vez mais separada do resto da sociedade, alimentando dinâmicas (dos presidencialismos aos populismos) que podem representar uma ameaça à democracia. Mais difícil que avaliar os efeitos nefastos da desigualdade, é entender quais são suas causas e o que pode ser feito para amenizar esses diagnósticos.

Quando pensamos na concentração de renda e na desigualdade, na verdade não estamos apresentando meros dados estatísticos. A motivação de uma constatação desse tipo se baseia mais na pergunta “o que isso implica?", e a resposta, conforme se vê na maioria dos produções acadêmicas das RI e das Ciências Políticas, está na oportunidade de reflexão sobre como interceder naquela realidade. Nesse caso, no da desigualdade dos países europeus, lugar circunscrito que já presenciou inúmeras manobras sócio-político-econômico-fiscais, podemos dizer que, embora tenha havido tendências dependendo da época histórica, nunca sobressaiu com unanimidade uma solução.

Podemos, outrossim, dizer que não existe lugar no mundo onde já teve um tipo de consenso que não encontrasse um mínimo de resistência. De toda forma, a Europa 
apresenta elementos interessantíssimos nos últimos 100 anos, sobretudo por ter sido cenário vivo de guerras e reconstruções, por ter uma posição estratégica que nas diversas épocas apresentou vantagens diversas e por ser o único exemplo do mundo onde, por vários motivos, houve a realização de um agrupamento amplo entre países com interesses díspares e que já combateram entre si. Parece que essas peculiaridades seriam suficientes para se estudar essa área, quando aparece um outro aspecto que é ainda mais saliente para o estudo a ser executado: a Europa é o berço de nascença de bancos, dinheiro, acumulação, crédito, industrialização; em um conceito único, do moderno capitalismo.

Com essas condições, a área contou com uma acumulação muito elevada dependendo do contexto histórico, embora tenha protagonizado recessões, stagflações e, mais em geral, crises que alteraram sazonalmente a concentração de renda, seja por políticas aplicadas internamente, seja, em outros momentos, por motivos "sistêmicos".

Em seu último trabalho, Piketty (2013) coloca no centro dos mecanismos que alimentaram as desigualdades a evolução da relação capital total/renda. O valor do estoque de todas as riquezas privadas - imobiliárias e financeiras - em relação ao produto nacional seguiu uma curva em "U" na maioria dos países, passando de valores superiores a 6 no início do século passado, para valores perto de 3 no segundo pós-guerra, subindo de novo para 4 em 2000 e, novamente, para quase 6 em $2013^{1}$.

Nos últimos quarenta anos, o rendimento das riquezas superou o ritmo de crescimento da renda, resultando em fatias cada vez maiores de rendas industriais, de imóveis e financeiras. Esta é hoje, segundo Piketty, "a contradição crucial do capitalismo"2.

Na pesquisa serão abordados os principais fatores que produziram as mudanças no plano da igualdade de determinados países. Antes, ver-se-á uma tendência à aglutinação por regiões em termos de Gini, mostrando quando e porque houve

\footnotetext{
${ }^{1}$ Piketty, T. Top incomes over the twentieth century, 2013, p. 54

${ }^{2}$ idem (p. 942)
} 
tendências à má distribuição das rendas. Juntamente com essa análise, serão apresentados valores de pobreza e de distribuição de renda por estratificação social para ver, respectivamente, o bem estar do país e sua estrutura socioeconômica.

Nesses termos, finalmente, podemos associar alguns eventos de mudanças econômicas dos mercados aos países e suas situações de igualdade e algumas políticas adotadas pelos Estados para enfrentar, ou não, esses desequilíbrios. Analisar-se-á quanto e de que forma as policies destes influenciaram o nível da concentração de renda e se tentará avaliar o porquê dessa aglutinação regional.

Considerado isso, a pesquisa parte da questão levantada do porquê dos países apresentarem uma tendência ao aumento da desigualdade e, mais importante, por que eles seguem ondas de aumento em períodos parecidos. A partir de algumas observações, se vê que na Europa do leste houve esse aumento entre 1989 e 2000, anos de desmantelamento da URSS, enquanto para a Europa do norte, o período foi de 1980 a 1995, décadas de abertura dos mercados e das privatizações e, finalmente, para a Europa do sul, entre 1990 e 2000, por incluir países de economia fraca que ficaram mais expostos à crise de 1990. De que forma as redefinições do capital mundializado afetaram os países? Como seus governos se comportaram perante essas redefinições e como isso se refletiu nos países? A pergunta principal que será levantada é, portanto: por que motivo as macroregiões da UE apresentam tendências na mudança da desigualdade em períodos iguais?

No próximo capítulo da Parte I, será apresentada a metodologia da pesquisa. Esta segue um campo de ação de cunho crítico marxiano que nos permite pensar em termos materiais a história da Europa como uma história de acumulação e estudar os fenômenos que esta gerou ao ser incentivada de formas diferentes nas diversas regiões e países. Em decorrência disso, depois de fechar a Parte I com um apanhado sobre a relação do Estado com o mercado, na Parte II será inicialmente mostrado, no Capítulo 4, porque é preciso conduzir a análise sobre as desigualdades na Europa de forma multidimensional: depois de apontar os pros e os contra da utilização (isolada) do índice de Gini, será mostrado como o índice 
de polarização das rendas pode dar novas roupagens ao estudo da desigualdade e como isso respeita a ontologia marxiana utilizada.

Entrar-se-á no vivo da pesquisa nos Capítulos 5 e 6 . O Capítulo 5 tem o objetivo de dar uma visão geral por regiões da Europa para poder entender como o capital entrou de formas diferentes em diferentes economias, isto é, como um tipo de Estado comportou-se em relação à entrada e/ou à nova acumulação de capital. No Capítulo 6, finalmente, haverá um quadro mais aprofundado sobre os países que mais apresentaram peculiaridades das áreas às quais eles foram atribuídos pela pesquisa. Tomaram-se dois países por área para fazer uma análise nas variações de suas estruturas sociais e para entender quais foram os fenômenos decorrentes destas que mais produziram desigualdade no sentido estrutural.

Para a Europa central, França e Alemanha apresentam exemplos de intervenção estatal redistributiva e de outras medidas de welfare; na Europa do norte, a Irlanda e a Grã Bretanha representam um tipo de economia que Marx (1867) define "capitalismo clássico", onde o trabalho gera altos valores de mais-valia e a distância entre o top e o bottom é grande e parece em contraste com os níveis de crescimento alcançados por estes países, sobretudo em algumas épocas específicas; para a Europa do leste, os últimos dois países da região que acessaram ao mesmo tempo na União Europeia, Bulgária e Romênia, apresentam um conjunto de indicadores socioeconômicos com níveis baixos, decorrentes da transição de regime que estes sofreram; a Europa do sul será definida de estilo "mediterrâneo" e a análise da estrutura social dos dois países escolhidos, Itália e Grécia, nos mostrará que esse é um tipo peculiar de Estado com lacunas muito grandes na manutenção de "sustentabilidade" em relação ao mercado.

Por fim, as conclusões apontadas no Capítulo 7 têm um valor esclarecedor para começar a formar novos pontos de partida para futuros estudos que tenham a prática marxiana de materialismo histórico como metodologia dominante. 


\section{2. \\ Metodologia}

Para pesquisar como um contexto tão amplo pode ser reconduzido à desigualdade que hoje queremos estudar, entrou-se na abordagem crítica de uma bibliografia de cunho marxiano, visto que o estudo partirá dos pressupostos da mundialização do capital. Nesse esforço, Cox (1981) nos fornece alguma explicação metodológica essencial.

Na fala de Cox (1981), existem dois tipos de abordagens. A da teoria que soluciona problemas, a qual conserva uma característica de fixidez dos papéis dos atores e das relações entre eles, pois, pela própria natureza desta, os problemas das relações internacionais seriam solucionados a partir de um pleno entendimento una tantum atribuível, em seguida, aos demais problemas.

Seguindo a linha de raciocínio desta abordagem metodológica, no plano europeu existem os Estados membros, cada um dos quais com próprios interesses milenares (ou, então, que remetem a uma antiga raiz), atores internos aos estados que são os que incorporam sua essência e, sobretudo, há ganhos e perdas bem delineados segundo uma explicação do gênero "se Y e Z acontecem é somente porque X sempre foi assim".

$\mathrm{Na}$ busca de uma resposta mais satisfatória, fez-se necessário transcender esta metodologia que, como o próprio Cox (1981) admite, busca uma verdade que se torna obsoleta e pouco fiel às reconfigurações do quadro internacional.

Portanto, uma segunda visão sobre as relações internacionais seria estudada através da "teoria crítica" rejeitando como ponto de partida a hipótese de que os atores podem ser cristalizados e estudados completamente, prevendo assim o comportamento destes. $\mathrm{Na}$ "teoria crítica", existe uma ontologia fluida que acompanha dinamicamente o devir dos atores, no constante trançar das próprias existências e dos próprios significados. Com essa base metodológica, a União Europeia seria não somente explicada pela formação estatal, intraestatal e interestatal, com origem no Estado Nação e tendo uma estrutura inequívoca, mas admitiria como ponto de partida a hipótese de que todos os papéis dos atores e 
todas as relações entre eles estão em contínua definição, tanto é que os eventos de lutas, expressão, determinação e deslocamento caracterizam estes mais que (ou, pelo menos, tanto quanto) o pertencer à própria realidade nacional. A equação começa a ter $n$ variáveis: "se $Z$ aconteceu décadas atrás foi por essas $n$ razões, se aconteceu ontem foi por essas $n^{1}$ razões, se acontece hoje talvez seja devido às $n^{3}$ razões, se acontecer amanhã talvez será pela presença dessas $n^{2}$ razões, etc.”

Delineando mais o caminho metodológico a ser seguido por essa pesquisa, foi considerado mais apropriado um olhar marxiano (na divisão de Cox (1981), marxista) do ponto de vista de uma análise materialista histórica, que auxilie na compreensão das ações dos atores. Em particular aquela dimensão vertical que os atores do bottom, envolvidos, assim como o sistema inteiro, com relações de dominação e subordinação, projetam superiormente formando relações novas. Dessa forma, a teoria crítica restabelece:

1. an awarness that action is never absolutely free but takes place within a framework for action wich constitutes its problematic. Critical theory would start with this framework, which means starting with historical enquiry or an appreciation of the human experience that gives rise to the need for theory;

2. a realisation that not only action but also theory is shaped by the problematic. Critical theory is conscious of its own relativity but through this consciousness can achieve a broader time-perspective and become less relative than problem-solving theory. It knows that the task of theorising can never be finished in an enclosed system but must continually be begun anew;

3. the framework for action changes over time and a principal goal of critical theory is to understand these changes;

4. this framework has the form of an historical structure, a particular combination of thought patterns, material condition and human institutions which has a certain coherence among its elements. These structures do not determine people's actions in any mechanical sense but constitute the context of habits, pressures, expectations and constraints within which action takes place;

5. the framework within which action takes place is to be viewed, not from the top in terms of the requisites for its equilibrium or reproduction (which would quickly lead back to problem-solving), but rather from the bottom or from outside in terms of the conflicts which arise within it and open the possibility of its transformation. ${ }^{3}$

Os pontos escalados por Cox (1981) resumem em pleno a ontologia da visão crítica. Uma atenção particular dá-se para as características descritas nos últimos dois, pois o espaço europeu tem essa combinação de condição material e

\footnotetext{
${ }^{3} \operatorname{Cox}(1981: 135)$
} 
instituições humanas que tem uma certa coerência entre seus elementos ${ }^{4}$; Marx, em sua análise do capital com origem na Europa, já estava preocupado em marcar que:

\begin{abstract}
"However, capital is not a thing, but rather a definite social production relation, belonging to a definite historical formation of society, which is manifested in a thing and lends this thing a specific social character. Capital is not the sum of the material and produced means of production. Capital is rather the means of production transformed into capital, which in themselves are no more capital than gold or silver in itself is money. It is the means of production monopolised by a certain section of society, confronting living labour-power as products and working conditions rendered independent of this very labour-power, which are personified through this antithesis in capital."
\end{abstract}

Dessa forma, o capital, que segundo uma visão neorrealista é sinônimo de acumulação e, portanto, o meio com o qual os estados medem seus ganhos e perdas no cenário mundial, é para Marx (1894) uma relação definida de produção social, marcando seu aspecto da acumulação apenas como um dos meios dualistas de auto-fomento/deterioração que ele possui, isto é, uma das suas contradições intrínsecas ${ }^{6}$. Ela é pré-constituída, porém em constante reconfiguração.

Outro autor, Cocks (1980), propondo também uma análise histórica da Europa para tentar visualizar todas as fases que foram perpassadas pelo capitalismo, começa por dois momentos. O primeiro dos dois que interessam à pesquisa, começa no segundo pós guerra, quando:

[...]the enduring connection between economic growth and legitimation has taken a new twist. With the emergence of the full-fledged welfare state, the optimal legitimating format is one in which, first, the political populace as a whole accepts the objectives and interests of the dominant economic class as its own \{e.g., the efficacy of production for profit, free labor, competition, private property); second, political problems are transformed into ostensibly nonpolitical,

\footnotetext{
${ }^{4}$ Isso será explorado à frente.

${ }^{5}$ Marx (1894: III,48)

${ }^{6}$ É difícil, nesses termos, considerar, conforme Cox (1981) faz, que "O Capital" seria meramente uma demonstração empírica e, portanto, contaria com uma visão totalmente ahistórica. Mesmo que, efetivamente, Marx (1848) use dados para mostrar, entre outras coisas, a queda tendencial da taxa de lucro, e que ele assuma a mudança de um modo de produção para um outro como a ruptura essencial pour elle même, ele não deixa de pontualizar em modo exacerbado que o valor é a forma dominante de uma relação econômica, social e política e que sua representação na dominação através da extração de mais-valia é o ponto fraco que necessita ser o alvo para uma mudança social.
} 
technical, administrative issues, so that the essentially political questions of power and inequality are expunged effectively from political discourse. ${ }^{7}$

$\mathrm{Na}$ época, o discurso do bem-estar estava desligado da preocupação com a igualdade: sendo uma sociedade "a soma zero", se todos vivessem bem, ninguém "sentia" benefícios, pois o ganho relativo de um era ligado à perda de outro.

Dessa forma, uma primeira tentativa de aproximação à integração seria justificada pela própria natureza da acumulação capitalista, isto é, pela necessidade de ter a cada momento aqueles aspectos tais como exército de reserva, estratificação social e desigualdade, novos recursos, etc. que fornecem as bases para sua afirmação.

Segundo Cocks (1980) outra justificativa pode ter sido a simples vontade de se opor à hegemonia norte-americana em um momento em que o capital europeu estava à mercê desta, já que outras uniões como a Zollverein alemã de 1848 não eram suficientemente abrangentes.

Uma terceira hipótese pode ser encontrada na necessidade de dar novas roupagens às relações coloniais ainda importantes para o crescimento dos países. Isso pode ser percebido através das várias convenções que surgiram como parcerias entre os países europeus e os da África, Pacífico, Caribe etc. tal como a Convenção de Lomé de 1975 que depois de 15 anos foi revogada como sendo inaceitável pela OCDE.

Se a segunda e terceira hipóteses parecem ser verdadeiras, pelo menos de forma geral, a primeira é sem dúvida a que mais fornece elementos válidos à pesquisa, pois está na própria análise da acumulação do capital europeu e norte-americano a base metodológica deste trabalho.

Mesmo que uma tendência forte às variações de igualdade tenha sido percebida no estudo dos índices de igualdade em áreas macro-regionais europeias, não podemos deixar de ressaltar que são os próprios Estados os objetos principais da pesquisa; é através destes que o desenvolvimento da análise toma forma pois

\footnotetext{
${ }^{7}$ BONOMI apud COCKS, 1980: 9
} 
foram eles que sempre garantiram a priorização da acumulação e do crescimento capitalista e foram eles que propiciaram em todas as épocas, com meios diferentes, a proteção desse sistema.

A emergência do Estado, considerado como Estado Nação, coincidiu com a emergência das classes sociais e as lutas de classe na transição de uma forma primitiva até formas mais avançadas de produção. Nessas novas formas de produção, criou-se um "excedente” que já era de monopólio de certas classes dominantes; neste processo, o Estado começou a ter um papel de mantenedor do "bem-estar" e do privilégio dessas classes. Isso pode ter acontecido em detrimento dos direitos das classes trabalhadoras. Em Marx (1959), achamos a crítica que faz à sociedade civil perante o Estado que, em suas palavras, é o "Estado burguês":

"O Estado é um órgão especial que surge em certo momento da evolução histórica da humanidade, e que está condenado a desaparecer no decurso da mesma evolução. Nasceu da divisão da sociedade em classes e desaparecerá no momento em que desaparecer esta divisão. Nasceu como instrumento nas mãos da classe dominante, com o fim de manter o domínio desta classe sobre a sociedade, e desaparecerá quando o domínio desta classe desaparecer"

$\mathrm{e}$

"A minha investigação desembocou no resultado de que relações jurídicas, tal como formas de Estado, não podem ser compreendidas a partir de si mesmas nem a partir do chamado desenvolvimento geral do espírito humano, mas enraízam-se, isso sim, nas relações materiais da vida, cuja totalidade Hegel, na esteira dos ingleses e franceses do século XVIII, resume sob o nome de 'sociedade civil', e de que a anatomia da sociedade civil se teria de procurar, porém, na economia política." 8

Com efeito, a afirmação desse sistema fez com que nascessem as uniões dos trabalhadores e as demais organizações trabalhistas que tentaram antagonizar o protagonismo da classe privilegiada. Isso gerou confrontações violentas em diversas ocasiões e revelou-se, logo, uma ferramenta que o Estado precisava absorver tornando-se garante dos direitos da classe trabalhadora e empoderandose ulteriormente com os instrumentos desta (Berberoglu, 2005)

"Sanctioning and enforcing laws to protect the rights of the new property owners and disciplining labor to maintain a wage system that generated profits for the

\footnotetext{
${ }^{8}$ Marx, K. Para a Crítica da Economia Política, 1859, prefácio.
} 
wealthy few, the capitalist state became the instrument of capital and its political rule over society."

Os Estados, todavia, não representam um conjunto fechado: se a pesquisa visa, com efeito, buscar uma resposta ao aumento de desigualdade intraregional e interregional, na área europeia pós-processos de mudança do sistema, isto prova que aqui não está tomando-se emprestado um ator para delegar-lhe o papel de garantidor da acumulação sem o envolver nos demais processos; mesmo que muitos fatores estejam co-relacionados entre eles, e nunca possamos provar quanto um fator é isolado em relação aos demais para definir essas variações de igualdade, devemos delinear antes de tudo as diferenças que intercorrem entre esses Estados. Não poderemos mais, portanto, afirmar nessa chave de leitura que "os Estados" tem algum interesse específico.

Foi analisado, com esse propósito, o estudo em macro-regiões que, mesmo se simplificadas, auxiliam no objetivo de mostrar como nunca houve um consenso sobre algumas políticas da União (ou pré-União) e que foram justamente os interesses das regiões mais fortes (com capital mais aprimorado) que prevaleceram não somente na hora de implementar uma integração mas, sobretudo, de como implementá-la.

Primeiro de tudo, deve ser estudado quanto e como o interesse do capital norteamericano entrou na história dos demais países. A importância desta abordagem pode ser encontrada nos textos de Mandel (1967), Torres (2013), Helleiner (1994), Panitch e Gindin (2004), Wood (2003) entre outros. Mandel (1967) lê na entrada do capital EUA, com suas formas de fusões, compras, etc., a resposta dos primeiros seis países que criaram o mercado comum nos moldes do Zollverein:

"By itself, the Common Market is nothing but a means of facilitating trade expansion, and its impact on the national economies of the six member countries has still not yet outgrown these limits." 10

O autor explica que até quando essas potências europeias defenderam os interesses de um capital estrangeiro, se viam relegadas a um papel "semicolonial", não tendo, esses Estados, interesses internos (do capital nacional) a

${ }^{9}$ idem, p.541

${ }^{10}$ Mandel (1967: 30) 
serem protegidos. Seria a necessidade de dar um pulo para frente e voltar a ter controle sobre o interesse próprio que teria desencadeado o processo de criação do Mercado Comum.

"[...] the growth of capital interpenetration inside the Common Market, the appearance of large amalgamated banking and industrial units which are not mainly the property of any national capitalist class, represent the material infrastructure for the emergence of supra-national state-power organs in the Common Market."

Não pode se esquecer que, mesmo através da criação do Mercado Único e de todas as infraestruturas próprias deste, quem era o direto responsável do próprio capital era o Estado Nação. No que concerne essa relação Estado/Mercado, importante será ver o quanto foram mudando as relações entre esses atores, mesmo que o primeiro, concebido com essa prerrogativa de Estado Nação, ainda exerça o papel de garantidor do bom funcionamento do próprio capital perante o mercado externo. Wood (2003) explica que:

\begin{abstract}
"Na verdade, o capitalismo mais do que qualquer outra forma social requer, para a efetivação das suas transações diárias, ordem e regularidade previsíveis, um elaborado aparato legal e administrativo e uma infraestrutura complexa. [...] Apenas o Estado territorial tem sido capaz de proporcionar estas condições. É difícil imaginar qualquer forma de "governo global" capaz de prover a ordem administrativa e legal da vida diária de que o capitalismo necessita para conduzir os seus negócios, ou a coerção necessária para a manutenção do sistema de propriedade (ou da falta de propriedade) numa situação de gritante desigualdade. Os Estados territoriais munidos de instrumentos de administração e coerção locais ainda são a única opção viável. Ademais, o capital global se beneficia do desenvolvimento desigual e da diferenciação existente nas diversas economias do mundo, que proporcionam fontes baratas de trabalho e de recursos, enquanto ao mesmo tempo controlam a mobilidade da mão de obra. Esta fragmentação das economias também é controlada pelos Estados locais. Para exercer o seu alcance global, o capitalismo precisa dos Estados locais que mantêm as condições básicas para as suas operações. O mundo de hoje é mais do que nunca um mundo de Estados-nação; e a forma política do capitalismo global não é um Estado global e sim um sistema global de múltiplos Estados locais. Assim sendo, a separação dos poderes econômicos e políticos sinaliza a existência de uma disparidade crescente entre o alcance global do capital e os instrumentos locais de administração e implementação de que ele ainda necessita e não que o capitalismo global superou a necessidade da existência do Estado territorial."12
\end{abstract}

\footnotetext{
11 idem p. 31

${ }^{12}$ Wood (2003: 46)
} 
Não podemos, portanto, contemplar a ideia segundo a qual a mundialização do capital preveja a quebra das fronteiras políticas (alcançando, como muitos nomeiam, a "globalização"), pois a tendência deste é de perpassar as barreiras sem jamais as quebrar. O capital se fortalece somente com os interesses nacionais de crescimento e acumulação.

O fim do padrão-ouro foi impulsionado justamente pela ineficiência que esse antigo sistema tinha para garantir o tratamento igual do capital estrangeiro juntamente com o capital nacional, o que já na época vinha se considerando como um pré-requisito fundamental para a mundialização do capital. Na afirmação do novo sistema pós-Bretton Woods, os EUA assumiram o papel de líder mundial enquanto os outros Estados tinham mais flexibilidade na atuação no mercado internacional; isso foi o primeiro passo para uma mudança sistêmica completa com a internacionalização do comércio e de IDE e a restauração do mercado financeiro global, que levaram à perda de controle dos capitais e à vulnerabilidade das taxas de câmbio fixas ${ }^{13}$.

Deste momento em diante, todos os mercados começaram a ser interligados e, mesmo que aquela importante figura do Estado Nação fosse central, todas as mudanças que interessavam o capital estrangeiro começaram a afetar a realidade nacional.

Depois que todos esses atores tiveram uma fortíssima interconexão, começaram os problemas sistêmicos globais. O déficit comercial dos EUA começou a aumentar muito até o ponto em que, em 1971, o presidente Nixon anunciou o fim da conversibilidade com o dólar. A moeda passou por uma repentina desvalorização que ajudou os EUA a amenizar aquele déficit; porém, a situação começou a piorar novamente devido à fuga maciça de capitais do país. Assim, em 1979, o Fed guiado por Volcker acionou uma série de políticas de ajuste:

"The Federal Reserve's determination to establish internal economic discipline by allowing interest rates to rise to historically unprecedented levels led to the vital restructuring of labour and industry and brought the confidence that the money markets and central bankers were looking for. Along with the more general

\footnotetext{
${ }^{13}$ Panitch e Gindin (2004: 18)
} 
neoliberal policies that evolved into a relatively coherent capitalist policy paradigm through the eighties, the new state-reinforced strength of finance set the stage for what came to be popularly known as 'globalization' - the accelerated drive to a seamless world of capital accumulation." 14

No início da década, conforme explica Torres (2013), os norte-americanos começaram a privilegiar os interesses do capital privado e da especulação de curto prazo de forma que "em um sistema de câmbio flutuante sem a mediação de nenhum mecanismo internacional extra-mercado, a pressão dos capitais privados para a valorização de suas moedas levaria os governos estrangeiros a serem obrigados a ajustar suas economias."15. Dessa forma, na Europa começou-se a pensar, em 1979, na união monetária para contrabalançar os problemas apresentados pelo dólar.

Do lado da União Europeia, Panitch e Gindin (2004) afirmam ainda que, desde seus primórdios, esta nunca se contrapôs ao projeto norte-americano, tanto que o capital americano nunca entrou em conflito com o capital europeu, mesmo dentro das próprias fronteiras da União.

\begin{abstract}
"What it has accomplished in terms of free trade and capital mobility within its own region has fitted, rather than challenged, the American-led 'new form of social rule' that neoliberalism represents. And what it has accomplished in terms of the integration of European capital markets has not only involved the greater penetration of American investment banking and its principle of 'shareholder value' inside Europe, but has, as John Grahl has shown, been 'based on the deregulation and internationalization of the US financial system" "16
\end{abstract}

Tudo faz parte do que, segundo a escola marxista, é a coexistência entre mercado e Estado através da moeda e seus mútuos interesses. Todos os poderes continuam sendo incorporados pelo Estado e ele continuará a prevalecer nas decisões que afetam o panorama interno. Externamente, o mercado faz com que o capital circule entre os vários países favorecendo seu crescimento. De fato, quando se fala em globalização, se deveria esclarecer que a pertinência da palavra se refere ao espaço financeiro, isto é, ao processo de movimentação e reprodução do capital; sua preservação ainda é, como foi explicado, de interesse nacional. Isso bem se resume nas palavras de Torres (2013), quando o autor aponta que:

\footnotetext{
${ }^{14}$ idem (2004: 21)

15 Torres $(2013: 6)$

16 idem (2004: 24)
} 
"Em meados de 1980, as principais economias já haviam completado a liberalização das suas contas de capital, permitindo a formação de um mercado financeiro efetivamente globalizado. [...] Todo esse desenvolvimento não teria sido possível sem o consentimento, a parceria, os estímulos e as garantias dadas aos mercados financeiros pelos governos das principais nações." 17

A importância do Estado Nação, a mundialização do capital e a relação de ambos norteiam o desenvolvimento da pesquisa.

${ }^{17}$ Torres (2013: 21,23) 


\section{3.}

\section{O Papel do Estado e do Mercado}

Existem muitas teorias para explicar minuciosamente qual é a função do Estado e a do mercado e como essa relação evoluiu ao longo do tempo. Embora o Estado represente o lado político ao mesmo tempo que o mercado representa o econômico, chegou o momento de frisar a importância da interconexão dos dois e da economia com a política. É importante entender bem essa relação pois " $O$ Estado influencia profundamente o resultado das atividades do mercado ao determinar a natureza e a distribuição dos direitos de propriedade, assim como as regras que regulam a conduta econômica"18.

Entender de que modo acontece a interligação entre os Estados e entre os diversos mercados é prioritário para o estudo da economia política e para fundamentar os presupostos dessa pesquisa, pois se essas relações geram ou não um ambiente propício e de que forma isso acontece são os pontos nos quais as diversas escolas teóricas não convergem.

Primeiro, os liberais que acreditam em um mercado internacional onde cada Estado teria uma vantagem comparativa na divisão internacional do trabalho pouco tem em comum com os nacionalistas que, ao contrário, conforme o nome sugere, depositam todas as tarefas mais importantes para o ordenamento da vida, da sociedade, do crescimento e, por fim, do mercado, nas mãos do Estado.

Em segundo lugar, os autores com viés marxista explicam essa relação como imperialista. O capitalismo, pois, teria em sua natureza implícita relações de dominação e subordinação que são as principais causas da aparição do mercado mundializado.

A relevância dos diversos pontos de partida, claramente, encontra-se em outras suposições sobre as influências mútuas entre Estado e mercado e se determinadas mudanças no primeiro afetam o segundo, ou vice-versa, ou se isso não tem nenhuma relação. O mercado, de toda forma, deve ser entendido mais em

\footnotetext{
${ }^{18}$ Gerth e Mills, 1946 apud Gilpin, 1987.
} 
profundidade para fazer qualquer tipo de estudo de economia política. Sua existência implica uma visão muito mais ampla e que abrange decisões estatais, condições de trabalho, evolução histórica, exclusão regional e qualquer outro aspecto ligado ao contexto macro e micro.

Para começar, temos que esclarecer algumas diferenças tanto paradigmáticas quanto ideológicas. Se, por um lado, Karl Marx identificava o sistema capitalista como aquele sistema com apropriação dos meios de produção e trabalho assalariado, era no mercado que ele via, ao mesmo tempo, a realização de todas as contradições do sistema: a produção de mais-valia, a queda marginal da taxa de lucro, a possibilidade de acumulação, a concorrência, etc. É difícil, portanto, imaginar um capitalismo sem mercado. Mesmo as hipóteses de capitalismo de Estado são transitórias, pois, conforme o próprio Marx sempre afirmou, o capitalismo precisa cada vez de mais mercado para evoluir.

As forças que movem e motivam os mercados são, assim, muito constrangedoras para as sociedades. À medida que uma especialização, baseada nas vantagens comparativas (do economista David Ricardo e suas teorias mais complexas como a de Heckscher-Ohlin), acontece no nível mundial, alguns países atuam em uma relação de subordinação em relação a outros, pois, como se pode imaginar, quando um país é especializado em produtos primários, commodities ou produtos com baixo valor agregado, possui mão-de-obra mais barata e pouco qualificada. Se, por um lado, podemos ver isso em uma análise inter-países, o que percebemos hoje é que voltou-se a ter uma disparidade de salários e condições de sobrevivência assimétricas dentro dos próprios países e, no caso analisado aqui da Europa, podemos ver como isso acontece em uma escala maior apresentando uma aglutinação regional, dependendo do histórico do mercado que se instaurou nas diversas regiões.

"Em suma, os mercados constituem uma força poderosa de transformação social e política e provocam reações igualmente importantes, à medida que as sociedades tentam se proteger contra as forças que desencadeiam (Polanyi, 1957). Portanto, não há Estado, por mais liberal, que permita a manifestação plena e livre das forças do mercado. Outra consequência da economia de mercado é o 
fato de ela afetar significativamente a distribuição de riqueza e de poder entre as sociedades e dentro de cada uma." 19

É este comportamento "constrangedor" do mercado que aqui nos interessa, pois, conforme todos os economistas analisaram com metodologias diferentes, e Gilpin (1987) afirma nas linhas acima mencionadas, a desigualdade de uma dada população é intrinsecamente relacionada à efetivação, à mise-en-scène, dos pródromos que regem seu funcionamento. Como isso se verifica e com que consequências, é o questionamento mais interessante que pode chamar a atenção de um pesquisador de economia política. Se, por um lado, na presente pesquisa faz-se uma tentativa de indagação dessas problemáticas, mesmo não podendo responder de forma clara considerada a complexidade do sistema no qual os atores interagem, ao menos propõe-se uma linha a ser seguida que não aceita respostas condicionais do mainstream, tanto o atual quanto o de algumas décadas atrás.

A introdução de um sistema de mercado na sociedade, conforme Marx afirmava, acarreta profundíssimas transformações dentro daquela sociedade. Appleby (1978) diz a respeito:

\footnotetext{
"O passo crítico no estabelecimento de um momento do mercado é a alienação da terra e do trabalho. Quando esses componentes fundamentais da existência social sentem a influência do mecanismo dos preços, a direção social transfere-se para os determinantes econômicos" ${ }^{\prime 20}$.
}

Dizer que "...a direção social transfere-se para os determinantes econômicos" significa que suas decisões, seu uso, sua própria ontologia, mudam. Temos assim uma expropriação do trabalho (através do salário). No caso dos países socialistas, Gilpin (1987) explica que o sistema se baseia no intercâmbio que rege uma economia planejada, isto é, uma economia na qual o Estado controla as trocas no mercado.

O controle do mercado é o foco dos maiores debates econômicos do último século. Quanto maior controle do mercado por parte do Estado, mais os

\footnotetext{
${ }^{19}$ Gilpin (1987 : 40)

${ }^{20}$ Appleby apud Gilpin, 1987: 36.
} 
portadores de interesses que atuam no alto escalão econômico se ressentem desse freio.

À medida que o mercado exige tecnologias cada vez mais avançadas para reivindicar seus princípios básicos de concorrência e eficiência, novos segmentos de produção são englobados, os quais mudam a escala do mercado. Nesses termos, acontece uma apropriação dos assim chamados "fatores de produção", tais como força trabalho e terra, que passam a estar sujeitos às leis em vigor no mercado e "quantificadas" e "precificadas" através deste.

Não há de se surpreender que, em uma troca desse tipo, uma vez que o mercado alcança níveis altos de extensão, alguns atores se beneficiam mais em relação aos demais. A concentração de rendas, de riquezas e de bem-estar resulta, dessa forma, bastante nítida quanto mais nítida é a separação de trabalho em um determinado mercado.

A disparidade que vem se manifestar entre os atores é dada de forma sistêmica à própria natureza do sistema capitalista. Porém, de forma a ter um "controle" sobre os fatores de produção e manter altos os níveis de produtividade e crescimento de um mercado (de um País / do sistema inteiro), os diversos governos intercedem de forma incisiva adotando medidas redistributivas, mesmo que isso não signifique uma mudança de facto na igualdade social na estrutura de longo prazo. Assim:

"a tendência resultante é a de que os Estados intervenham nas atividades econômicas para promover os efeitos que os beneficiam e para reduzir os que lhes são prejudiciais" 21 .

Com as interdependências com que os mercados operam nos dias de hoje, novas relações de poder instauram-se entre os diversos países. Ao mesmo tempo em que a maioria dos Estados enfatiza os benefícios dessa interdependência, a igualdade nos próprios países, e entre eles, tende a oscilar gerando resultados muitas vezes nefastos e que abrangem múltiplas esferas da sociedade.

\footnotetext{
${ }^{21}$ Gilpin (1987 : 39)
} 
De que forma o mercado regula a vida da(s) sociedade(s), conforme citado no início do parágrafo, é a questão principal objeto das diversas teorias econômicas e, em última instância, da economia política. O mercado, sem dúvida, tem um efeito muito modelador dos comportamentos, mas nem todos os pesquisadores atribuem a ele um papel decisório.

Muitos destes, os assim chamados na economia "liberais", acreditam em uma naturalidade do mercado e uma simbiose dos atores sociais com ele. Nesse sentido, o papel do Estado deveria ser o mais limitado possível para não interceder em um processo que, se funcionar em um ambiente próprio, levaria a comportamentos satisfatórios para todos. Esse equilíbrio que os liberais procuram estabelecer, então, não contaria com ajustes estatais. O governo entraria no processo uma vez que se verificasse alguma anomalia, de forma geral rara.

Já segundo os nacionalistas, proteções impostas ao funcionamento "anárquico" do mercado preveriam assimetrias de informação, abusos de poder, ilegalidades condicionadas a diversos setores, além de prover uma ampla proteção à sociedade que, nesses termos, não teria condições de gerir esse complexo esquema de funcionamento, por causa de todas as ações que o mercado desenvolve e que não dão informação clara sobre quais seriam seus efeitos. Essa vulnerabilidade justificaria uma série de políticas nacionais voltadas à proteção de seu ambiente indoor.

Por último ${ }^{22}$, a visão marxista enxerga o mercado como o sistema que mudou a estrutura antiga feudal presente nos diversos Estados. Assim, sua existência ligada a essa "inevitabilidade" ocorrida através de um processo natural de transformações sociais e econômicas faz com que seja preciso entrar mais a fundo nessa relação através de uma visão histórica.

A metodologia, apresentada em termos claros, tanto teóricos quanto empíricos, por Marx em 1867, impõe uma nova dialética segundo a qual precisa-se revisar tanto a abordagem dos liberais quanto a dos nacionalistas. Segundo a linha do

\footnotetext{
${ }^{22}$ Na classificação de Gilpin (1987) entre outras.
} 
marxismo, os elementos mais importantes atribuídos ao funcionamento do mercado, a demanda e a oferta, não encontram equilíbrio e isso cria uma desproporcionalidade. Além disso, a acumulação capitalista geraria uma concentração de muito nas mãos de poucos criando uma distribuição desigual das riquezas. A tendência à queda da taxa de lucro, ponto importante da teoria de Marx, mostraria outro ponto fraco do sistema de mercado capitalista, quando a sobreprodução gera tendencialmente uma queda "paradoxal" de lucratividade formando, assim, uma das contradições intrínsecas do capital.

Um estudo recente de um autor supracitado, Piketty (2013), assere que a taxa de lucro do capital, na verdade, aumenta a um ritmo mais rápido que o produto interno, superando este último. Sua metodologia, que formou o esqueleto de uma pesquisa que durou alguns anos, baseia-se no recolhimento de dados sobre a taxa de lucro do capital em diversos países e na comparação destes com a curva do crescimento do PIB nacional daqueles países.

A argumentação de Piketty (2013) tenta se sustentar na assunção de uma desigualdade fundamental pela qual a taxa de lucro do capital $(r)$ seria maior que a taxa de crescimento da economia $(g)$. Isto, em termos econômicos, significa que uma parte da economia (do produto interno) entrará nos lucros do capital. Este surplus será reinvestido no processo e gerará lucros crescentes do capital. 
Gráfico 1a: A proporção capital/rendas, 1870-2100

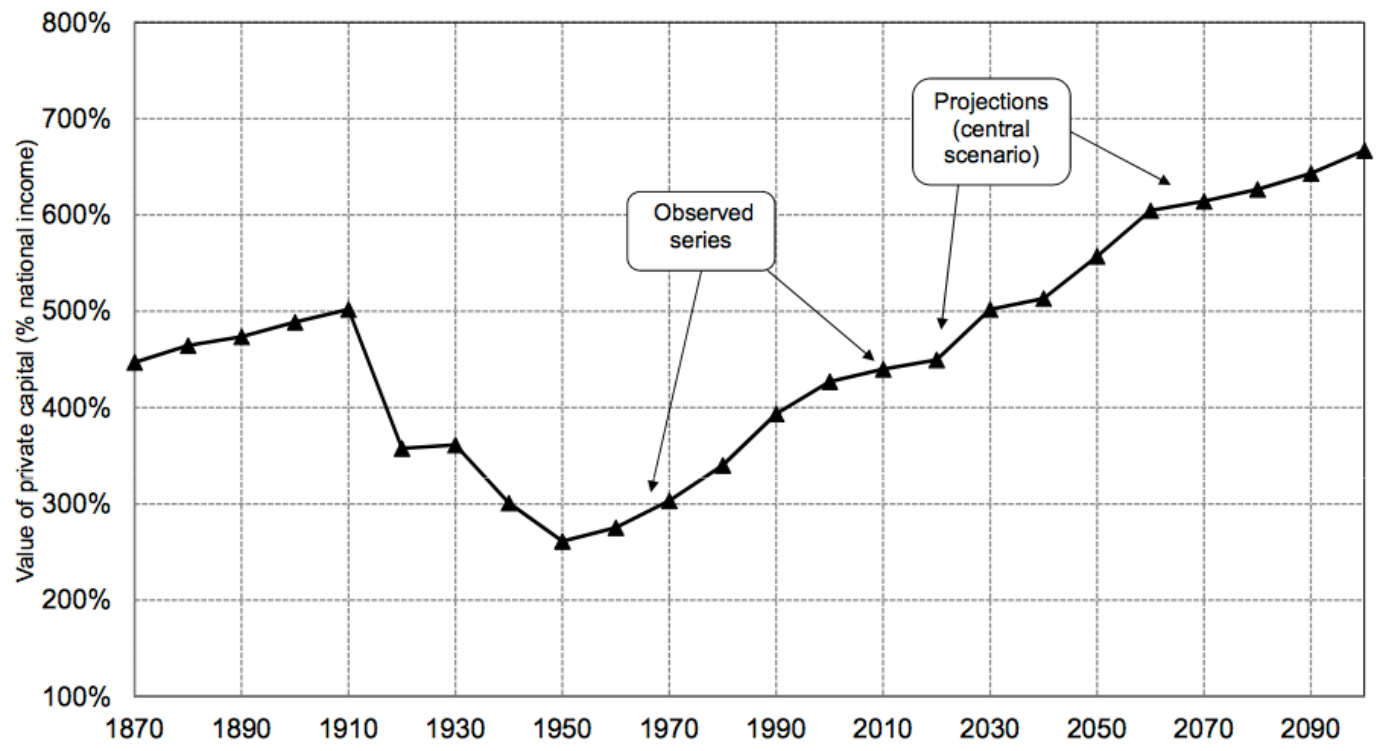

Fonte: Piketty, T. Technical Appendix of the book "Capital in the 21st century". 2014

Os patrimônios herdados, assim, recapitalizam-se de forma multiplicada e mais automática em relação aos de nova criação que dependem do trabalho e da produção. Além disso, se o lucro que deriva do capital é mais concentrado em relação ao que depende do trabalho, e a tendência no longo prazo é a do aumento de $r$ em relação a $g$, haverá um aumento progressivo na desigualdade de distribuição. 
Tabela 1: Desigualdade das rendas totais (trabalho e capital) no tempo e no espaço.
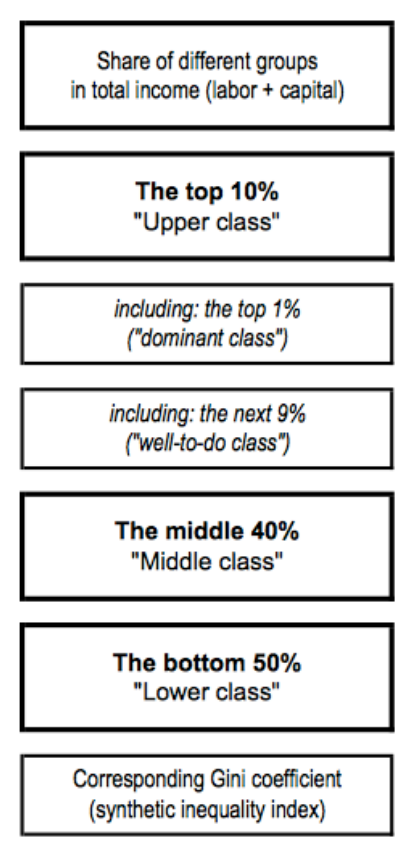
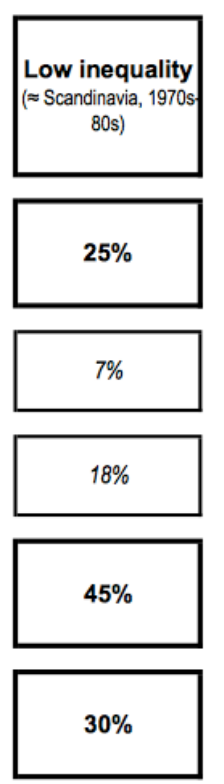

0.26
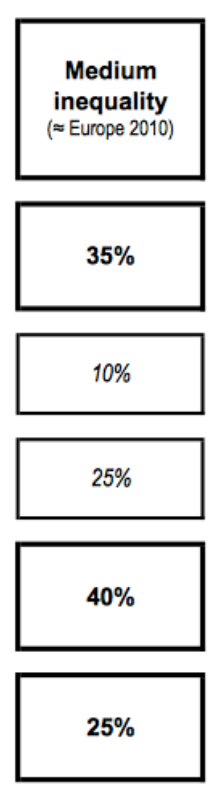

0.36
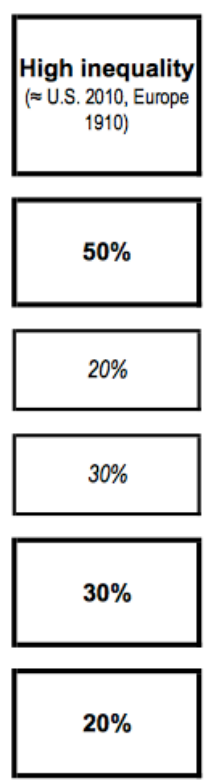

0.49
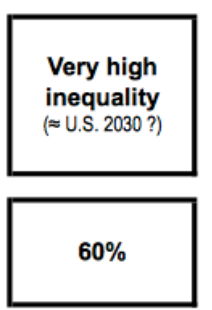

$25 \%$

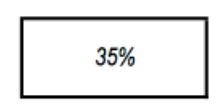

$25 \%$

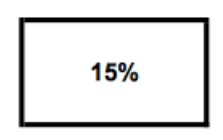

0.58

Fonte: idem

Sendo assim, a recomendação de Piketty (2013) para intervir nessa distribuição progressivamente assimétrica seria uma política redistributiva que restabelecesse uma ordem nas rendas individuais incidindo no lucro do capital e equiparando o crescimento deste ao da economia produtiva.

A análise de Piketty (2013), mesmo que aprofundada empiricamente e, portanto, válida em termos de estudo, deixa porém algumas lacunas nas premissas de sua escrita. Para começar, o capital que ele considera "crescente" em comparação ao produto da economia por trabalho é diferente do conceito de Marx (1867). Por Piketty (2013), este inclui o capital produtivo e o improdutivo, com as riquezas (moveis e imóveis) e todos os patrimônios ${ }^{23}$.

23 "[...] we measure capital directly by using country balance sheets in which we observe the actual market value of most types of assets: real estate, equities (which capture the market value of corporations), bonds, and so on. We are interested in what non-human private capital is worth for households and in what public capital would be worth if privatized." Piketty, 2014 : 6-7 
Já na retórica marxiana vemos um significado diferente que, por outro lado, parece atender mais a um estudo completo. A retorica de Marx (1867), conforme foi evidenciado, prevê uma leitura materialista histórica e considera o capital como um processo (o de acumulação através da extração de mais-valia) e não de um produto finito. Nesses termos, não faria muito sentido avaliar uma tendência ao aumento dos patrimônios juntamente com o capital produtivo pois confundiria na hora de se pensar a evolução do próprio capital. Se considerarmos a acessão marxiana, podemos fazer uso dos dados que o próprio Piketty (2013) coletou, extrair o capital produtivo (relevando o improdutivo) e ver que a conclusão de Marx (1867) sobre a queda tendencial da taxa de lucro ainda seria válida ${ }^{24}$. No exemplo de Piketty (2013) do capital francês, por exemplo, podemos observar isso.

Gráfico 1b: Capital na França, 1700-2010

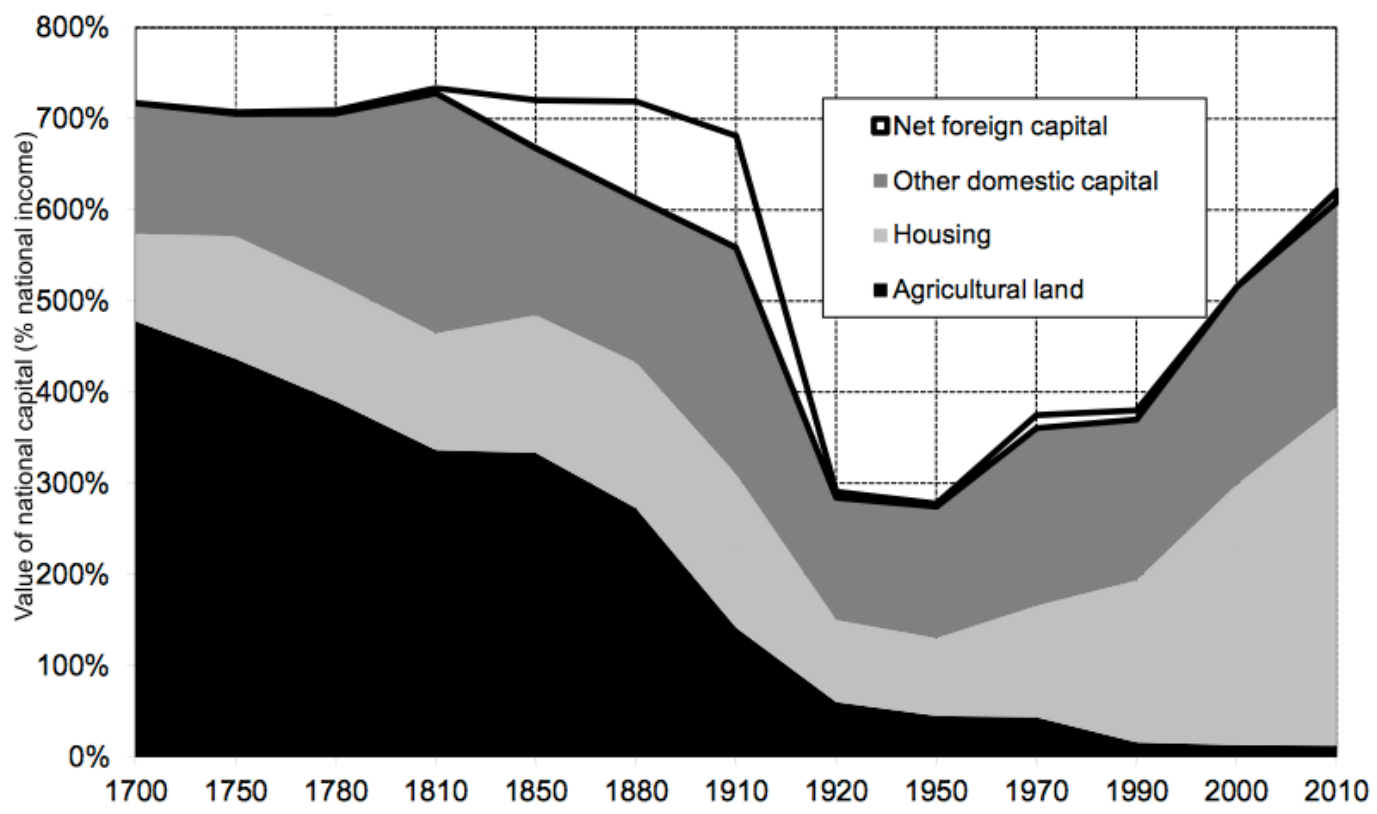

Fonte: idem

\footnotetext{
${ }^{24}$ Maito, E. E. Piketty against Piketty: the tendency of the rate of profit to fall in United Kingdom and Germany since XIX century confirmed by Piketty's data, 2014.
} 
Conforme os próprios dados de Piketty (2013) nos revelam, a taxa de lucro do capital produtivo é declinante. Os elementos que contribuem com o aumento da parcela total da taxa são os patrimônios e toda a parte improdutiva do capital ${ }^{25}$.

Há ainda uma nova consideração a ser feita decorrente dessa premissa: não seria o aumento da taxa de lucro do capital em relação ao PIB a gerar um aumento na desigualdade, mas uma diminuição deste, pois, com lucros marginais cada vez menores, o capital deveria reestabelecer uma margem de lucro que, como visto, é extraída da mais-valia (do trabalho não remunerado) e continua sustentando a produção e os lucros dos capitalistas.

Se, por um lado, Piketty (2013) tornar-se-á útil no momento de estabelecer termos comparativos da concentração de renda de determinados países ${ }^{26}$, é melhor aqui frisar essas lacunas que se abrem se, como é o caso da presente pesquisa, se deseja conduzir um trabalho metodológico que preveja uma análise materialista histórica nos moldes marxianos do capital entendido como processo e jamais como produto $^{27}$.

Marx (1867) dedicou sua obra maior ao estudo deste último e de seu funcionamento. No tocante ao papel do Estado e do mercado e sua relação, Marx (1867) afirma que o mercado interno tende à expansão pois precisa alcançar o mesmo ritmo de crescimento da produtividade (nunca se igualam). Ao fazer isso, abre suas fronteiras e se torna mundializado, mas o Estado permanece sempre o ator que promove seu desenvolvimento. $\mathrm{Na}$ expansão, há uma desagregação parcial do Estado Nação que relega às instituições internacionais o poder de organização.

\footnotetext{
${ }^{25}$ Para falar nos mesmos termos de Marx (1867), seria aquela riqueza que não tem uma parte intrinseca que depende do trabalho e da extração de sua mais-valia para se multiplicar e perpetrar sua acumulação.

${ }^{26}$ Mais adiante veremos como esse estudo pode ser útil para avaliar a mudança na estrutura socioeconômica da França e de outros países.

${ }^{27}$ A fala de Piketty $(2012 ; 2013 ; 2014)$ se apoia na afirmação que existem dois modos para se tornar ricos: através do próprio trabalho e/ou ganhando uma herança. Uma terceira - e única afirmação admitida na presente pesquisa - seria a de Marx (1867) que, parafraseando, definiria a extração de mais-valia do trabalho dos outros como único modo para se tornar rico.
} 
Dessa forma, o mundo teria uma hierarquia definida de estados (e regiões) que fazem parte do mercado mundializado, isto é, da evolução do mercado capitalista. A leitura de Marx interessa à pesquisa pois, de forma muito clara e direta, atribui, no caso da Europa, a definição de uma ordem hierárquica (que existe de facto) ao mercado mundial/mundializado.

Na visão geral de Marx, alguns como Braudel (1985) e Wallerstein (1982) tentaram ler em uma chave geográfica o mercado mundial, dando a essa hierarquia uma forma binomial de contraste Norte vs. Sul, Centro vs. Periferia, etc. Parece, porém, carecer de perspectiva histórico-materialista, além de metodológica, o trabalho desses pesquisadores sistema-mundistas, pois estariam, dessa forma, omitindo uma relação hierárquica mundial que existe desde sempre e que é definida pelas lutas de classe.

A visão do sistema-mundo, portanto, seria mais propensa a olhar para os Estados como um corpo único, sem ver que, de fato, é do lado interno do Estado que vemos quais são as condicionalidades e os efeitos do mercado capitalista. A hierarquia citada, e que é analisada na pesquisa, procura ver o quanto a mundialização do capital incidiu na polarização social das macro-regiões da Europa, permanecendo focada na desigualdade interna aos Estados de cada região. Ao fazer isso, olhar para o papel do(s) Estado(s) e para as decisões tomadas no último século, ajudará a ver que tipo de relação as diversas regiões da Europa tiveram (e tem) com o mercado e como a igualdade social mudou e se associa a esses fenômenos. 
4.

\section{A desigualdade intra-países e as tendências regionais}

\subsection{A desigualdade e a distribuição de renda}

Pelos motivos que foram explicitados, a teoria crítica norteará os métodos utilizados na pesquisa de forma a observar com um perímetro mais abrangente os fenômenos que interessaram a área estudada durante as redefinições econômicopolítico- sociais ao longo do último século.

O interesse pelas desigualdades remonta ao pós-guerra, cuja literatura conta com o importante trabalho de Kuznets sobre a relação entre desenvolvimento econômico e desigualdades. A hipótese de Kuznets (1967) segundo a qual existe uma relação em U-invertido entre crescimento e igualdade interna ao país exerceu uma fortíssima influência, tanto é que vários autores hodiernos a consideram ainda uma lei fundamental da economia. Durante a década de 1970 esse tipo de estudo obteve muitos seguidores na academia, tanto que foram muitos os que previam uma diminuição da desigualdade entre os países industrializados.

A corrente que acompanhou a década seguinte fez forte contraste com esse tipo de estudo, pois ela considera duas novas constantes: a primeira é a de que começou a observar-se um leve aumento nas desigualdades. A década de 1980, como se sabe, é caracterizada por um aumento das desigualdades ao contrário do esperado (Atkinson, 1996). De outro lado, não parecia existir uma relação sistêmica universal entre crescimento e desigualdade, mas, ao em vez disso, um conjunto de trajetórias diversificadas respondendo a uma série de mecanismos nacionais específicos.

Dessa forma, a partir dos anos 1990, o estudo sobre desigualdade e seus determinantes começa a ter mais espessura entre os analistas. Em particular, no momento em que as trocas internacionais começam a aumentar significativamente, os pesquisadores se perguntaram em que medida a mundialização impactava a distribuição de renda. 
Os economistas começaram, então, a ter mais preocupações com o impacto distributivo das políticas de liberalização comercial preconizadas pelas instituições de Bretton Woods depois dos anos de 1980 para estimular o crescimento econômico. Grande parte dos trabalhos empíricos estudaram a evolução das desigualdades no momento pós-liberalização. Uma fração destes propôs-se a analisar a questão da dinâmica das desigualdades nos salários ou, mais em geral, do rendimento dos fatores de produção.

$\mathrm{Na}$ raiz das desigualdades há o processo de distribuição de rendas que pode ser resumido em três parcelas: a que vai para os empregos em forma de salários, a que vai para as empresas como dividendos e a que vai para as finanças como juros e rendas. A quantidade e a qualidade do emprego e o nível dos salários estabelecem a parte de produto nacional de contribuição pelos empregos. O tamanho dos dividendos depende do capital investido nas empresas e de seu sucesso no processo de acumulação. As rendas refletem os tamanhos dos patrimônios, financeiros e de imóveis, e as lógicas especulativas que alimentam seu crescimento.

Mas, entre as rendas e o consumo destas existem três passagens: o efeito da inflação, que transforma as rendas nominais em rendas reais; o efeito dos impostos e das transferências públicas, que transformam as rendas brutas em rendas líquidas; o efeito das famílias, nas quais se agregam rendas de natureza variada, dos quais resultam padrões de vida diversos. Depois dessas passagens, pode-se calcular as rendas pessoais e chegar à distribuição individual de renda, a qual documenta a efetiva posição de ricos e pobres.

Igualmente importante é considerada a distribuição do estoque de riqueza; esta amplia-se todo ano com poupanças e investimentos (ou pode se reduzir), mas pode também crescer através de ganhos por capital (capital gains), aumentos de valores do patrimônio financeiro ou de imóveis ligado ao andamento dos mercados destes bens. 
Entre vários métodos que poderiam ser utilizados para identificar a tendência da igualdade/desigualdade na área da União Europeia, alguns dos mais utilizados da literatura foram considerados, aqui, somente enquanto situações pré-determinadas. Primeiros entre eles, a renda per capita e a taxa de crescimento dos países e da área como um todo, per si, foram considerados não-exaustivos pois, mesmo constituindo indicadores válidos na busca de tendências no nível interestadual, limitam qualquer outro avanço no nível intra-estatal se não associados a outros indicadores de desigualdade.

Entre estes, um dos mais conhecidos, o índice de Gini, associado à Curva de Lorenz, quantifica a distribuição de renda em termos de percentual de indivíduos que se posicionam nos diversos degraus de rendas, formando, assim, uma curva progressiva do mais pobre ao mais rico (a análise é feita por escalões e é calculada uma média para cada e uma progressão diversamente linear entre eles). Quanto mais a curva de Lorenz estiver "esticada", isto é, tiver seu menor comprimento, mais igual é o índice. Ao contrário, quanto mais "frouxa" e comprida, em aderência aos eixos, estiver, mais desigual resultará o índice.

\section{Gráfico 2a: A Curva de Lorenz}

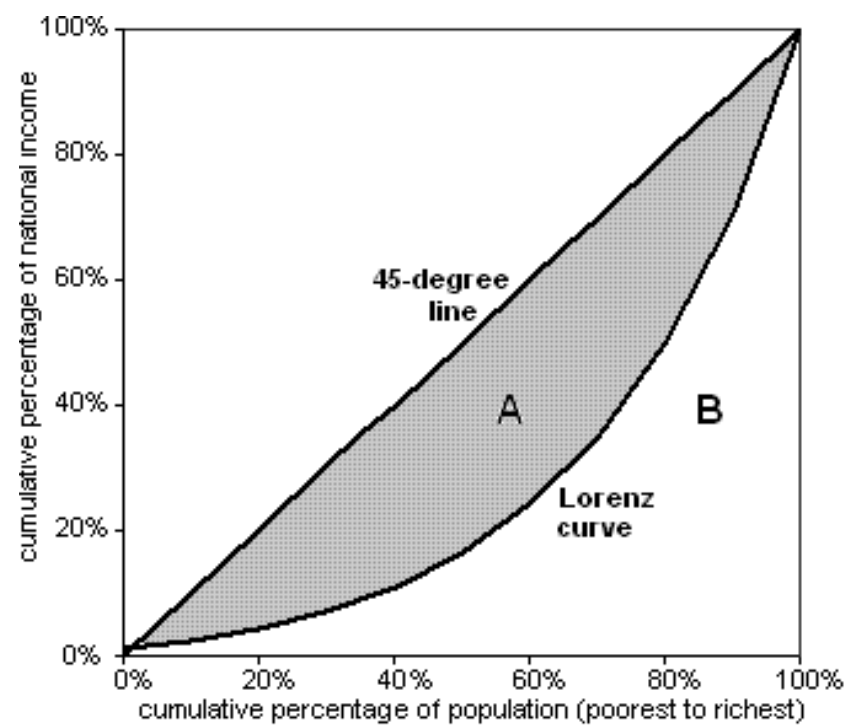

Fonte: Sen, A. ${ }^{28}$.

\footnotetext{
${ }^{28}$ Sen, A. On Economic Inequality. 1973: 30
} 
São representadas as fatias da população da mais pobre à mais rica e a porcentagem de salários, do mais baixo ao mais alto. O Índice de Gini calcula-se dividindo a área inclusa entre a diagonal e a curva de Lorenz (A) pelo triângulo direito $(\mathrm{A}+\mathrm{B})$.

Existem alguns problemas relacionados a esse tipo de medição. Apesar do índice de Gini fazer fotografias da distribuição de renda em uma determinada população, este não tem a pretensão de mostrar qual é a composição real da distribuição, nem sequer ver que tipo de evolução a distribuição apresentou ao longo de um período. Para entender melhor porque não podemos utilizar exclusivamente Gini aos fins dessa pesquisa, temos que dar uma olhada mais de perto na curva de Lorenz e entender bem o que ela significa.

$\mathrm{Na}$ verdade, sem ter específicos conhecimentos no campo estatístico ou econométrico, podemos facilmente entender que, a partir do zero e até onde se vê a "acentuação" mais marcada da curva, temos a faixa de população com a renda mais baixa. A partir de quando a curva de Lorenz muda sua inclinação para o alto, teremos a fatia de população com os salários (ou as rendas ou as riquezas, dependendo das variáveis) mais elevados ou crescentes.

Tendo em mente esse tipo de comportamento da curva (e deste índice), não podemos observar qual é a distância entre os diversos degraus, pois essa informação se perde no momento em que cada ponto do eixo $x$, que representa uma parte da população com rendas crescentes, na verdade mostra o valor das rendas acumuladas entre o zero e o próprio ponto. Não temos nenhuma informação indicativa do que o ponto especificamente represente e qual é a quantidade de pessoas que fazem parte daquele grupo. É uma mera média que serve para fins estatísticos de auxílios a outros estudos. Na verdade, sua inclinação nos dá o valor da renda do ponto em análise, mas nunca saberemos "quem é” o ponto. 
Gráfico 2b: Parcelas de rendas nas quatro fatias acumuladas de $25 \%$ da população.

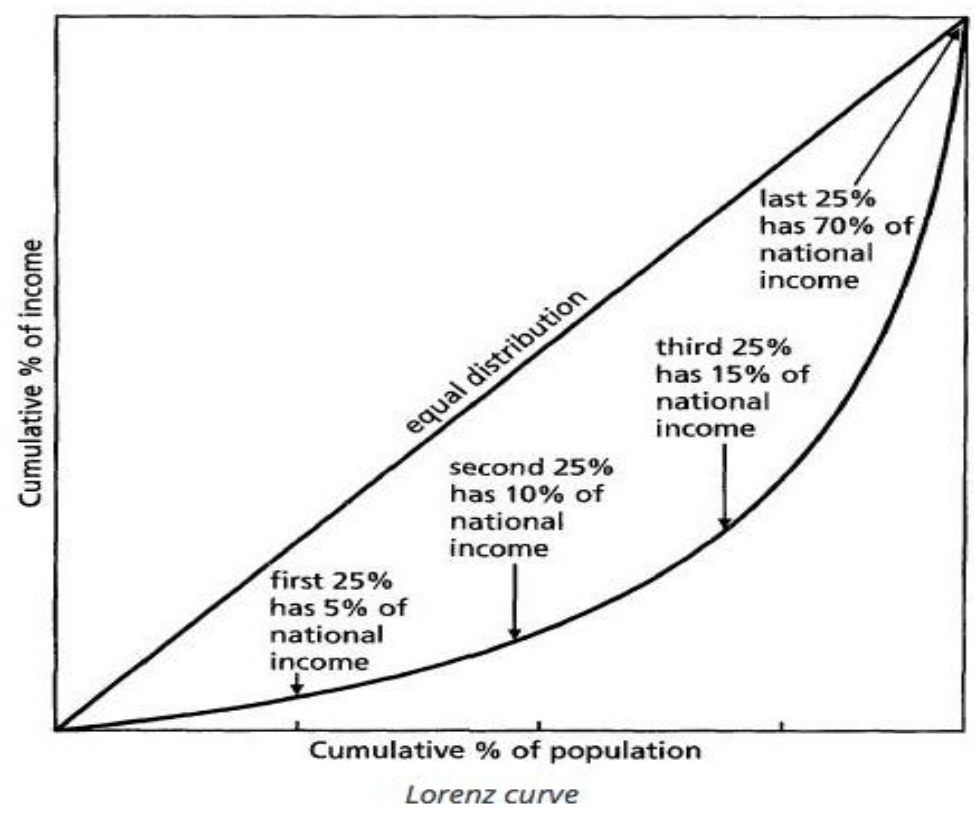

Fonte: Sen, A. $(1973)^{29}$

Além disso, o índice de Gini é sensível à quantidade de indivíduos entre dois níveis de renda e não ao tamanho daquelas rendas. Tanto é que a diferença entre quem ganha US\$ 2000 e US\$ 1900 é a mesma que intercorre entre o indivíduo que ganha US\$ 200 e US\$ 100. Não é difícil entender que isso nos apresenta problemas tanto ontológicos quanto analíticos muito grandes, quando não associamos outro tipo de estudo a esse.

A ampla aceitação do índice de Gini, de qualquer forma, foi um turning point no estudo das desigualdades pois, seu uso contínuo fez com que se mostrassem algumas tendências distributivas. Todavia, é preciso, mesmo que ostensivamente, frisar o quão parcial pode ser considerado o estudo desse coeficiente e o quão importante é conduzir uma análise mais abrangente para que se tenha uma visão mais materialista e real do objeto de estudo.

No caso da presente pesquisa, conforme abordado na "Parte I" introdutiva, é imprescindível entender que tipo de relação existe entre as diferentes partes da população, entre estas e o mercado e como o Estado se posicionou em relação aos diversos períodos que acompanharam as diversas distribuições.

${ }^{29}$ idem 


\begin{abstract}
Abarcar-se-á uma análise por país da área a fim de estudar as tendências destes depois da liberalização dos mercados ou em outras mudanças de regime econômico. Um dos primeiros aspectos que chamou a atenção foi que existem tendências regionais no índice de Gini, mesmo que com algumas exceções. As regiões que mais se destacaram no aumento da desigualdade foram as do leste europeu e as do norte e se verá por quais motivos. Porém, precisou-se entrar no estudo da polarização para o fim já explicado de acompanhamento da estratificação em um determinado país e se verá que, mesmo nessa medição, pode se observar uma tendência por área.
\end{abstract}




\section{2. $O$ conceito de polarização}

Uma análise que avalie o quanto o crescimento econômico afetou a igualdade na Europa, precisa ser dinâmica, isto é, levar em consideração quanto, e se, a mobilidade social mudou, redefinindo, ou não, a ordem intra-estatal. Para fazer isso, o índice de Gini precisa ser complementado com outras técnicas pois ele não considera a estrutura social de um país. Um índice que pode auxiliar na análise é o de polarização. Este último considera quanto as pessoas de uma mesma classe se aproximam ou se afastam entre elas, gerando aglutinações (polos) entre indivíduos e um espaçamento maior (gap) entre as classes, no primeiro caso, e diluindo os polos preenchendo o gap entre eles, no segundo. No primeiro caso, com a aglutinação de pessoas da mesma classe (intragrupo), se forma um gap intergrupos; no segundo caso, o de afastamento, existe uma distribuição social mais homogênea.

Gráfico 3: Concentração das rendas de uma população com dupla polarização.

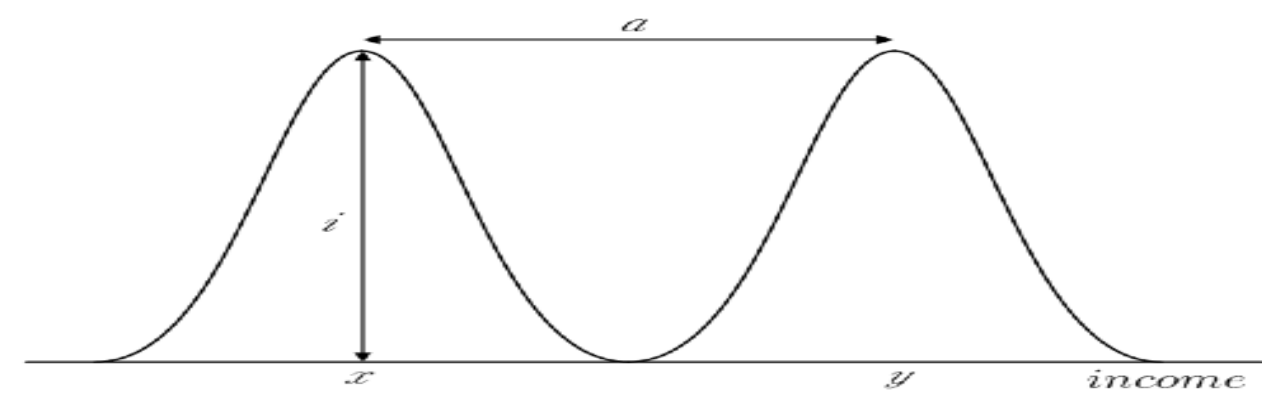

Fonte: Oliver, X., Piccoli, L., Spadaro, A. Redistribution and Polarization Impact of the European Redistribution Architecture: an Analysis Using Microsimulation Techniques, 2008, p. 15.

Estudos do tipo já foram conduzidos (Esteban e Ray, 2011, Clementi e Schettino, 2013, entre outros) para mostrar quanto um país é cristalizado em sua estrutura social, isto é, quanto ele não apresenta mobilidade social. Já se viu que países que apresentaram um melhoramento do Gini às vezes tiveram um alto índice de polarização e vice-versa. Isso não é surpreendente, pois, quando se pensa na distribuição social, se um indivíduo perde, mas outro ganha, na mesma proporção, o índice de Gini não muda. Por outro lado, isso será revelado no índice de 
polarização pois as perdas e os ganhos mudaram de "posição" e podem gerar picos de polarização e consequentes gaps entre as classes.

Esteban e Ray (2012) conduziram os estudos mais profícuos no assunto tratado. Segundo eles, todos os índices que medem a polarização têm as seguintes peculiaridades:

a) the impact of single individuals on polarization measures is negligible, since polarization describes the features and relative positions of social groups

b) with two or more groups, polarization increases when intragroup inequality is reduced

c) polarization rises when distances between groups are increased

The conceptual difference between 'polarization' and 'inequality' is most evident when considering property $b$ ), which is violated by all standard inequality measures. ${ }^{30}$

Nos países que nos últimos anos vivenciaram um crescimento muito forte e um aquecimento da economia (entre eles está o Brasil) a mobilidade social é muito alta. As posições da concentração de renda mudam com alta frequência e hoje existe um gap que indica a falta de uma classe "média" (apesar do índice de Gini não mostrar isso e diversos economistas apontarem para um novo papel da classe média).

Frequentemente, a polarização é associada ao fenômeno do desaparecimento da classe média. Na década de 1980, tanto na Inglaterra quanto nos Estados Unidos, houve uma fortíssima polarização e a formação de um gap que indicou esse vácuo correspondente à classe média (Wolfson 1994; Jenkins, 1995).

$\mathrm{Na}$ Europa, aconteceu de forma mais exacerbada. O índice de polarização apresenta só algumas concentrações, porém a estrutura, assim constituída, não se desloca para o centro. Isso significa que não existe mobilidade social positiva isto é, que desmantela os polos - ou que ela é muito baixa.

Com o fenômeno da polarização das faixas sociais, há de se esperar, conforme aconteceu já, a manifestação de uma insatisfação forte, motivo de revoltas e mudanças. Segundo Duclos et al. (2004), isso pode ser dado por dois efeitos que

\footnotetext{
${ }^{30}$ Esteban e Ray (2012) apud Brzeziński (2013: 6)
} 
são os dois lados da mesma moeda: de um lado, a alienação percebida pelos indivíduos de um mesmo grupo; do lado avesso, a identificação que os indivíduos do mesmo grupo sentem um em relação um ao outro e cada um deles com o conjunto. Essa abordagem considera que a polarização requer que os indivíduos se identifiquem um com o outro do mesmo grupo socioeconômico e que sintam alienação em relação aos demais grupos.

Um outro ponto importante que, agora, podemos levantar para a reflexão é quanto e como o crescimento de um país e essa desigualdade são relacionados. Assim, existem de um lado estudos que mostram como o aumento da desigualdade influenciou negativamente o crescimento do PIB dos países em análise ${ }^{31}$, ao mesmo tempo em que outros trabalhos conduzidos mostram como ao crescer o nível de desigualdade o crescimento do país é acelerado ${ }^{32}$. Os mais salientes, porém, são estudos mais recentes que mostram uma complexidade tanto analítica quanto conceitual dessa relação. Banerjee e Duflo (2003), por exemplo, correlacionam tanto aumentos quanto diminuições do nível de desigualdade a um crescimento baixo da economia de um país. Já Barro (2000) e Li et al. (2009) indicam uma falta de linearidade entre os dois fenômenos. ${ }^{33}$

Mesmo que esses resultados discordem por causa da sensibilidade dos dados e outras variáveis ligadas aos métodos utilizados, de um ponto de vista da Economia Política e da academia de RI estamos propensos, de forma bastante unânime, a acreditar que a polarização geraria efeitos relevantes e interessantes em diversas dimensões. Esteban e Ray, em muitos estudos conduzidos, mostram como os conflitos sociais crescem ao aumentar a polarização. Isso não surpreende pois a estratificação social sempre foi uma prerrogativa de grandes desconfortos dentro da população e isso sempre se manifestou com consequências graves em outros níveis. Os conflitos decorrentes dessa polarização geram, entre outras coisas, impactos econômicos importantes "ao perturbar as atividades de mercado

\footnotetext{
${ }^{31}$ Alesina e Rodrik (1994), Persson e Tabellini (1994), Clarke (1995), Deininger e Squire (1998)

${ }^{32}$ Estes baseiam-se em análises de dados cross-country e outras estimativas. Entre os trabalhos mais reconhecidos, há Li e Zou, (1998) e Forbes (2000).

${ }^{33}$ Brzeziński (2013: 8)
} 
$e$ as relações de trabalho e ao enfraquecer a segurança dos direitos de propriedade". 34

Além disso, outra observação que se faz decorrente do gap que se gera por causa da bi-polarização (o polo das altas rendas juntamente com o polo nas baixas rendas) é a do desaparecimento da classe média. Esse fenômeno, conforme se verá mais adiante, manifestou-se na Grã Bretanha na década de 1980, quando a distribuição mostrou um gap coincidente à parcela média da população formando dois picos extremos nas rendas baixas e altíssimas.

As medições que foram citadas, o índice de desigualdade de Gini e o índice de polarização (ou índice de distância social) nem sempre apresentam um andamento igual. Isto significa que as variações da distância social nem sempre se associam às variações da desigualdade. Pode acontecer que com desigualdade constante tenha um aumento da distância entre rendas. Esse fenômeno pode criar uma forte divergência de padrões de vida em um mesmo território.

Porém, uma combinação dos dois estudos mostra, para os nossos objetivos, as características mais relevantes a serem estudadas e abre uma brecha válida no entendimento da problemática complexa que esta análise pretende introduzir. Uma das variáveis que será analisada, visto que uma das principais preocupações ontológicas tem a ver com a relação entre Estado e mercado e Estado e sociedade, é a adoção da política de transferências, sobretudo no assim chamado regime de welfare, ou a falta desta que se enquadra mais em um contexto de contenção dos gastos e de austeridade fiscal. Veremos como a polarização presente em vários países reflete de forma fiel os comportamentos estatais adotados naquele país.

\footnotetext{
${ }^{34}$ Tradução livre : "by disrupting market activities and labour relations and by reducing the security of property rights" idem p. 9
} 


\section{5.}

\section{As Macro-Regiões}

A partir de 1971, quando os EUA suspenderam a paridade com o ouro, e depois de 1973, quando acabou oficialmente o sistema dos câmbios fixos, os vários países da área tentaram, como já mencionado, um controle internacional de capitais. Foi quando, em 1974, os EUA começaram a eliminar os controles domésticos, que a situação na Europa (e no mundo) mudou radicalmente.

Depois que uma série de manobras reguladoras por parte do governo britânico na primeira metade da década de 1970 faliram em seus objetivos, em 1979 isso "significou o fim da sociedade keynesiana na Grã Bretanha. O tatcherismo estava preste a começar" ${ }^{35}$. A Grã Bretanha, de fato, foi pioneira no continente e os demais tiveram que esperar o Ato Único Europeu de 1986 para começar a seguir regras comuns e chegar, em 1992, a falar em abertura dos mercados. De toda forma, houve logo uma redefinição das políticas internas e dos fluxos tanto comerciais quanto financeiros, estes últimos já tendo como núcleo operativo Londres, depois da criação do Eurodólar da década anterior.

Nos diferentes países, porém, conforme será mostrado, houve processos mais ou menos defasados que levaram a tendências díspares. Na seguinte tabela, se vê como estas podem se agrupar por áreas, em relação ao índice de Gini, e como estas seguem padrões de desigualdade diferentes.

35 Tradução livre: "signified the end of Keynesian society in Britain. Thatcherism was soon to follow" Helleiner (1996: 128) 
Tabela 2: Evolução quinquenal de Gini da Europa por regiões. 1970-2005

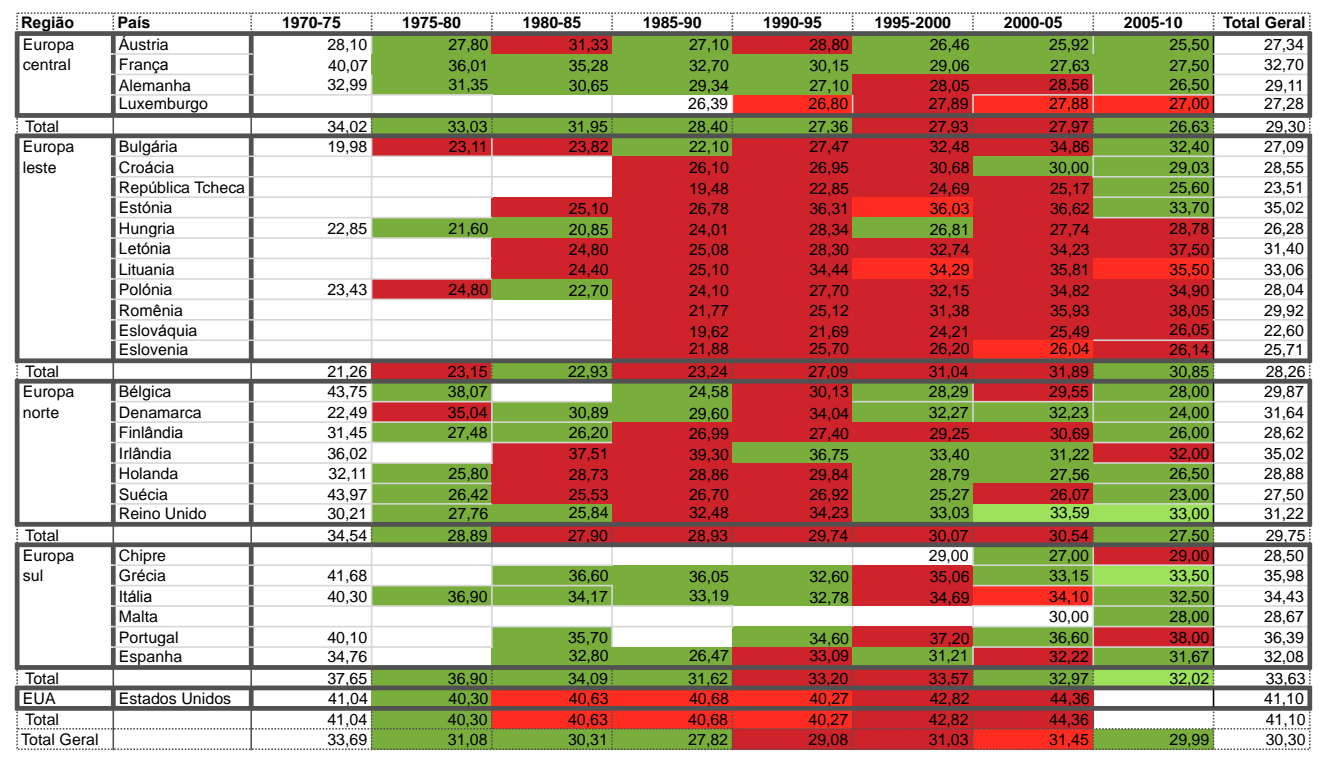

Fonte: Elaboração própria com dados da UNU-WIDER. Em verde escuro, os anos de diminuição do índice; em verde claro, os anos de leve aumento; em vermelho escuro, os anos de aumento do índice; em vermelho claro, os anos de leve diminuição. Todos em relação ao ano anterior. O valor de Gini normalizado a 100. (vide Apêndice na Parte III)

Na tabela 2, ressaltou-se a tendência que o índice de desigualdade de Gini seguiu entre 1970 e 2005, com andamento quinquenal. A primeira coisa a ser dita é que a divisão por áreas se dá principalmente por causa de elementos históricoeconômico comuns, mais que geográficos. Portanto temos o primeiro grupo da EU central com Áustria, França, Alemanha e Luxemburgo, que não tiveram uma forte abertura dos mercados nessas décadas, permanecendo bastante fechados seja para o resto da Europa, seja para o resto do mundo. No entanto, o segundo grupo, o do leste europeu, vivenciou de perto a desagregação do bloco soviético e teve que se deparar com uma realidade muito mais insustentável que a do resto da Europa. A UE setentrional, no terceiro grupo, conta com as economias, assim chamadas, de Welfare e, já nessas décadas da análise, proclamavam-se como tais. No grupo EU do sul estão aquelas economias no estilo "mediterrâneo", ou seja 
pouco diversificadas e com escasso crescimento (de forma geral). Por fim, quis se comparar essas regiões com os EUA da época, baluarte do liberalismo e defensor (juntamente com a Grã Bretanha) da abertura dos mercados.

Na tabela, foi feita uma média por quinquênio assim como uma média entre zonas rurais e zonas urbanas, pois, sobretudo por essa última aproximação, foram divulgados índices de Gini das zonas urbanas para alguns anos e índices de zonas rurais para outros, não sendo possível a escolha de um só ou uma comparação ano por ano entre estes. A média calculada, de qualquer maneira, fornece um bom indicador das tendências regionais para fins comparativos.

A análise do índice de polarização, abordada no capítulo 4, será desenvolvida no contexto de certos países no próximo capítulo, e essas tendências serão estudadas à luz dos contextos nacionais, depois de fazer um apanhado das relações Estadomercado e contexto nacional-contexto internacional para poder, finalmente, entender o que aconteceu na estrutura socioeconômica dos países analisados e como essas estruturas podem ser comparadas entre os países da mesma área. 


\subsection{Europa Central}

No primeiro grupo, a tendência que facilmente se destaca mais ou menos por todos os países é de diminuição do Gini. Na Áustria, a partir de 1980 houve uma melhoria na distribuição de renda. Porém, essa diminuição começou a frear para permanecer estável logo na entrada do país no mercado único, em 1995. De qualquer forma, com um valor médio de 27,34, a Áustria é um dos países com o Gini menor da União ${ }^{36}$.

A França, cuja economia não sofreu repentinas aberturas e cujo Estado sempre teve um papel determinante na distribuição de renda, despesa pública e outras políticas de caráter social, registrou um índice de Gini decrescente a partir da década de 1970 que foi caindo mais rapidamente sobretudo entre os anos 1980 e 1990. Desde 1981, ano da eleição do presidente Mitterrand, a França passou do dirigisme da própria economia para a era do rigueur na qual o país cresceu com uma economia planejada. De fato, mesmo que a França seja considerada um país altamente liberalizado, sempre teve uma forte presença do Estado nas decisões inerentes, por exemplo, às condições de trabalho e aos salários, aos setores bancário, da energia e outros.

Para a Alemanha, falar em um índice "unificado" é historicamente bastante efêmero, pois, pelo menos até sua unificação oficial de 1989-90, houve uma diminuição, mesmo que leve, que logo após a queda do Muro de Berlim apresentou uma contra-tendência. Isso é devido ao fato de que o Gini pré-queda do Muro foi calculado por várias fontes para as duas Alemanhas separadamente e, depois disso, foi feita uma média. Decorre disso que por alguns anos, nem na Alemanha Ocidental, nem na Alemanha Oriental houve aumento de Gini pois não tinha uma comparação entre uma e outra região (que, de fato, resultavam bastante desiguais). Depois da unificação, o índice de Gini aumenta de forma quase "falsificada", visto que se compara à média das duas Alemanhas dos anos precedentes, e não ao Gini destas juntas como um único país.

Mesmo que a tendência de Luxemburgo seja de subida, não há como fazer nenhuma comparação pois faltam muitos dados dos anos antecedentes.

\footnotetext{
${ }^{36}$ Lembrando que quanto menor o valor do índice, menos desigual é a população.
} 


\subsection{Europa do Leste}

Como foi citado, os países do leste europeu tiveram uma história diferente pela proximidade com o bloco soviético. Todos os colocados no grupo tiveram fortíssimas ligações comerciais com o bloco (alguns faziam parte deste) e registraram perdas muito altas ao se desfazer do mercado baseado no rublo (COMECON) em 1991.

Com efeito, esses países faziam parte de um regime de "economia planejada" que visava prover as necessidades básicas a todos de igual forma, como o sistema de instrução, o sistema de saúde pública, salários unificados, entre outros, mantendo todos os indicadores econômicos e sociais sob o controle do estado.

Com a passagem para o regime de mercado, na época de ouro do neoliberalismo, todos os indicadores começaram a acompanhar a evolução do equilíbrio entre demanda e oferta de bens e serviços. Os serviços de base também entraram na definição desse regime econômico. Apesar da confiança que se tinha nesse tipo de sistema, os indicadores sociais despencaram rapidamente e seguiram com níveis baixos e estão em diminuição até os dias de hoje, sobretudo para alguns países.

Gráfico 4: Índice de Gini pré e pós transição do regime econômico nos países exsoviéticos

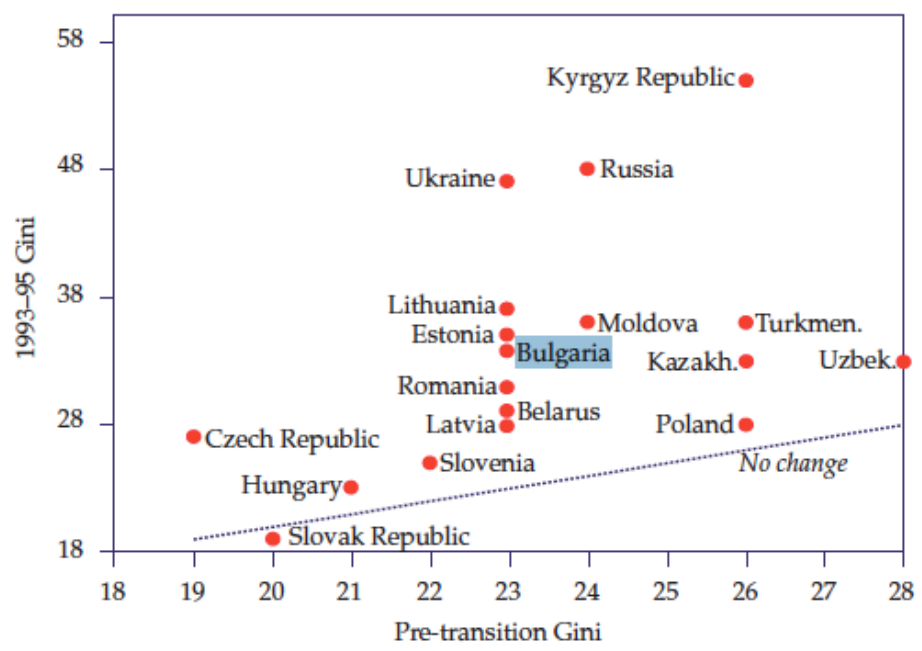

Fonte: Milanovic, B. Income, Inequality, and Poverty during the Transition from Planned to Market Economy, 1998, p. 42. 
Durante quase duas décadas, a maioria destes países passaram por uma forte inflação e uma queda relevante nas exportações. Praticamente, sobretudo os países que faziam parte da URSS, Lituânia, Letônia e Estônia, mas também os que faziam parte da área COMECON (exemplo dos mais pertinentes é a Bulgária que teve um aumento muito amplo e rápido da desigualdade) apresentam um aumento no índice de Gini. Isso pode atribuir-se à passagem de um sistema de propriedade social dos meios de produção a um sistema liberalizado depois que começaram a ser implementadas as condições para entrar na economia de mercado. Por exemplo, na Polônia, com o primeiro governo não-comunista de 1989, o ministro da fazenda Belcerowicz começou a famosa "terapia de choque" visando controlar a hiperinflação, o que, em um primeiro momento, deu origem a um aumento repentino da desocupação e da desvalorização da moeda. Na Hungria, 800 mil trabalhadores perderam os empregos em 1993 por causa do fechamento maciço das fábricas ${ }^{37}$. A "solução" para a criação de novos trabalhos achou-se na entrada de capital multinacional e

"The state companies that were privatised in Hungary were sold at rather low prices; however, they went with the obligation of modernisation and additional investments. The state also gave tax reductions for all those who reinvested their domestic profit in the country. Similarly, infrastructural investments by the state were all kept at a relatively high level. It was important to keep the cost of the labour force low, remembering that while factories in Hungary are doing lowlevel work, Magyars are competing with the labour force in China, Poland, Mexico, and the like." 38

Com os salários baixos e o aumento da produtividade, a Hungria (entre outros) conseguiu fomentar o crescimento nacional em detrimento, porém, do bem-estar e da redistribuição social:

"Transition also meant the creation of a smaller state. This was mostly realised by privatisation, but it also meant the reduction of social expenditures and pensions. Consequently, poverty increased enormously throughout the whole period. Social differences increased significantly, and the social net almost completely fell apart. But, while people lived at a lower level than during communism, the external investments were the highest in the region. “39

\footnotetext{
${ }^{37}$ Endre (2004: 86)

38 idem (2004: 87)

${ }^{39}$ idem (2004: 88)
} 
A Estônia, que tem uma média de Gini do período de 35,02, a mais alta dos países europeus considerados, começou seu crescimento econômico a partir de 1995 quando sua inflação diminui e, a partir de 1998, a maioria dos segmentos de sua economia são privatizados. É exatamente depois da liberalização dos mercados que se registra o ápice dos valores de Gini em 36,62, o mais alto de qualquer quinquênio de todos os países considerados. 


\subsection{Europa do Norte}

O grupo setentrional, mesmo contando com as menores desigualdades em uma análise histórica ampla, apresentou em alguns casos uma estabilidade do Gini e em outros um considerável aumento. No caso da Finlândia, por exemplo, hoje conhecida como um dos países com a menor desigualdade do mundo, se vê que entre 1985 e 2000 o índice de Gini pulou de 26,20 para 30,69. Em meados de 1980, justamente quando cresceu a desigualdade, a Finlândia ainda comercializava com a União Soviética quando começou com suas privatizações. A abertura dos mercados e a entrada da concorrência geraram uma forte queda $\mathrm{e}$ endividamento do setor bancário. Juntamente a esse endividamento, aumentou a desocupação que chegou, em 1993, a 500 mil desempregados no país.

Na Grã Bretanha, com a entrada da primeira ministra Thatcher em 1979 e o início das privatizações, a desocupação alcançou os 3 milhões de desempregados, levando o país a um tumulto que durou alguns anos e deixando o governo Thatcher com a fama mais controversa da história econômica da Europa. De toda forma, foi justamente nesse período que o país registrou um aumento substancial da desigualdade, cujos valores passaram de 25,84 para 34,23, ou seja, aumentou de 8,39 pontos percentuais e chegou a ser um dos maiores aumentos dos quinquênios considerados da União.

Nos demais casos, uma estabilidade caracteriza Holanda e Suécia, as quais sempre tiveram uma economia fortemente guiada pelos respectivos estados e que, mesmo passando por algumas privatizações, não deixaram de ter um papel ativo nesses países. A Irlanda é um ponto fora da curva por ter tido uma diminuição progressiva da desigualdade. Esta passou por reformas significativas a partir da década de 1980. Essas reformas visavam ter uma "Parceria Social" que seria uma série de pactos neo-corporativistas entre governo, trabalhadores e as uniões de comércio. Por esse motivo, a Irlanda vivenciou no período 1995-2000 um melhoramento econômico que a deixou conhecida como "tigre celta" ${ }^{40}$.

\footnotetext{
${ }^{40}$ Smith, C. 'Ireland', em Wankel, C. (ed.) Encyclopedia of Business in Today's World, California, USA, 2009.
} 


\subsection{Europa do Sul}

$\mathrm{Na}$ Europa meridional houve uma tendência de diminuição de Gini nos anos "dourados" de crescimento dos países que, porém, apresentou uma conta muito salgada na hora em que a crise que afetou o continente chegou, no início de 1990, e se arrastou por uma década. Em especial, Itália, Grécia e Portugal foram as economias mais afetadas por esse processo. Os índices dos dois países registraram altas nos anos posteriores à implementação de políticas fiscais pouco sustentáveis.

Esses países apresentam uma estrutura econômica de tipo "mediterrâneo": a taxa de desemprego sofreu um aumento progressivo depois da crise da década de 1990 e, novamente, depois da de 2008, resultado de um sistema precário em todos os ramos produtivos e da predileção à implementação de medidas de austeridade para enfrentar os efeitos dessas crises. O resultado dessas medidas foi, portanto, absorvido primeiramente pelos trabalhadores em senso estrito mas, também, pelo lado de todas as despesas públicas e, portanto, da saúde, dos transportes e, em última instância, da qualidade de vida através de uma taxação indireta mais incidente.

Os movimentos dos trabalhadores - e da sociedade civil como um todo - foram aumentando de forma mais incidente depois que os efeitos econômicos das decisões políticas tomadas começaram a exacerbar as relações inter-classes ${ }^{41}$.

\footnotetext{
${ }^{41}$ Famoso, nos anos posteriores à crise de 2008, foi o slogan adotado por manifestações em diversos países da região que exortava "España, Italia, Grecia y Portugal, hace hace falta, la huelga general!".
} 


\subsection{Um olhar sobre os EUA}

A fim de melhor entender as tendências que as várias regiões tiveram, um outro importante ator do contexto internacional que precisa ser considerado são os EUA, que, com efeito, deram o primeiro passo para que uma nova ordem viesse a se delinear no cenário mundial. A economia norte-americana, assim, como já citado, se desatou das obrigações com o resto do mundo ao decretar o fim da paridade com o ouro e o início da moeda flexível.

Da mesma forma, a economia do país teve que encarar as crises petrolíferas até 1992, quando começou seu crescimento que, pode-se dizer, permaneceu constante até a crise de 2008. Curiosamente, o índice de Gini dos EUA parece permanecer estável durante todo período das crises do petróleo, começando a aumentar perigosamente logo no início de 1990 em diante. O que é interessante ver é que os EUA mantiveram seu status de superpotência durante todos esses anos e que, evidentemente, apresentaram o índice de Gini mais alto comparado com todos os outros países da Europa, chegando a registrar em 2000 um quase inacreditável valor de 44,36, valor que naquele mesmo ano era quase igual ao da Costa Rica $(45,8)$ e 47,7 em 2011.

O nível de desigualdade e de polarização das rendas nos EUA é um dos mais elevados entre os países industrializados e cresceu, também, sistematicamente. Entre 2009 e 2010, 93\% das rendas colocou-se no 1\% mais elevado da distribuição das rendas ${ }^{42}$. Os dados coletados pelo Census Bureau através do Current Population Survey, relatam que, em 2012, o quintil mais pobre das famílias recebeu somente $3,4 \%$ da renda do mercado equivalente, enquanto o quintil mais rico recebeu $49,9 \%$.

Um nível de desigualdade tão elevado, manifestando-se em menores oportunidades para as próximas gerações, é um fator destoante com o tipo de policy, mas, também, com o tipo de cultura, que os EUA promovem. Sobretudo

\footnotetext{
${ }^{42}$ Stiglitz (2010)
} 
em termos de serviços básicos para a sobrevivência, o país tem muitas lacunas no sistema de educação e de saúde pública.

Além disso, mobilidade social, que é já inferior às de muitos países europeus, continua em níveis muito baixos. A redistribuição - como será mostrado também para outros países da Europa - negligencia resoluções de problemáticas mais complexas pois, embora a política das transferências sociais beneficie os mais pobres, esta não reduz o nível de desigualdade. A variável impeditiva não concerne à quantidade de recursos transferidos mas a estrutura do sistema ${ }^{43}$. $\mathrm{O}$ centro LIS mostra que, em 2013, o valor do índice de Gini da distribuição das rendas do mercado era inferior ao de muitos países da Europa como Alemanha ou Grã Bretanha. Porém, a redistribuição não gerava uma melhora na percentual de queda do índice além de $0,15 \%$, enquanto na Alemanha, por exemplo, conseguia chegar em $0,24 \%$ de diminuição.

A elevada desigualdade nos EUA tem sobretudo causas estruturais, como a diferença nos níveis de instrução e de competências profissionais, resultado da atuação do livre mercado em uma economia capitalista avançada. Este é um dos motivos pelos quais uma ação redistributiva não seria suficiente para reduzir o nível de desigualdade.

Comparar a economia e as políticas europeias com a dos EUA nos auxilia a entender não somente como as diferenças históricas contaram nas tomadas de decisão dos diversos Estados quanto, também, de que forma a escala do mercado, e o relacionamento que o Estado tem com este último, é importante e precisa entrar em análises que pretendem entender o fenômeno da desigualdade.

\footnotetext{
${ }^{43}$ Gornick, J. Inequality, it metters. LIS Center, 2013.
} 


\section{6. Os países e seus históricos}

\subsection{França e Alemanha}

\section{França}

Conforme Piketty (2007) analisa em seu estudo, a França teve uma diminuição dos índices de desigualdade durante a primeira metade do século XX. Isso teria acontecido sobretudo acidentalmente ${ }^{44}$.

Como afirmar isso? Precisa-se olhar sobretudo para as políticas de impostos que são os principais impulsos para alguma mudança na estrutura do país. No início do século, os impostos sobre a renda foram introduzidos no país e, desde o início, o registro desse imposto mostrava somente a parte que gravou sobre quem possuía bens imóveis de valor suficiente para entrar na categoria mais alta da distribuição social. Isso passou de 5\% em 1915 a $60 \%$ na década de 1970. Mas o que mais desperta interesse em relação ao sistema de impostos na França é um dos itens chamado "imposto salarial", introduzido em 1917, que incidia progressivamente sobre a quantia salarial do trabalhador. Isso não só significou uma mudança econômica, como, sobretudo, uma mudança social, do momento que todos os empregadores tinham a obrigação por lei de declarar quanto cada seu trabalhador recebia mensalmente ${ }^{45}$.

A medição e o registro dos impostos também ganharam, assim, confiabilidade e puderam ser avaliados estatisticamente. Piketty (2007) usa uma metodologia de concentração paretiana por faixas percentuais e realiza um estudo olhando para a parte mais alta da população para ver quanto esta perdeu ou ganhou em termos distributivos ao longo do século XX. Como visto, isso pode resultar insuficiente para uma análise mais aprofundada, porém se propõe uma primeira reflexão confiável sobre algum fenômeno sócio-econômico, pois, se fundamentarmos a pesquisa na análise da evolução do capital nos diversos países da Europa, o fenômeno que sempre veremos é uma repentina oscilação no comportamento dos

\footnotetext{
${ }^{44}$ Piketty (2007: 43)
}

${ }^{45}$ idem, p. 46 
investimentos, nas transferências e remessas e nas manobras do governo para garantir o crescimento. Uma mudança mais sistêmicas, envolvendo todas as demais faixas da população, é mais demorada e mais difícil de se analisar; porém, imprescindível para futuras reflexões.

De toda forma, se considerarmos a análise de Piketty (2007) para a França, podemos ver que o período mais significativo foi entre as duas guerras.

Gráfico 5: Concentração de renda do decil mais rico da população, França 190098

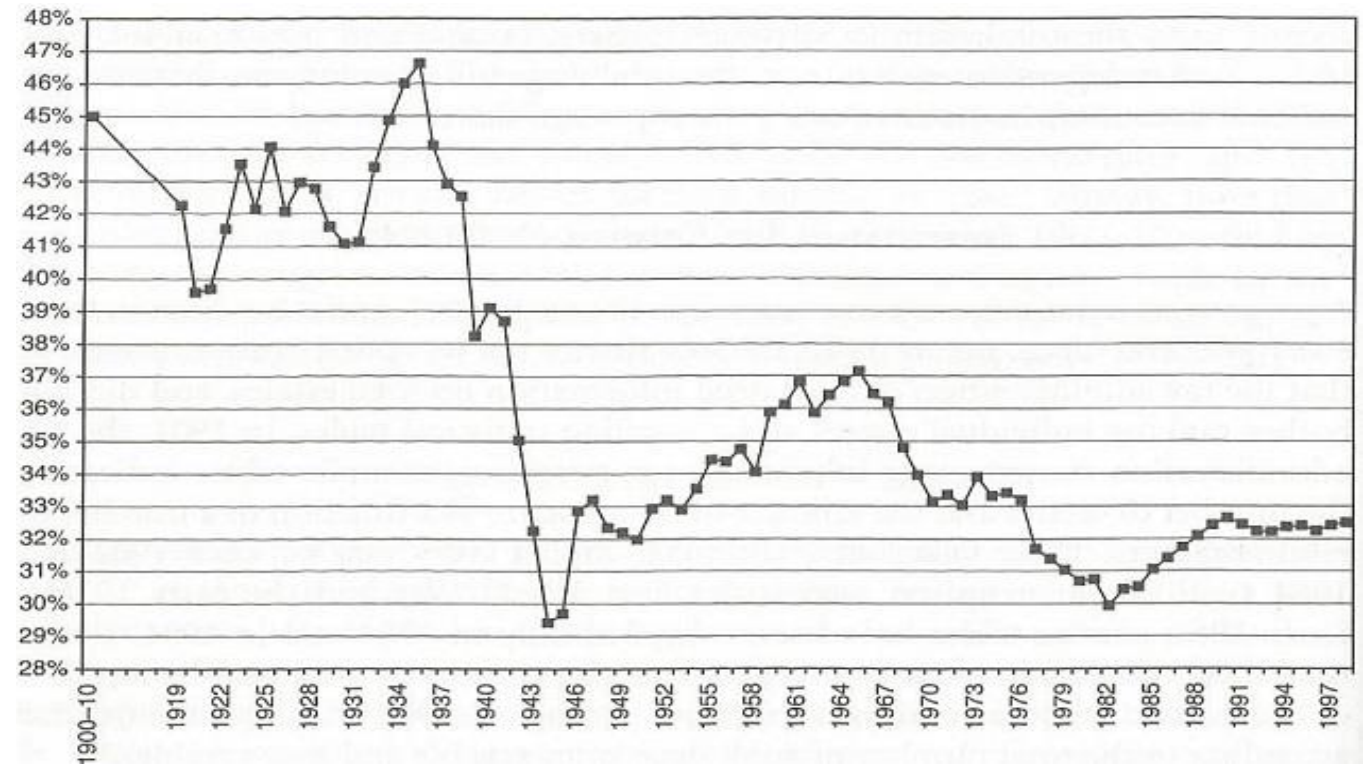

Fonte: Piketty, 2007, p. 48.

O período do início da década de 1930 foi marcado pela Grande Depressão que abalou, entre outras, a economia francesa. Podemos ver com essa pertinência o aumento da desigualdade naquela década. Com o objetivo de preservar o próprio status quo, a economia careceu de investimentos. De alguma forma, poderia se refletir se essa diminuição não piora também o status das faixas mais baixas, pois os governos, sensibilizados pela perda de atividade financeira dos ricos, revertem a ordem taxando "menos" progressivamente, gerando mais desigualdade, somente que, dessa vez, no sistema como um todo. Porém, Piketty (2007) explica: 
"It is also important to emphasize that the decline of top incomes is the consequence of a decreased concentration of capital income and not of a decline in the share of capital income in the economy as a whole $e^{\prime 46}$

A renda do capital (dividendos, juros, etc.), como mostra o autor, não diminuiu ao longo dessas décadas, o que mudou foi a concentração dessa renda. Mas a ferramenta dos impostos, que de fato aumentaram entre as duas guerras, estava começando a gerar na França o efeito contrário: ao aumentar os impostos, a evasão fiscal aumentava percentualmente. Isso não só não diminuiria a desigualdade, quanto a teria aumentado pois quem continuava pagando os impostos eram as faixas mais baixas, sendo nessa faixa proporcionalmente mais viáveis as contribuições.

Depois da reconstrução da Segunda Guerra, vemos no gráfico que a desigualdade dessa faixa se estabiliza. O que aconteceu com a população como um todo? Sobretudo a partir da década de 1970, esta começou a experimentar uma diminuição da desigualdade. A interpretação dessa mudança, porém, precisa ser mais detalhada. A interpretação de Piketty (2007) tem como tese central o fato de que a concentração de capital diminuiu e, dessa forma, diminuiu também a desigualdade. O autor, em seu estudo empírico, observou que, considerando 1910 e 1990, no segundo período a distribuição de imóveis era quatro vezes menor que em $1910 .{ }^{47}$

No período entre as duas guerras, aquele sistema progressivo de impostos sobre o capital e sobre a herança teve um leve impacto sobre a faixa mais alta de renda na França. No entanto, não podemos subestimar a intensidade que esse impacto gerou na acumulação de capital e na herança nos anos a seguir, conforme já foi citado. Uma das conclusões poderia ser que os impostos progressivos geraram efeitos de longo e longuíssimo prazo.

A França representa um dos casos em que, ao diminuir a desigualdade em termos de Gini (depois da década de 1970), sua polarização de rendas também diminuiu e

\footnotetext{
46 idem, p. 57
}

${ }^{47}$ idem, p. 59 
os polos extremos que existiam antes dessas redistribuições se mobilizaram para o meio criando uma certa uniformidade:

Gráfico 6: Distribuição relativa de rendas na França, 1979-1994

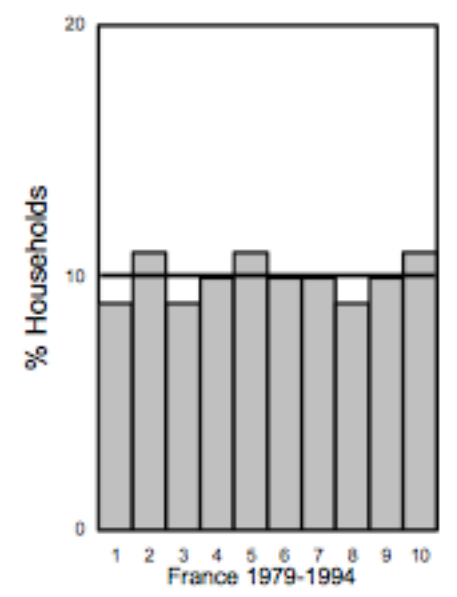

Fonte: Alderson, A. S., Beckfield, J., Nielsen, F. Exactly how has income inequality changed? Patterns of distributional change in core societies, LIS Working Paper Series, No. 422, 2005, p. 26

O esvaziamento dos níveis mais altos, devido, segundo Piketty (1998), à diminuição da concentração de capital nos degraus daquelas faixas de alta renda, fez com que se verificasse a homogeneização indicada. 


\begin{abstract}
Alemanha
Até a década de 1990, a divisão entre a parte ocidental e a oriental delineava diferenças intrínsecas ao sistema no qual as duas partes viviam. Com a queda do Muro de Berlim e a seguinte abertura entre os dois lados, o trabalho, a vida social, as propriedades e as rendas foram calculados com base nacional, também revelando como oriente e ocidente de um país, que já tinha sido cenário de unificação aduaneira (Zollverein), estavam ligados cada um ao regime de mercado que a bipolaridade mundial tinha imposto durante a Guerra Fria.
\end{abstract}

A Alemanha, hoje, faz parte dos países com os níveis de bem-estar mais altos, mesmo que isso não implique, conforme foi visto até agora, uma distribuição igual. A renda familiar bruta per capita média ponderada da faixa mais alta da população é quatro vezes mais alta em relação a do nível mais baixo. Na análise sobre a distribuição de renda com a metodologia da polarização entre 2000 e 2006 houve uma altíssima polarização de renda, desta forma, tanto a faixa mais alta da população quanto a mais baixa tiveram um aumento muito alto em termos de indivíduos que se enquadram nos dois grupos, gerando assim um gap com poucos indivíduos que pertencem às demais rendas no meio. $\mathrm{O}$ número de pessoas que ganham mais do dobro da média da população cresceu de 6,4\% até 9,2\% nas últimas duas décadas e os indivíduos que ganham menos da metade da renda média passou de $7,3 \%$ a $11,4 \%$. A renda média diminuiu de $61 \%$ para $54 \%$, sinal de uma tendência que pode ser interpretada como uma "contração da classe média" (Esteban e Ray, 2010)

No tocante ao patrimônio, esse gap entre o "polo alto" e o "polo baixo" é ainda mais marcante. Foi quase exclusivamente a metade superior da população a ter conseguido acumular um patrimônio bruto (isto é, não considerando as dívidas) e, em 2007 , os $10 \%$ mais ricos da população detinham anualmente $61 \%$ do total da riqueza privada. A metade inferior não deteve níveis consideráveis e os $10 \%$ mais pobres são, até hoje, endividados. Isso levou, entre 2002 e 2007, a um novo afastamento que gera uma ulterior polarização. 
Na Alemanha, onde há por definição oficial uma "economia social de mercado", o Estado tem a obrigação de intervir somente no que concerne à redistribuição para evitar que se crie desigualdade no país. A concorrência, priorizada nesse regime, é incentivada através da abertura dos mercados, das leis que a preservam e da paridade de direitos dos concorrentes. Assim, também existe outro lema do regime que é de ser "responsável” pela inclusão social, operando como redistribuidor através o princípio da subsidiariedade.

A Alemanha, porém, teve um andamento muito destoante entre seu índice de Gini, cujo valor mostrou uma distribuição mais igualitária em sua população, sobretudo no período 1980-1990 (calculando uma média entre Alemanha Ocidental e Alemanha Oriental que passou de 0,30 a 0,27), e seus índices de polarização social, que mostraram valores crescentes até 1995:

Gráfico 7: Índice de Polarização Social (DER 1) da Alemanha por quinquênios. 1970-2005

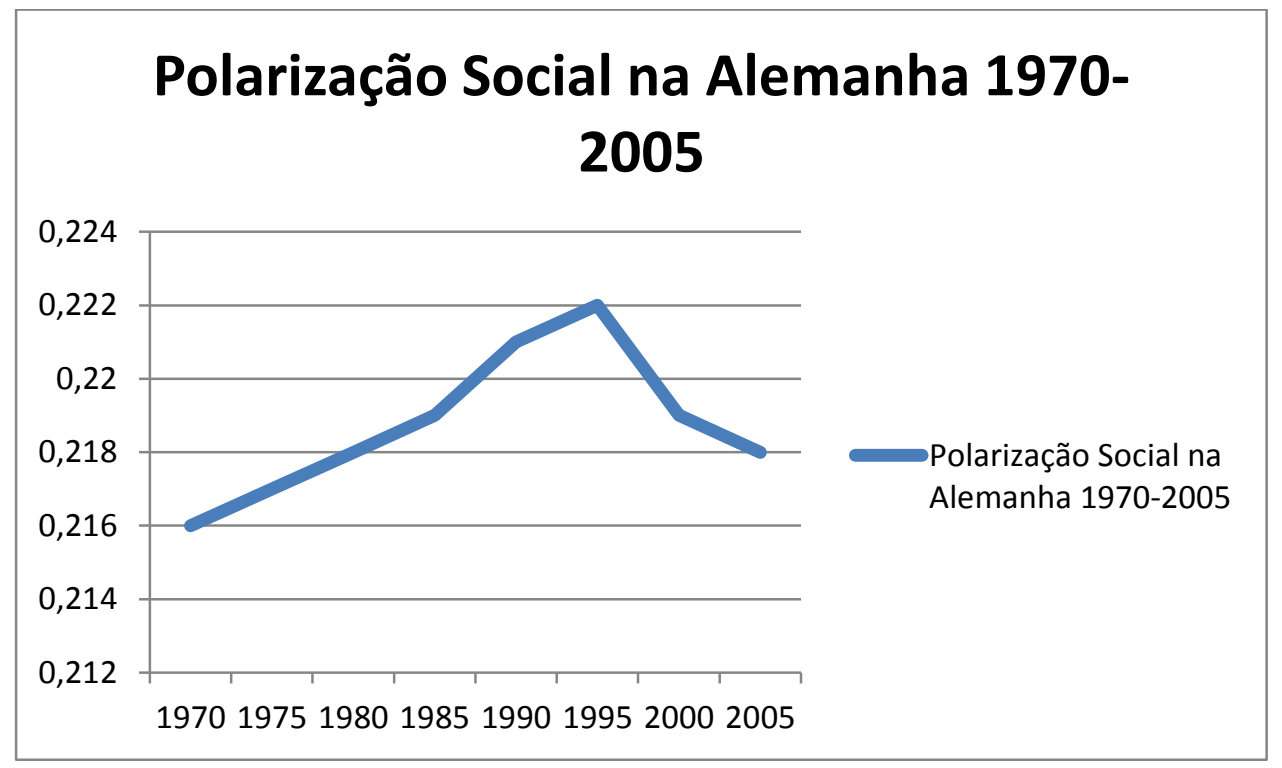

Fonte: Elaboração própria com dados LIS data Center e UNU-WIDER.

A importância desse fenômeno é, mais uma vez, de entender o que análises diferentes implicam. Pelo Gini, nos anos citados, a distribuição da renda se tornou mais homogênea, isso implica um melhoramento para todos que se encontram no meio da distribuição estatística, sem distinção. Segundo o índice de polarização, as rendas se redistribuíram, mas não foram se homogeneizando. Ao contrário, 
vemos que na Alemanha a presença de dois polos distantes se acentua ainda mais no mesmo período.

O Estado alemão de welfare, que se baseia no princípio de redistribuição, aprovou em 2005 o plano "Hartz IV" que é um auxílio desemprego. Paradoxalmente, o fenômeno que podemos observar na curva de Gini é de um aumento da desigualdade desde então, ao mesmo tempo que a polarização social se estabilizou entre 2005 e 2008. Esse plano, na verdade, gerou novas concentrações de renda, porém, no período indicado, em outras faixas da população ao invés de seus extremos. A explicação mais evidente é que o subsídio é vinculado à obrigação de aceitar qualquer trabalho disponível. Na sequência, os beneficiários da bolsa criaram novas classes intermediárias, saindo da estagnação, mas colocando-se em uma posição de dificuldade, ganhando salários abaixo da média em um país com a economia em leve inflação. Esses "novos" trabalhadores contribuíram a esvaziar os polos sociais extremos (saindo da faixa mais baixa e contribuindo à diminuição da renda da faixa mais alta, via redistribuição), porém povoando novas faixas sociais que não são satisfatórias, entre trabalhos precários e fases de desemprego cobertas pelas bolsas.

Uma outra medida que auxilia na análise dessas mudanças na Alemanha é a taxa de risco à pobreza (At-risk-of-poverty rate). A taxa mostra a instabilidade econômica da população. Na Alemanha, em 2009, essa taxa aumentou paralelamente ao índice de polarização social chegando a seu ápice de $15 \%$. Isso revela os problemas de instabilidade nos empregos e dos baixos salários oferecidos.

A mobilidade das rendas - análise dinâmica do índice de polarização apresentou, também, uma estagnação. Esse dado é ainda mais alarmante para a população alemã pois, como é de se esperar, quanto menor for a mobilidade das faixas mais extremas, mais cristalizada é a estrutura socioeconômica de um país. A Alemanha mantém a mesma estrutura de longo prazo desde 2004, com uma proporção de 14/14.5\% da população que se enquadra em uma renda igual ou menor de $60 \%$ do valor do salário médio e outra parte da população, 7.3/7.4\%, que tem renda igual ou maior de $200 \%$ do valor do salário médio. 
Por fim, mesmo que o país não tenha os valores mais adversos da área no tocante à desigualdade, é evidente que o alto risco de pobreza e a baixa mobilidade das rendas não tiveram sinais de melhoramento apesar das políticas pró-ativas do welfare alemão, sobretudo depois do período pós-crise de 2008, por causa da diminuição de empregos. 


\subsection{Grã Bretanha e Irlanda}

\section{Grã Bretanha}

No tocante ao Reino Unido, uma intervenção do governo parecida à da França, a "super-tax" ou "surtax", foi aplicada no início do século XX a fim de incidir sobre as rendas mais elevadas. Sua aparição gerou uma crise política em âmbito parlamentar, encontrando rejeição pela House of Lords. De toda forma, essa taxa, que foi eventualmente implementada, teve também o benefício de coletar dados sobre a renda da população, informação que anteriormente não era muito acurada.

A distribuição de renda na Grã Bretanha caracterizou-se por um aumento do gap inter-classes. Em 1979, Robinson e Kelley publicaram o trabalho "Class as conceived by Marx and Dahrendorf: effects on income inequality and politics in the United States and Great Britain". No artigo, os pesquisadores desenvolvem uma análise sobre o aumento de desigualdade inter-geracional de renda per capita usando uma perspectiva marxista como chave de leitura do fenômeno. Uma análise da mudança na estrutura das classes de uma geração para a seguinte na Grã Bretanha sugere a existência de dois sistemas sobrepostos, porém distintos, de estratificação. O primeiro sistema - os autores explicam - é um sistema de enraizamento de um nível social que tem controle sobre os meios de produção e tem autoridade, o outro é um sistema de status que concerne o status de educação e o status do emprego. Somente comparando o modelo por status com o modelo por classes, pode se ver, por exemplo, uma diferença substancial entre EUA e Grã Bretanha.

Conforme Marx (1867) já afirmava, a Grã Bretanha é o “campo de ação clássico do capitalismo" ${ }^{\prime 4}$. O autor, no Capital (1867), faz uma vasta pesquisa sobre a divisão de classes no país e a situação que cada nível enfrentava no que concerne o trabalho no mercado capitalista. Sua análise mostra, além da distância em renda e qualidade de trabalho que intercorre entre as duas classes principais, o poder de

48 Tradução livre: “classic ground of capitalism” Marx (1867) apud Robinson e Kelley (1979) 
dominação dos capitalistas sobre os proletários baseado na produção de mais-valia que aumentava cada vez mais o ganho dos primeiros em detrimento dos segundos.

Por outro lado, Robinson e Kelley (1979) proporcionam um termo de comparação com os Estados Unidos, cuja divisão da sociedade teria seguido uma divisão por status, mais que por classes. No paper, os autores explicam que, dependendo do caso, uma desigualdade de renda inter-status é mais significativa e relevante se comparada àquela inter-classes. Na visão marxista clássica, de todo modo, a importância do controle sobre os meios de produção indica claramente que a Grã Bretanha é uma sociedade capitalista clássica mais que os próprios EUA ${ }^{49}$.

Uma outra consideração importante a ser feita acerca da estratificação social e sua relativa mobilidade é a "consciência de classe". Esta última nasce de uma identificação de pertencimento a um determinado grupo e evolui conforme o respectivo grupo apresenta exigências cujos avanços só podem ser alcançados coletivamente $^{50}$. Nessa visão,

"education, occupation, and income long have been recognized as important determinants of class identification, and more recent research in both the US and Britain confirms their importance" 51 .

O elemento fundamental que, todavia, temos que priorizar ao fazer uma análise sobre divisão e senso de pertencimento às classes é a hierarquização do trabalho. Na Grã Bretanha, os dados mostram que existe um grande senso de pertencimento à classe de quem detém o poder sobre os meios de produção. Isso é explicado pelo alto ganho na produtividade marginal que empregos mais qualificados tem progressivamente no país. Em outros termos, esse tipo de sistema serve para "fortalecer" uma realidade de estratificação e de crescente desigualdade.

\footnotetext{
${ }^{49}$ Robinson e Kelley (1979:50)

${ }^{50}$ Lucente (2009: 42)

${ }^{51}$ Centers (1949), Hodge e Treiman (1968) e Runciman (1966) apud Robinson e Kelley (1979:52)
} 
Gráfico 8a: Distribuição de renda por decis na Grã Bretanha. 1979-2004

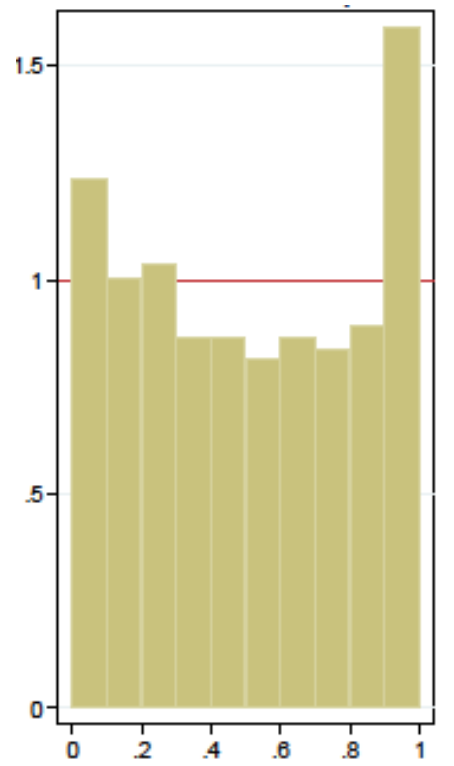

Fonte: Dados Esteban e Ray (2005) e Anderson (2011). Elaboração própria.

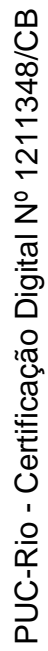

Aparece evidente a aglomeração nos dois polos extremos. Nos países com mais altos PIBs da Europa, a Grã Bretanha apresenta a estrutura socioeconômica mais polarizada de todas, podendo ser comparada à distribuição dos EUA para o mesmo período 1979-2004, confirmando o argumento tratado no parágrafo segundo o qual a Grã Bretanha teria uma estrutura parecida com o país norteamericano pela mesma análise materialista histórica.

Gráfico 8b: Distribuição de renda por decis nos Estados Unidos. 1979-2004

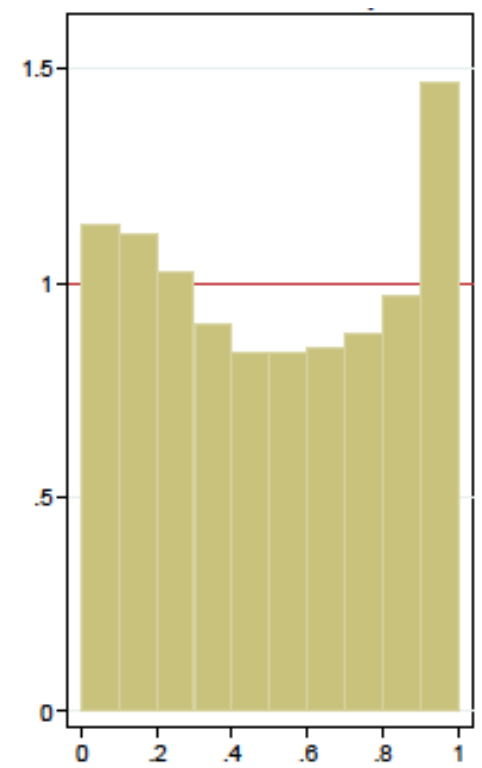

Fonte: Dados Esteban e Ray (2005) e Anderson (2011). Elaboração própria. 


\section{Irlanda}

Apesar dos difíceis ajustes que a economia irlandesa teve que fazer por conta dos padrões da Comunidade Europeia (CE), esta desempenhou bons índices econômicos durante a maioria dos anos da década de 1970. Enquanto a maioria dos países da área não conseguiu evitar os efeitos inflacionários da OPEC durante aquela década, a Irlanda conseguiu manter níveis de crescimento mesmo na onda internacional de recessão.

O aumento rápido dos déficits fiscais começou a puxar o país para novas medidas. O país decidiu que sua moeda não estaria mais atrelada à esterlina inglesa e entrou no European Rate Mechanism (ERM) em 1979, tentando passar da taxa de inflação inglesa à alemã. $\mathrm{O}$ ajuste fiscal e seu enxugamento caracterizaram a década de 1980, porém foi, pelo menos no início, sanado com um aumento dos impostos ao invés de com uma redução das despesas públicas.

A Irlanda ressentiu-se da recessão thatcheriana, embora nem tenha se aproximado aos níveis de crescimento testemunhados pela Grã Bretanha. Nos anos entre 1980 e 1987, houve uma fortíssima recessão, uma repentina queda dos padrões de vida, um drástico aumento do desemprego e uma onda maciça de emigrações para buscar emprego além das fronteiras. A taxa de emprego caiu em 6\% e emprego em artigos manufaturados, em $25 \%$.

O prolongamento desse período de recessão influenciou a balança de pagamentos, cuja tendência tentou-se inverter. Além disso, teve déficits também no setor público. Depois de quinze anos que a Irlanda havia aderido à $\mathrm{CE}$, sua economia resultou abalada e com sérios problemas estruturais. Nesse contexto, a Irlanda entrou como signatária do Tratado Único Europeu (SEA) e começou uma fase de adaptações para melhorar todos os aspectos de sua economia.

O mercado presenciou uma grande abertura aumentando o volume de exportações, mas as exportações para sua vizinha Grã Bretanha começaram a diminuir e sua indústria manufatureira, a desaparecer. As expectativas de prosperidade que se tinham para o médio e longo prazo perderam a força. O governo adotou medidas 
financeiras de curto e curtíssimo prazo para aumentar a iniciativa de empreendimentos.

Mas o buraco que se abriu na conta da balança de pagamentos e nas contas nacionais gerou preocupações sobre se a economia irlandesa não era, de fato, fictícia. A falência do desenvolvimento interno inspirou muitos estudos no nível nacional.

Crotty (1986) afirma que a Irlanda deveria ser comparada a um país do terceiro mundo, no qual a estrutura social e política formadas pelo colonialismo são usadas pelo Estado de forma a favorecer as elites ${ }^{52}$. Segundo O'Hearn (1989), a falência de longo prazo da Irlanda foi devido à sua estratégia de mercado voltado ao exterior que caracterizou-se por um clássico caso de dependência, com crescimento baixo e desigualdade gerada por penetrações externas ${ }^{53}$. Já O’Malley (1989) assere que a Irlanda, como país de desenvolvimento tardio, enfrentou barreiras de mercado significativas devido a uma defasagem de escala, do poder do mercado ou de diferencial tecnológico que as economias maiores tinham ${ }^{54}$.

Não há dúvidas que essa premissa explica os dados que hoje podemos analisar com mais objetividade. Os índices de igualdade se mantiveram estáveis, ou diminuíram, no recorte temporal considerado, pois a classe rica irlandesa, os decis mais altos, pararam de investir e muitos chegaram a sair do país. Enquanto isso, o resto da população ficou mais homogênea, mas isso não significa mais rica ou com padrões de vida melhores. Nas décadas seguintes (1990-2000), o estado tentou implementar medidas de welfare no país.

Conforme o índice de Gini mostra para o período em análise (1970-2005), a Irlanda parece ter tido uma diminuição na desigualdade (média-ponderada) que poderia levar a reconsiderar seu modelo político de welfare e a redistribuição como policy de sucesso.

\footnotetext{
${ }^{52}$ Crotty, R. Ireland in Crisis: A Study of Capitalist Colonial Underdevelopment. Dingle: Brandon Book Publishers, 1986.

${ }^{53}$ O'Hearn, D. 'The Irish Case of Dependency: an Exception to the Exceptions?', American Sociological Review , 54, 1989, p. 578-96.

${ }_{54}$ O'Malley, E. Industry and Economic Development: the Challenge for the Latecomer. Dublin: Gill and Macmillan, 1989.
} 
Porém, se entrarmos em uma análise mais detalhada do plano social do país, percebemos que essas políticas não melhoraram o país de forma estrutural. Alguns estudos que foram conduzidos por pesquisadores irlandeses, mostram que houve um afastamento entre o decil mais baixo da população (bottom) e o decil mais rico (top).

A explicação, segundo Callan et al. (2013), é que as políticas de redistribuição se deram de forma simples do tipo top-bottom desconsiderando as faixas intermediárias que foram, assim, abrindo um gap que induziu uma polarização. Isso aconteceu pois as faixas da metade para baixo, mas não do primeiro decil, não tiveram ajuda e continuaram a ser taxadas indiretamente - descendo para o bottom -, ao mesmo tempo que as faixas da metade para cima, mas não do último decil, não foram taxadas e, assim, continuaram acumulando riqueza e aumentando o poder de compra - subindo para o top.

Callan et al. (2013) afirmam que

"the effects of discretionary changes in public policy made only a limited contribution to offsetting the effects of market forces. Instead, it was the crucial role of the automatic stabilizers in the tax and welfare system which played a major role in this outcome".

Porém, conforme se deduz dos dados, no caso da Irlanda essas práticas de welfare levaram ao fenômeno da polarização, conforme foi explicado antes:

"While the welfare system has played an importante role in providing protection for those at the bottom of the income distribution, including those who lost their Jobs during the recession, there is also a significant number of people in lower to middle income deciles who are suffering financial distress." 55

A taxa de risco à pobreza (At-risk-of-poverty rate) aumentou mais que a média dos outros países em análise, chegando até quase $20 \%$ em 2009. Isso indica, mais uma vez, um cenário de extrema instabilidade da estrutura social da população irlandesa.

A abertura do mercado na década de 1970 é apontada por muitos, conforme citado, como a causa da erosão da estrutura social irlandesa. A crise de 2008

\footnotetext{
${ }^{55}$ Maître, Russell e Whelan, 2014 apud Fitzgerald, 2014
} 
degradou muito o quadro do país que já vinha arrastando seus déficits nas contas públicas. Os efeitos da crise na economia irlandesa ainda são objeto de estudo, mas os últimos dados mostram uma oscilação na taxa de desemprego e uma ulterior polarização das rendas ${ }^{56}$.

${ }^{56}$ Fitzgerald (2014) 


\subsection{Romênia e Bulgária}

\section{Romênia}

A transição para a economia de mercado na Romênia foi associada ao crescimento da desigualdade, devido sobretudo à transição de economia planejada com distribuição igualitária para distribuição forçada pelo regime de mercado, cuja consequência é o aumento das diferenças de rendas de trabalho e de propriedades. Mas a Romênia alcançou os níveis mais altos de desigualdade de renda entre os estados da UE e há um gap significativo entre as condições de vida da maioria da população e a vida luxuosa dos ricos.

Existem, também, diferenças muito grandes entre as rendas dos empregadores, empregados e trabalhadores independentes e as dos trabalhadores da terra, dos desempregados e aposentados, e entre a renda de quem trabalha em áreas urbanas e áreas rurais, e a maioria desses valores tendem a se distanciar.

Isso levou à ideia de que há um processo de polarização social na Romênia, cujas evidências pode-se buscar também no fato de que algumas categorias da população que tradicionalmente integram a classe média, como professores e médicos, recebem ainda hoje salários relativamente muito baixos.

O único trabalho aprofundado no que concerne essa problemática para a Romênia é o paper de Molnar (2011) no qual se mostra a diferença de evolução entre Gini e polarização e entre a polarização antes e depois da redistribuição: 
Tabela 3: O impacto da redistribuição na bi-polarização de rendas.

\begin{tabular}{|c|c|c|c|c|c|}
\hline & 1995 & 2000 & 2006 & 2007 & 2008 \\
\hline \multicolumn{6}{|l|}{ Foster-Wolfson indices estimated for: } \\
\hline Disposable income & 0.231 & 0.243 & 0.266 & 0.261 & 0.253 \\
\hline Gross income & 0.257 & 0.262 & 0.304 & 0.303 & 0.291 \\
\hline $\begin{array}{l}\text { Gross income, before social transfers } \\
\text { (pension included in social transfers) }\end{array}$ & 0.365 & 0.385 & 0.473 & 0.470 & 0.465 \\
\hline $\begin{array}{l}\text { Gross income, before social transfers } \\
\text { (pension excluded from social transfers) }\end{array}$ & 0.272 & 0.279 & 0.327 & 0.324 & 0.309 \\
\hline \multicolumn{6}{|l|}{$\begin{array}{l}\text { Absolute polarization lessening due to } \\
\text { redistribution }\end{array}$} \\
\hline Total , out of which & -0.134 & -0.142 & -0.207 & -0.210 & -0.212 \\
\hline - due to social transfers, total & -0.108 & -0.122 & -0.170 & -0.167 & -0.174 \\
\hline - pensions & -0.093 & -0.106 & -0.146 & -0.146 & -0.156 \\
\hline - other social transfers & -0.015 & -0.017 & -0.023 & -0.021 & -0.019 \\
\hline $\begin{array}{l}\text { - due to income taxes and contributions } \\
\text { to social protection schemes }\end{array}$ & -0.026 & -0.019 & -0.038 & -0.042 & -0.037 \\
\hline \multicolumn{6}{|l|}{$\begin{array}{l}\text { As } \% \text { of total absolute lessening of } \\
\text { polarization due to redistribution }\end{array}$} \\
\hline Total , out of which & 100 & 100 & 100 & 100 & 100 \\
\hline - due to social transfers, total & 81 & 86 & 82 & 80 & 82 \\
\hline - pensions & 69 & 75 & 71 & 70 & 73 \\
\hline - other social transfers & 11 & 12 & 11 & 10 & 9 \\
\hline $\begin{array}{l}\text { - due to income taxes and contributions } \\
\text { to social protection schemes }\end{array}$ & 19 & 14 & 18 & 20 & 18 \\
\hline $\begin{array}{l}\text { Relative polarization lessening due to } \\
\text { redistribution, total (\%) }\end{array}$ & -37 & -37 & -44 & -45 & -46 \\
\hline
\end{tabular}

Fonte: Molnar, M. Income Polarization in Romania. 2011, p. 14.

Na Tabela 2 percebemos que existe uma mudança sensível à redistribuição social, sobretudo quando isso acontece com as aposentadorias. Mas Molnar (2011) segue demostrando que, apesar dos índices melhorarem, só pode se alcançar um melhoramento de longo prazo através de um entendimento mais aprofundado da sociedade e de cada classe de trabalho ${ }^{57}$.

Parecida com a maioria das outras economias da Europa do Leste depois de 1989, a economia romena tentou sobreviver durante os anos de transição conforme os meios o permitiram. Este equilíbrio precário foi repentinamente rompido em 1997, quando uma profunda recessão se manifestou com um declínio do PIB nacional que chegou ao valor de $-6,1 \%$ em relação ao ano anterior.

${ }^{57}$ Molnar (2011: 21) 
Em 2000, a recessão pareceu desacelerar com uma recuperação de $2 \%$. Repare-se que, desde a metade dos anos 1990, a Romênia foi o único país da área a ter sofrido uma recessão por três anos consecutivos, mostrando um decrescimento de $4 \%$ por ano. O governo começou a gastar mais do que o esperado e a inflação chegou ao valor de 154,9\% em 1997 (valor inferior, de toda forma, ao antigo 256\% de 1993, o mais alto da história do país).

O crescimento desproporcional dos preços em relação aos salários será um problema constante durante a transição, assim como nos últimos anos. As parcelas da riqueza nacional à qual a população deveria ter acesso não somente estavam diminuindo cada vez mais em relação às dos outros países do leste europeu mas, por causa do rápido aumento dos preços, valiam cada vez menos também em termos relativos.

Todas as rendas estavam se nivelando rumo ao bottom. Considerando somente a quota direcionada aos trabalhadores (de forma geral, à parte ativa da população) no ano central da recessão, e considerando a inflação, os salários valiam 56,8\% a menos em relação a 1996. Nos anos 1990-1999 sofreram um declínio médio de $40 \%{ }^{58}$.

No plano social, as consequências não foram, aparentemente, devastadoras se se observar somente o andamento do PIB per capita: a Romênia de Ceausescu era um país pobre e permaneceu com altos níveis de pobreza mesmo depois da queda do ditador. Entre 1989 e 1998 o PIB per capita se manteve em volta de US\$ 4 mil/ano, muito menor em relação ao de alguns países que em 2004 entraram na União Europeia; baixo, também, em relação ao da Bulgária e levemente mais alto somente em relação ao da Moldávia ${ }^{59}$.

A distribuição dessa renda, porém, piorou progressivamente e, combinado à queda dos salários, levou ao crescimento da pobreza interna. Em 1998, 44,5\% da população sobrevivia com menos de US\$ 4/dia, 6,8\% com menos de US\$

\footnotetext{
${ }^{58}$ OCSE 2000 Economic and Social Report

${ }^{59}$ World Bank Annual Report, 2004.
} 
2/dia. A Romênia era o único entre os países de economia parecida com mais de 10 milhões de pobres em uma população de 21 milhões de habitantes ${ }^{60}$.

Embora fosse o único país a mostrar uma tendência à diminuição da pobreza (de 35\% em 2000 até 28,9\% em 2002), os níveis deste fenômeno foram, e são, os mais altos desde a década de 1990. Considerando que a população vivia com rendas diretas (remuneração do trabalho), o problema da pobreza deve ser analisado juntamente com o do desemprego e das medidas de proteção social.

A repentina ruptura com o sistema de planejamento com salários, empregos e assistência garantidos representou um trauma e a falta de propulsão do sistema econômico subtraiu recursos preciosos para a constituição de um novo estado social no molde ocidental. Um dos aspectos comuns aos demais países em transição foi a reorientação estrutural da economia através do restabelecimento do setor industrial, que durante o planejamento sofria de perdas por causa de seu tamanho desproporcional.

O raciocínio à base dessa racionalização do setor é que teria se melhorado a eficiência total do sistema, eliminando uma quota de trabalhadores subocupados. Era, além disso, necessário aumentar e melhorar o setor terciário, aproximando-o dos padrões das economias avançadas. O setor manufatureiro expulsou, dessa forma, muitos trabalhadores: normalizando no valor 100 o número de empregados no setor industrial em 1989, em 13 anos a diminuição foi de 44,3\% e, segundo alguns estudos, isso foi um dos fatos que, entre 1995-1999, levou ao crescimento romeno, pois a eficiência total do emprego dos fatores de produção aumentou. Foi necessário, porém, evitar que o ganho de eficiência incidisse demasiadamente no aumento da taxa de desemprego, então, o governo decidiu aprovar uma lei que permitisse a aposentadoria para trabalhadores mais jovens. Apesar disso, em 1999, os desempregados alcançavam 11,5\% da força de trabalho.

\footnotetext{
${ }^{60} \mathrm{idem}$
} 
Emergem claros problemas de sustentabilidade das políticas de aposentadoria antecipada, pois, no mesmo ano, a relação entre trabalhadores que contribuíam socialmente e os aposentados desceu até 1,2 enquanto, em 1989, havia 4 trabalhadores para cada aposentado. Essa tendência explica-se pelo fato de que as leis do regime de Ceausescu previam que somente os trabalhadores do setor público e os do industrial contribuiriam socialmente e, conforme citado, essas categorias foram as que mais sofreram esse redimensionamento.

Por outro lado, é importante notar que as medidas de proteção social a favor de quem ainda estava empregado, mesmo assim, eram muito escassas. Segundo o Ministério do trabalho e da Proteção social na Romênia, normalizado a 100 o valor monetário dos benefícios das aposentadorias em 1990, para os seis anos seguintes, a diminuição foi de $39 \%$.

Rapidamente difundiu-se a marginalização das categorias mais fracas. Os auxílios previstos para as famílias com um único filho chegavam a cobrir somente $10 \%$ das necessidades básicas deste último ${ }^{61}$. O conflito distributivo dos aposentados entre quem recebia uma renda e quem não recebia renda nem apoio do Estado, foi paradoxalmente evitado por causa da pobreza generalizada a todas as categorias. Segundo Roner (2005), os desempregados representavam menos de $15 \%$ da pobreza total, enquanto os aposentados cobriam uma quota de mais de $30 \%$. As aposentadorias frequentemente não vinham emitidas por períodos entre 6 e 9 meses $^{62}$. O estado de pobreza há de se relacionar não somente às falhas do Estado social mas, também, às do mercado de trabalho, mesmo que as taxas de emprego e de produtividade daqueles anos estivessem mais altas que em outros países industrializados. Com este cenário, não são inesperadas formas de renda alternativas: o aumento da economia informal foi repentino, chegando a representar cerca de $18 \%$ da riqueza nacional.

Todos os indicadores sociais tiveram uma fortíssima queda na década de 1990, quando políticas neoliberais prevaleceram na maioria dos países. O governo eleito em 1996 fez reformas relevantes nesse sentido, eliminando o controle dos

${ }^{61}$ UNDP, Statistical Series: Romenia. 2005
${ }^{62}$ Roner, C. Romenia: heavy heritage. 2005 
preços e reduzindo os auxílios às empresas em dificuldade. Somente naquele ano, o governo romeno privatizou $60 \%$ das empresas públicas. A partir de então, os índices de pobreza afundaram-se cada vez mais e a desigualdade aumentou.

Todas as empresas estrangeiras que entraram no país criaram riqueza concentrada na elite do país e somente em algumas regiões. A desigualdade regional cresceu abruptamente e a entrada da Romênia ao mesmo tempo que a da Bulgária na União Europeia não melhorou esses valores. 


\section{Bulgária}

A Bulgária é um dos países que mais se ressentiram da transição da economia planejada para a abertura do mercado. De todos os indicadores, o mais impactante é sem dúvida o percentual de pobreza que, do período pré-abertura até 1993-94, passou de $5 \%$ para $32 \%$ da população. O número total de búlgaros que viviam abaixo da linha da pobreza em 1987-88 era de 3,6 milhões e pulou para 22,4 milhões em 1993-94; isto é, em apenas cinco anos os pobres quase quintuplicaram no país. Não é surpreendente ver que todos os indicadores de igualdade também sofreram uma mudança repentina e radical.

O índice de Gini, que nas décadas de 1960 e 1970 estava oscilando muito, tinha começado um caminho de diminuição logo no período pré-abertura do mercado. Infelizmente, essa tendência inusitada se reverteu com a transição do regime.

Gráfico 9: Evolução de Gini na Bulgária. 1980-2010

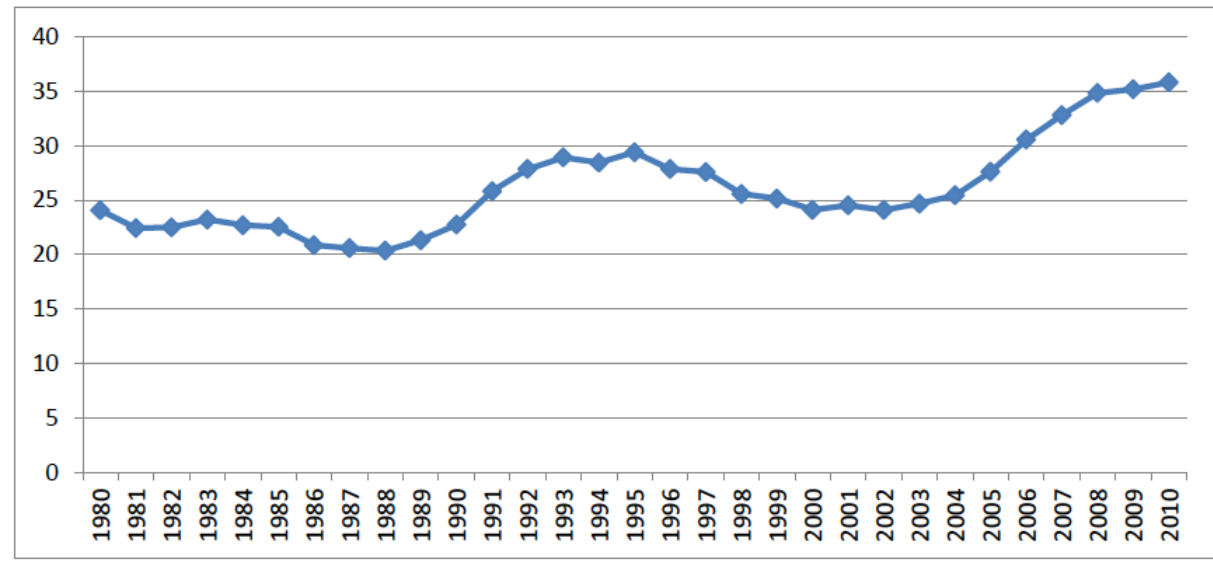

Fonte: Dados UN-SWIID. Elaboração própria.

No gráfico acima, se vê um valor mínimo de desigualdade em 1988 de 0,20. Depois desse ano, o índice de Gini começou a subir, se estabilizando em 0,24 por um breve período entre 2000 e 2002 e aumentando até mais de 0.35 em 2010 . 
O sistema de impostos nas rendas individuais e familiares tem um impacto imediato nas rendas líquidas. Comparar a desigualdade de rendas entre a renda familiar bruta e a renda familiar líquida nos ajuda a avaliar o impacto dos impostos na diminuição da desigualdade.

Se olharmos para o Gini antes e depois dos impostos, percebemos que houve uma tendência à diminuição das desigualdades nos últimos trinta anos, mas com diversos impactos. A política de impostos, desde a década de 1980 reduziu a desigualdade de renda de 12 a $15 \%$ com uma clara tendência ao enfraquecimento dos efeitos da taxação. A mesma política foi preservada até o início de 1990.

O efeito mais palpável na desigualdade pode ser observado no período 1994-2003 em relação às reformas no sistema tributário. Nesse período, a desigualdade de renda diminuiu, em média, cerca de 19\%. Nas condições de crescimento econômico e de superávit das contas públicas (2004-2008), a política de taxação teve efeito neutro pois os impostos foram diminuídos com iguais proporções. Como resultado disso, os efeitos na desigualdade diminuíram e, depois, permaneceram constantes para um longo período de tempo no valor de 13\%. Em 2008, a introdução do imposto à taxa única (idealizado por Milton Friedman em 1956) de $10 \%$ reduziu os efeitos na desigualdade até $10 \%$.

Depois da entrada do livre mercado, seguindo a linha neoliberal que se espalhou com força na década de 1990, o sistema de tributação foi, conforme analisado no pré e pós-abertura, se transformando pertinentemente com o novo regime econômico. Entre 2000 e 2010, os efeitos disso tornaram-se muito evidentes e os indicadores mostram uma clara inversão na tributação: 
Tabela 4a: Estrutura da arrecadação de impostos por tipo e por base do imposto na Bulgária. 2000-2010. (\% do PIB)

\begin{tabular}{|llllllllllll|}
\hline & $\mathbf{2 0 0 0}$ & $\mathbf{2 0 0 1}$ & $\mathbf{2 0 0 2}$ & $\mathbf{2 0 0 3}$ & $\mathbf{2 0 0 4}$ & $\mathbf{2 0 0 5}$ & $\mathbf{2 0 0 6}$ & $\mathbf{2 0 0 7}$ & $\mathbf{2 0 0 8}$ & $\mathbf{2 0 0 9}$ & $\mathbf{2 0 1 0}$ \\
\hline Structure by type & & & & & & & & & & & \\
Indirect taxes & 13.8 & 13.4 & 12.6 & 14.5 & 16.3 & 16.6 & 17.2 & 17.0 & 17.8 & 15.4 & 15.2 \\
Direct taxes & 6.9 & 7.5 & 6.4 & 6.2 & 6.0 & 4.9 & 5.2 & 8.2 & 6.7 & 5.9 & 5.1 \\
Social & 10.8 & 9.8 & 9.6 & 10.3 & 10.2 & 9.7 & 8.3 & 8.1 & 7.8 & 7.7 & 7.1 \\
contributions & & & & & & & & & & & \\
Structure by type of tax base & & & & & & & & & \\
Consumption & 13.2 & 12.8 & 11.9 & 13.8 & 15.5 & 15.9 & 16.6 & 16.5 & 17.2 & 14.7 & 14.5 \\
Labour & 14.0 & 12.5 & 11.9 & 12.7 & 12.5 & 11.6 & 10.1 & 10.4 & 9.7 & 9.8 & 9.0 \\
Capital & 4.4 & 5.5 & 4.7 & 4.5 & 4.5 & 3.8 & 4.1 & 6.5 & 5.3 & 4.5 & 3.9 \\
\hline
\end{tabular}

Fonte: Gini country Report, Bulgaria, 2012.

Vemos na tabela que os impostos diretos caem de $6,9 \%$ para $5,1 \%$ do PIB e as contribuições sociais de $10,8 \%$ para $7,1 \%$. O que, por outro lado, aumentou foi a taxação indireta que passou de $13,8 \%$ para $17,8 \%$ em 2008 e para 15,2\% em 2010. Além disso, os impostos que o consumo arrecadou aumentaram de 13,2\% para $14,5 \%$ (cobrindo quase todos os impostos indiretos).

A polarização na Bulgária acompanhou o andamento da desigualdade:

Tabela 4b: Desigualdade e polarização da parte da população trabalhadora. (Gini, centis 80/20, centis 90/10)

\begin{tabular}{|llll|}
\hline & Gini & S80/20 & S90/10 \\
\hline Total & & & \\
2002 & 0.342 & 6 & 9 \\
2006 & 0.381 & 6 & 10 \\
Men & & & 10 \\
2002 & 0.361 & 7 & 11 \\
2006 & 0.404 & 7 & 7 \\
Women & & & 9 \\
2002 & 0.309 & 5 & \\
2006 & 0.359 & 6 & \\
\hline
\end{tabular}

Fonte: Gini Country Report, Bulgaria, 2012.

A relação entre o segundo grupo mais rico $(\mathrm{S} 80)$ e o segundo mais pobre (S20) não varia muito, ao mesmo tempo que a relação entre o primeiro grupo mais rico (S90) e o primeiro mais pobre ( $\mathrm{S} 10)$ cresceu, indicando um aumento na polarização nos salários mais altos, sobretudo para a parte trabalhadora ocupada 
por mulheres. Isso, associado ao aumento da taxação indireta por consumo, exacerba ainda mais a diferença dos grupos pois esse tipo de taxação (consumo de bens e serviços) não considera a renda da classe que está consumindo. 


\subsection{Itália e Grécia}

\section{Itália}

Por toda a década de 1990, e durante o início da década de 2000, a desigualdade de renda na Itália alcançou níveis mais altos que os dos outros Estados da OCDE, sem, porém, mostrar significativas tendências. Esta evidência baseia-se principalmente na medição do mero nível de desigualdade, que pode não captar aspectos do conjunto da da densidade de pessoas nas faixas de rendas, assim como a polarização. A distribuição relativa, o principal elemento para medir a polarização, descreve tendências às mudanças da distribuição de rendas na Itália entre 1989 e 2006. Durante esse período, a Itália vivenciou um aumento significativo da polarização das rendas familiares, o que afetou sobretudo a primeira metade (mais pobre) da população. Além disso, essa polarização relativa é primeiramente atrelada às mudanças de renda nos chefes de família, que detinham a possibilidade mais significativa de contribuição à renda familiar ${ }^{63}$.

Essas evidências nos permitem analisar tanto o caso da Itália quanto o de outros países da área "mediterrânea", os quais tiveram um período prolongado de recessão seguido por uma fase de crescimento lento desde 1993 e até a crise de 2008. Durante as últimas quatro décadas houve, também, uma transformação no mercado de trabalho com o aumento do trabalho contingente, o que implicou uma distribuição de renda mais pulverizada desde os anos $1990^{64}$.

$\mathrm{Na}$ mesma época, a redistribuição interna mitigou os efeitos negativos que essas transformações geraram. De qualquer maneira, a transformação no mercado de trabalho acarretou uma série de novos fenômenos como, entre outros, o envelhecimento da população ativa, os quais, combinados ao período de estagnação depois da recessão, fizeram com que começasse a se verificar uma polarização nas rendas ${ }^{65}$.

\footnotetext{
${ }^{63}$ Brandolini et al. (2001)

${ }^{64}$ idem

${ }^{65}$ Massari (2009: 12)
} 
Tabela 5: Rendas disponíveis por núcleo familiar na Itália, 1989-2006.

\begin{tabular}{cccccccccc}
\hline & 1989 & 1991 & 1993 & 1995 & 1998 & 2000 & 2002 & 2004 & 2006 \\
\hline Sample size & 8274 & 8188 & 8089 & 8135 & 7147 & 8001 & 8011 & 8012 & 7768 \\
Mean & 22157 & 22347 & 21148 & 20807 & 22658 & 22863 & 23329 & 25207 & 26064 \\
Median & 18589 & 19089 & 17908 & 17639 & 18612 & 19356 & 19980 & 20839 & 21480 \\
\hline Bottom 5\% & 1.42 & 1.36 & 0.88 & 0.94 & 0.76 & 0.86 & 0.92 & 1.04 & 1.02 \\
Bottom 10\% & 3.44 & 3.39 & 2.61 & 2.65 & 2.37 & 2.54 & 2.64 & 2.75 & 2.75 \\
Bottom 20\% & 8.38 & 8.33 & 7.18 & 7.18 & 6.70 & 7.02 & 7.31 & 7.12 & 7.23 \\
Top 20\% & 39.53 & 38.81 & 40.86 & 40.68 & 42.58 & 40.96 & 40.37 & 42.10 & 41.69 \\
Top 10\% & 24.87 & 23.99 & 25.70 & 25.60 & 27.93 & 26.07 & 25.43 & 27.51 & 27.14 \\
Top 5\% & 15.73 & 15.02 & 15.98 & 16.11 & 18.41 & 16.56 & 15.82 & 18.07 & 18.00 \\
\hline
\end{tabular}

Fonte: Massari, 2009: 12. Dados do SHIW normalizados e calculados com os preços de 2000.

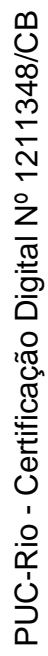

Na tabela se vê um aumento da concentração sobretudo no top $10 \%$ de 1989 a 2006. Olhando mais de perto a tendência que se verificou naqueles anos, achamos um aumento significativo na polarização de algumas rendas:

Gráfico 10: Índices de polarização relativa na Itália, 1989-2006

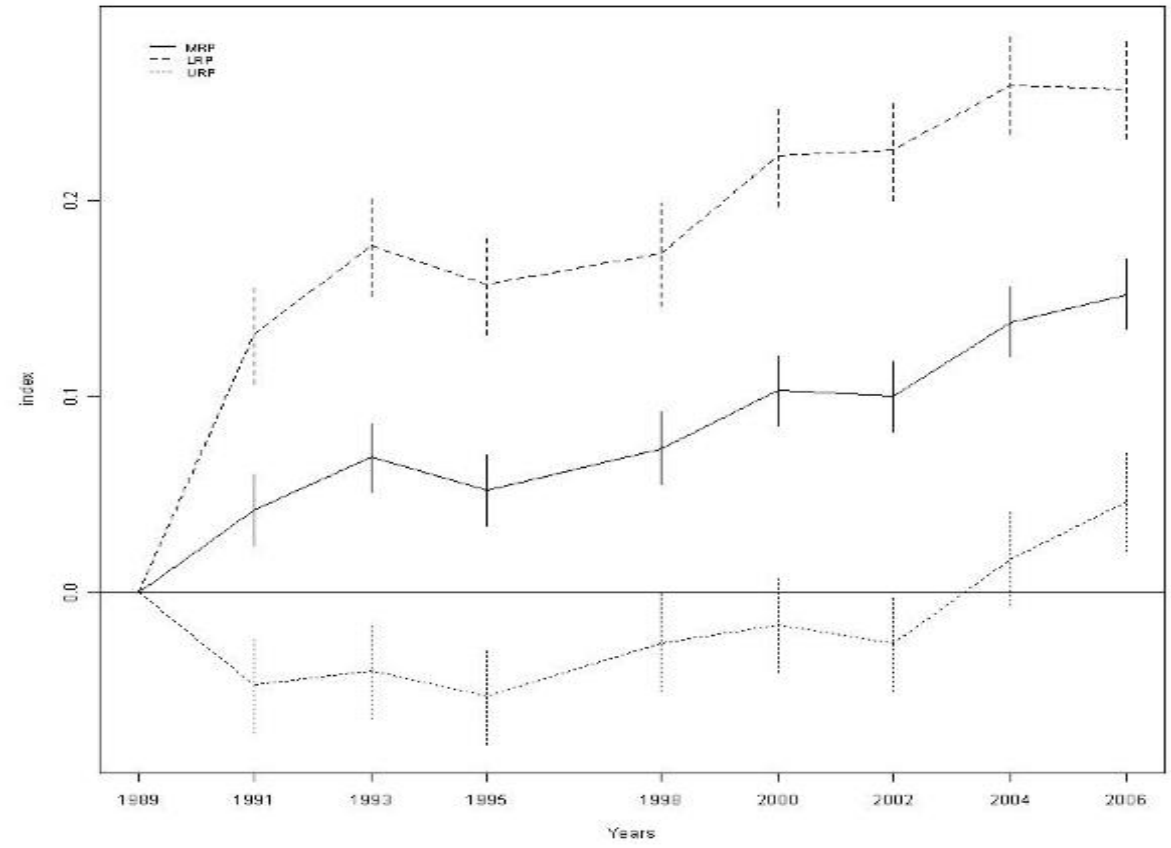

Fonte: idem, p. 16 
Nas curvas do gráfico, a linha contínua representa a polarização média de alguns índices. Vemos que sua tendência indica um aumento na polarização desde o início do período estudado. De 1995 a 2000, a polarização das rendas aumentou vagarosamente, depois de ter tido um aumento abrupto nos poucos anos entre 1989 e 1995.

Gráfico 11: Distribuição relativa das rendas na Itália, 1986-2000

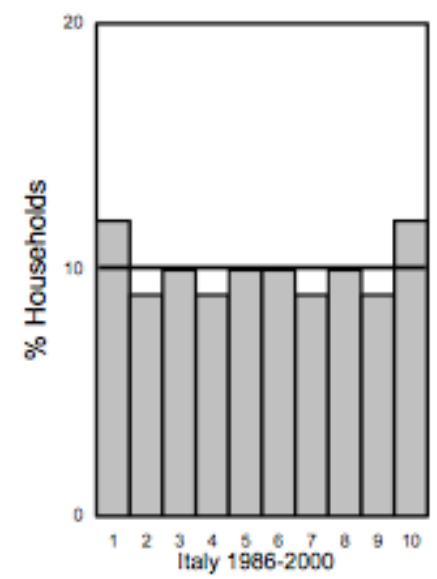

Fonte: Alderson, A. S., Beckfield, J., Nielsen, F. Exactly how has income inequality changed? Patterns of distributional change in core societies, LIS Working Paper Series, No. 422, 2005, p. 24

Seguiu um breve período de estabilização a partir de 2000 e, em 2004, houve uma mudança significativa na forma da distribuição, o que indica um outro aumento na polarização das rendas. Em 2006, a tendência continua com uma inclinação rumo ao aumento, mesmo que não tenha tido nenhum outro comportamento anômalo e repentino no intervalo do gráfico.

Estudos aprofundados nessa análise, sobretudo Massari (2009), afirmam que houve, no primeiro período, uma polarização nas rendas baixas e que isso seria devido sobretudo a uma diminuição dos salários. Já, a partir de 2002, o polo do top começa a crescer novamente. O resultado seria devido ao fato de que, enquanto os decis do top começaram, desde então, a ganhar salários cada vez maiores (subindo para degraus mais altos), os decis do bottom continuaram a perder espaço no mercado. 
O aumento mais visível da desigualdade seguiu a crise de 1992, depois que os primeiros efeitos da recessão, a redução nos salários e os cortes dos gastos públicos se manifestaram. Houve um desaceleramento no crescimento do PIB que levou a uma diminuição na demanda de empregos, cujos efeitos ecoaram mais insistentemente considerando que o poder de compra dos salários diminuiu drasticamente quando a lira sofreu uma desvalorização ${ }^{66}$.

Os salários sofreram um congelamento depois dos acordos assim chamados de "concerto tripartidário" entre governo, empregadores e sindicatos. Estes últimos seguiram a abrogação do aumento dos salários reais. As medidas para reduzir o déficit público e enfrentar a dívida não deixaram espaço para políticas de redistribuição e de incentivo aos empregos. Ao mesmo tempo, as privatizações maciças que ocorreram na década de 1990 cortaram uma boa parte dos trabalhos bem remunerados com uma migração dos valores para os mínimos salariais.

Esta foi a década durante a qual o país mediterrâneo iniciou seu caminho na desigualdade, o que coincidiu com um declínio, também, na sua capacidade econômica. Desde então, o país, igualmente a outros da área, não teve mais um melhoramento significativo nessas variáveis ${ }^{67}$.

\footnotetext{
${ }^{66}$ Pianta, M. Nine out of ten. The "losers" in Italy's long crisis. Changes in income distribution, effects of policies, rise in inequality. 2012, p. 6

${ }^{67}$ idem
} 


\section{Grécia}

Se não houvesse a crise que abalou a economia internacional deixando-a em um momento de profunda recessão, a Grécia já faria parte daquelas economias com problemas estruturais peculiares da área meridional da Europa. Se somarmos a essas peculiaridades culturais, os efeitos que os rastros da crise de 2008 deixaram na economia grega, temos um quadro mais fiel de como uma economia mediterrânea, com baixa diversificação produtiva e problemas internos regionais, não tem os meios para enfrentar dificuldades sistêmicas e de como isso fere primeiramente a formação social do país.

A Grécia apresenta essas peculiaridades também por ter vivenciado, assim como Portugal, uma transição para a democracia relativamente tardia, a partir de 1974. Em um primeiro momento, de 1974 a 1981, o crescimento econômico foi considerável, a taxa de desemprego diminuiu mas os índices sociais permaneciam negativos. De 1982 a 1994, o setor público desempenhou um papel fundamental e a política da época viu uma participação ativa da população graças ao reforço da voz de alguns partidos de esquerda (sobretudo o Partido Panhelênico Socialista). De toda forma, a desorganização das políticas públicas e dos planos macroeconômicos de longo prazo foram prelúdios para uma recessão do país, acompanhada por altos índices de desemprego e estagnação econômica que contribuíram para elevar a dívida pública a níveis preocupantes. De 1994 a 2009, a economia apresentou melhoras em todos os indicadores. Obviamente, os problemas desse modelo de crescimento teriam se manifestados mais tarde, nos ecos da crise, quando a estrutura da economia grega começou a apresentar falhas muito significativas, sobretudo geradas por um sistema de empréstimos do exterior que a Grécia estava alimentando. A taxa de desemprego de 25,1\% de 2012 foi a variável mais contingente dessa fase que ficou conhecida como a Grande Depressão Grega ${ }^{68}$.

\footnotetext{
${ }^{68}$ Katsimi , M., Moutos, T., Pagoulatos, G., Sotiropoulos, D. Growing inequalities and their impacts in Greece, 2013, p. 1
} 
Gráfico 12: Salários proporcionais ao PIB na Grécia. 1970-2011

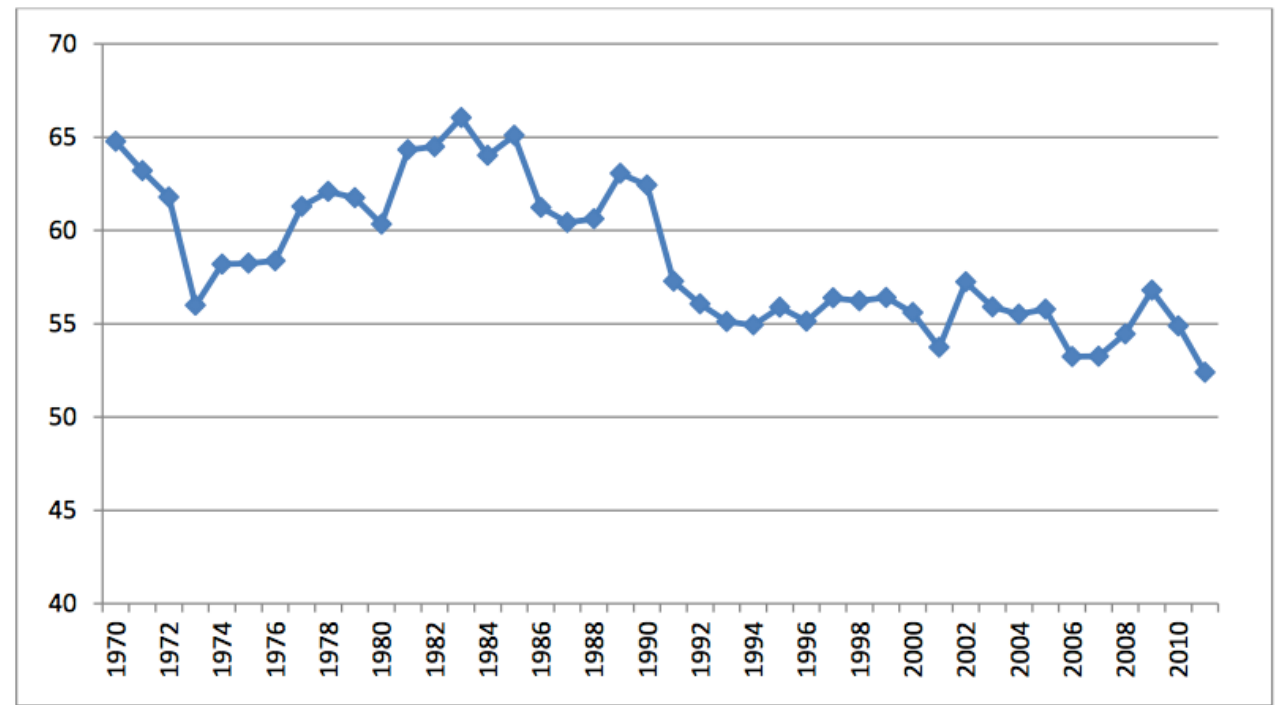

Fonte: Katsimi , M., Moutos, T., Pagoulatos, G., Sotiropoulos, D. Growing inequalities and their impacts in Greece, 2013, p. 11

No que concerne o andamento da desigualdade do país, o primeiro período de crescimento associado ao início do regime democrático conseguiu diminuir o índice de Gini de 19\%. Porém, na fase de estagnação que seguiu, e com o aumento do desemprego até $9 \%$, a faixa de renda mais baixa sofreu um aumento repentino induzindo uma polarização nos decis mais baixos.

Com o melhoramento na economia e a implementação de algumas medidas de welfare, a primeira década de 2000 viu uma diminuição do desemprego e da desigualdade. Essa fase aparentemente próspera, porém, não aparentou ter tido bases sólidas para enfrentar os efeitos que a crise de 2008 trouxe: o salário mínimo diminuiu em $25 \%$, o desemprego voltou e as medidas de welfare foram arquivadas indefinidamente. $\mathrm{O}$ ramo da educação, também, refletiu a estratificação social formada, com qualidade e acesso de alto nível para as faixas de alta renda. Dessa forma, este círculo vicioso de recessão-educação-recessão criou uma polarização ainda mais acentuada nas faixas de alta e altíssima renda. 
Gráfico 13: Curva de Polarização Absoluta na Grécia, 2010.

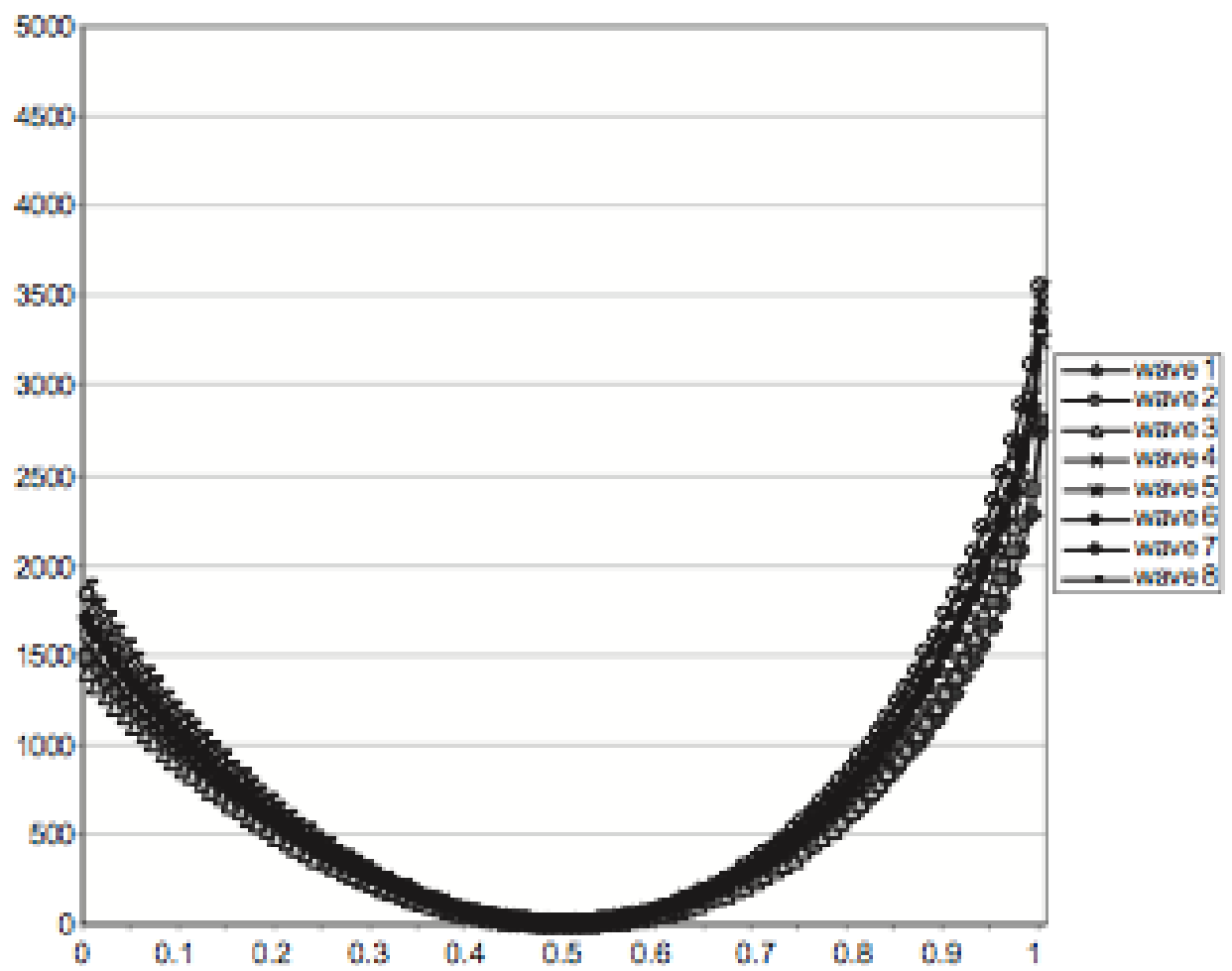

Fonte: D’Ambrosio, C., Chakravarty, S. R., Polarization Orderings of Income Distributions. 2010, p. 58.

Pela curva, podemos ver que todos os valores mais altos e mais baixos tiveram leves oscilações (no gráfico, waves) para cima ou para baixo, enquanto as faixas do meio (supostamente "classe média") permaneceram quase inexistentes.

A época de recuperação pós-crise ainda não terminou e as políticas de austeridade que a Grécia adotou para salvar sua economia não parecem ter mostrado sinais positivos na estrutura social do país. Para completar o cenário negativo do país mediterrâneo, segundo a Hellenic Statistical Authority (ELSTAT), 23,1\% dos gregos estão em risco de pobreza, contra 19,7\% em 2009. Isso equivale a cerca de 900000 famílias que podem repentinamente cair para salários familiares de 11 900 euros por ano (núcleos de dois adultos com dois filhos). 
Gráfico 14: Taxa de risco à pobreza da Grécia. 2008-2012

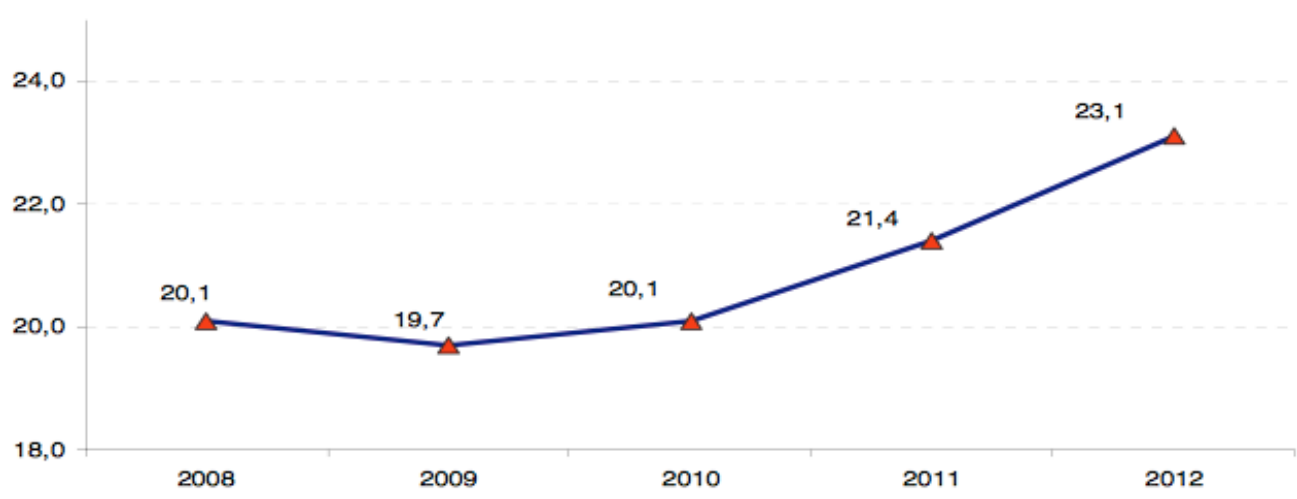

Fonte: ELSTAT, Statistics on Income and Linving Conditions 2012. 2013, p. 1 


\section{Conclusões}

A estrutura social nos países das diversas áreas do continente europeu apontados aparenta ter uma formação ainda mais preocupante pela falta de mobilidade; característica mais permanente do que o próprio índice de Gini mostrava com a variação da desigualdade. Isto, lido em uma chave históricomaterialista, nos fornece um retrato fiel de como os processos econômicos que viram uma mundialização do capital no último século permearam as relações sociais através das relações produtivas.

Uma análise baseada nos índices de polarização mostrou que a maioria dos países europeus ou apresenta uma cristalização social que não permite mobilidade ou apresentou, no último século, uma aglutinação nas faixas mais baixas e mais altas da população criando um espaçamento onde deveriam existir as faixas intermediarias, contribuindo para formar uma estrutura mais igualitária e participativa.

A perspectiva marxiana utilizada para interpretar e entender esses fenômenos nos sugere que, nesses países onde a interligação com o capital internacional é forte e onde o aparato produtivo ainda vangloria uma acumulação de capital extraída do trabalho, a única herança que passa de uma geração para a seguinte é a apropriação dos meios de produção, por um lado, e a subjugação ao poder decorrente desta apropriação, do outro.

Mesmo naqueles países onde as medidas de welfare caracterizaram inteiras décadas, as políticas sociais redistributivas criaram, na maioria das vezes, resultados parecidos com os alcançados pelas políticas de austeridade no que concerne à estrutura social do país. Isso é imputável, também, ao fato de que a taxação com finalidade redistributiva é uma taxação direta que, em muitos casos, não foi acompanhada por uma diminuição da taxação indireta. Esta última, continuando a incidir nos consumos, teve mais impacto negativo nas baixas rendas. Isso criou uma polarização nas rendas dos extremos e pouco resolveu (às vezes piorou) a falta de uma classe média. 
Ao contrário do que alguns afirmam (ex. Piketty), a redistribuição não é uma caixa preta que representa a solução mais eficiente e a mais duradoura a ser aplicada, pois, ao se esperar um efeito equalizador no longo prazo, na maioria das vezes se enxergam somente novas desigualdades. Nesse sentido, uma análise da polarização é crucial para analisar os efeitos das políticas redistributivas no lugar dos índices de desigualdade "puros" (ex. Gini, Thail, etc) que, ao contrário, são sensíveis positivamente a esses tipos de políticas.

Os Estados das áreas apontadas na pesquisa implementaram políticas parecidas mas em períodos diferentes, o que gerou tendências ao aumento, ou diminuição, da desigualdade (Gini) em períodos diferentes. Porém, apesar das realidades pontuais que em cada país formaram suas histórias político-econômicas, uma visão mais ampla nos mostra que a estrutura social de todos eles apresenta uma importante falta de distribuição nas rendas como resultado de um processo - que foi lido na chave histórica materialista - envolvendo a evolução do mercado e a relação do Estado com este.

A pesquisa desenvolvida visou apresentar os elementos principais que precisam ser levados em conta quando se quer estudar a formação e a evolução da desigualdade nas diversas áreas europeias e do continente como um tudo. Obviamente, o trabalho representa somente um input inicial para futuras pesquisas. Estas, porém, devem priorizar a colocação da ontologia materialista ao centro da lógica de estudo se quiserem entender como se deu a estruturação socioeconômica em decorrência das fases evolutivas do capital.

Parafraseando Marx, as relações produtivas são as relações que mais definem todas as outras relações e, dessa forma, a evolução do mercado pode nos explicar porque os Estados reagiram de determinadas formas visando, sempre, priorizar e salvaguardar o capital, antes nacional e, depois de sua mundialização, participando de sua expansão e acumulação contínua.

Ao seguir um caminho sustentado pela teoria crítica das Relações Internacionais, é imprescindível pensar no capital como um processo. É, portanto, preciso estudar 
o comportamento adotado pelos Estados nacionais em relação ao mercado interno e ao mercado mundializado tendo em mente que o padrão de crescimento universalmente reconhecido prevê como fim último a expansão do capital e que esta última não existe sem adaptações das relações produtivas que garantam a extração de mais-valia do trabalho.

À luz da consideração inicialmente apontada por Cox, o campo de ação destes atores, cuja forma revela uma estrutura histórica, muda ao longo do tempo e a teoria crítica tem como objetivo principal entender essas mudanças. O estudo desenvolvido nasceu da insatisfação que análises geralmente bem conceituadas, como a do índice de Gini, geraram em orientar os resultados como se fossem produtos sem indagar em profundidade como se deu a formação da estrutura social em termos históricos e materiais. 


\section{Apêndice}

Tabela 1: Evolução quinquenal de Gini da Europa por regiões. 19702005

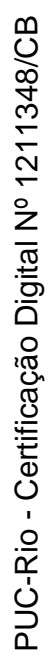

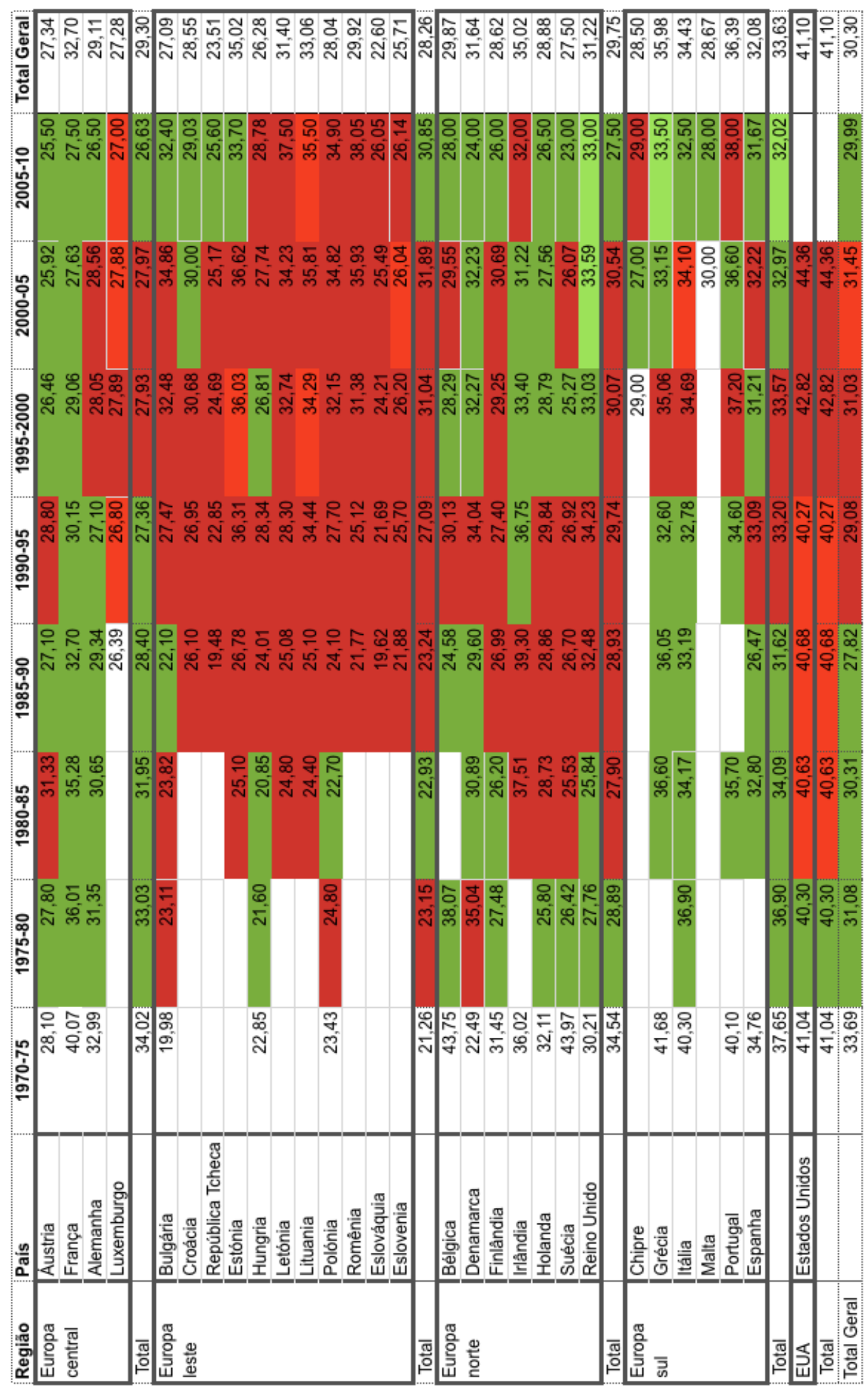


A elaboração da Tabela 1 desenvolveu-se com base nos dados UNU-WIDER (2012) do histórico de Gini por diversos países. A trajetória de elaboração começou selecionando os países por região. Não existindo os índices de todos os anos para todos os países, fez-se uma média ponderada quinquenal para os diversos países, partindo do quinquênio 1970-1975 e terminando com o quinquênio 2005-2010. Esses foram os anos que mais interessaram a pesquisa e as tendências posteriormente observadas reforçaram ainda mais este interesse.

Depois que o agrupamento e a média foi realizada, observaram-se as diminuições e os aumentos dos índices. Tentou ressaltar-se a diferença entre um aumento e uma diminuição forte e repentina e um aumento e uma diminuição leve e progressiva. Em termos gráficos, no primeiro caso foram usados respectivamente o vermelho e o verde escuros e, no segundo, o vermelho e o verde claros.

Foi, outrossim, observada a média por região para ver se a tendência de Gini refletia de forma fiel a estrutura social da região em questão, através (como se viu nos Capítulo 6) o índice de polarização. Foi feita, da mesma forma, uma análise do índice de Gini para os EUA, com objetivo de mostrar quanto a desigualdade esteja relacionada de forma inversamente proporcional ao crescimento e aprimoramento do sistema capitalista.

Uma média dos anos, por país, foi exposta na coluna da direita para fazer uma comparação entre o Gini inicial do período de cada país com seu Gini final e, através da média, ter um impacto rápido e visual de comparação entre o histórico dos vários países. 


\section{9. \\ Referências bibliográficas}

ALDERSON, A. S.; BECKFIELD, J.; NIELSEN, F. Exactly how has income inequality changed? Patterns of distributional change in core societies, LIS Working Paper Series, No. 422, 2005.

ALESINA, A.; PEROTTI, R. Income distribution, political instability and investment em European Economic Review, 40, 1203-1228 p., 1996.

ANDERSON, G. Toward an Empirical Analysis of Polarization em Journal of Econo-metrics 122: 1-26 p., 2004.

ATKINSON, A. The Welfare State and Economic Performance, 1995.

BANERJEE, A.; DUFLO, E. Inequality and Growth: What Can the Data Say? Em Journal of Economic Growth, 8(3), 267-299 p., 2003.

BARRO, R. Inequality and Growth in a Panel of Countries em Journal of Economic Growth, Springer, Vol. 5, No. 1, 5-32 p., mar. 2000.

BERBEROGLU, B. Globalization and Change: The Transformation of Global Capitalism, 2005.

BRANDOLINI A.; CIPOLLONE P.; SESTITO P. Earnings dispersion, low pay and household poverty in Italy, 1977-1998 em Cohen, D.; Piketty, T.; Saint-Paul, G. (ed.), The Economics of Rising Inequalities, 225-264 p., Oxford University Press, Oxford, 2001.

BRAUDEL, F. La dynamique du capitalisme, Paris, Arthaud, 1985

BRZEZIŃSKI, M. Income Polarization and Economic Growth em National Bank of Poland Working Paper, 47, 2013.

BURTLESS, G. Globalization and Income Polarization in Rich Countries, em Issues in Economic Policy, The Brookings Institute, abr. 2007.

CALLAN ET AL. Crisis, response and distributional impact: the case of Ireland, 2014.

CHAKRAVARTY, S.; MAJUMDER, A. Inequality, polarization and welfare: theory and applications em Australian Economic Papers, 40(1), 1-13 p., 2001.

CLARKE, G. More evidence on income distribution and growth em Journal of Development Economics, 47(2), 403-427 p., 1995. 
CLEMENTI, F.; SCHETTINO, F. Income Polarization in Brazil, 2001-2011: A Distributional Analysis Using PNAD Data, 2013.

COCKS, P. Towards a Marxist Theory of European Integration em International Organization, 34, I, inverno 1980.

$\mathrm{COX}, \mathrm{R}$. Social forces, states and world orders. Beyond international relations theory em Keohane, R. (Ed): Neorealism and its critics. Columbia University, New York, 1986.

COX, R. Production, power and world orders. Social forces in the making of history. Columbia University Press, New York, 1987.

CRÉCHET, J. Libéralisation commerciale, développement financier et inégalités de revenu. Université de Montréal, 2012.

CROTTY, R. Ireland in Crisis: A Study of Capitalist Colonial Underdevelopment. Dingle: Brandon Book Publishers, 1986.

D'AMBROSIO, C. Household Characteristics and the Distribution of Income in Italy: An Application of Social Distance Measures em Review of Income and Wealth, Vol. 47, No. 1, 2001.

D'AMBROSIO, C.; CHAKRAVARTY, S., Polarization Orderings of Income Distributions. 2010.

DALTON, R. Social modernization and the end of ideology debate: Patterns of ideo- logical polarization em Japanese Journal of Political Science, 7, 1-22. 2006.

DALTON, R. The Quantity and the Quality of Party Systems em Comparative Political Studies, Vol. 20, No. 10, 2008.

DEININGER, K.; SQUIRE, L. New ways of looking at old issues: inequality and growth em Journal of Development Economics, 57(2), 259-287 p., 1998.

DEUTSCH, J.; FUSCO, A.; SILBER, J. The BIP Trilogy (Bipolarization, Inequality and Polarization): One Saga but Three Different Stories em Economics E-Journal, Vol. 7, No. 2013-22, 2013. 
DUCLOS, J.; ESTEBAN, J.; RAY, D. Polarization: concepts, measurement, estimation em Econometrica, 72(6), 1737-1772 p., 2004.

ELSTAT, Statistics on Income and Linving Conditions 2012, 2013.

ENDRE, S. The Political and Economic Transition in Hungary, 2004.

ESTEBAN, J.; RAY, D. On the measurement of polarization em Boston University - Institute for Economic Development Working Paper 18, Boston University, 1991.

ESTEBAN, J.; RAY, D. Conflict and distribution em Journal of Economic Theory, 87(2), 379-415 p., 1999.

ESTEBAN, J.; RAY, D. Comparing Polarization Measures em M. Garfinkel and S. Skaperdas, Oxford Handbook of the Economics of Peace and Conflict, Oxford University Press, Oxford, 127-151 p., 2012.

ESTEBAN, J.; RAY, D. Linking Conflict to Inequality and Polarization em American Economic Review 2011, 101, 1345-1374 p., 2012.

EUROSTAT Single Market Scoreboard n. 2, 1998.

FITZGERALD, J. The Distribution of Income and the Public Finances, 2014.

FORBES, K. Reassessment of the Relationship between Inequality and Growth em American Economic Review, 90(4), 869-887 p., 2000.

GILPIN, R. A Economia Política das Relações Internacionais, 1987.

Gini Country Report, Bulgaria. 2012.

Gini Country Report, Greece. 2012.

GINI, C. L'ammontare e la composizione della ricchezza delle nazioni, Torino, Bocca, 1910.

GINI, C. Sulla misura della concentrazione e della variabilità dei caratteri, Venezia, 1914.

GORNICK, J. Inequality, it metters. LIS Center, 2013.

GRABKA, M.; GOEBEL, J. Reduction in Income Inequality Faltering em DIW Economic Bulletin, No. 1, 2014. 
GRABKA, M.; GOEBEL, J.; SCHUPP, J. Has Income Inequality Spiked in Germany? em DIW Economic Bulletin, No. 12, 2012.

HELLEINER, E. Explaining the Globalization of Financial Markets: Bringing States Back in em Review of International Political Economy, Vol. 2, No. 2, 31541 p., primavera 1995.

HELLEINER, E. States and the Reemergence of Global Finance: From Bretton Woods to the 1990s. Cornell University Press, 1996.

HOLZNER, M. The Determinants of Income Polarization on the Household and Country Level across the EU, Working Paper, 93 de "The Vienna Institute for International Economic Studies", 2012.

INEQUALITY WATCH The Evolution of Income Inequalities in Germany, 2013

Katsimi , M., Moutos, T., Pagoulatos, G., Sotiropoulos, D. Growing inequalities and their impacts in Greece, 2013.

KUZNETS, S. National Income and Its Composition, 1919-1938, 1941.

KUZNETS, S. Secular Movements in Production and Prices, 1930.

LAKNER, C.; MILANOVIC, B. Global Income Distribution: from the fall of the Berlin Wall to the Great Recession em World Bank Working Paper No. 6719, dez. 2013.

LI, H.; ZOU, H. Income Inequality is not Harmful for Growth: Theory and Evidence," Review of Development Economics, 2(3), 318-334 p., 1998.

LIN, S.; HUANG, H.; KIM, D.; YEH, C. Nonlinearity between Inequality and Growth em Studies in Nonlinear Dynamics \& Econometrics: Vol. 13: No. 2, Article 3, 2009.

LUCENTE, S. Le più Grandi Imprese Transnazionali: loro Struttura e Peso Economico “Inestimabile”, Sapienza Università Editrice, 2009.

LUNDESTAD, G. Empire by Invitation? The United States and Western Europe, 1945-1952 em Journal of Peace Research, Vol. 23, No. 3, set. 1986.

MAITO, E. Piketty against Piketty: the tendency of the rate of profit to fall in United Kingdom and Germany since XIX century confirmed by Piketty s data. Munich Personal RePEc Archive, 2014. 
MANDEL, E. International Capitalism and "Supra-nationality em Socialist Register, Merlin Press, London, 27-41 p., 1967.

MARX, K. Il Capitale, 1867.

MARX, K. Para a Crítica da Economia Política, 1859.

MASSARI, R.; PITTAU, M.; E ZELLI, R. A dwindling middle class? Italian evidence in the 2000s em Journal of Economic Inequality, vol. 7(4), 333-350 p., 2009.

MIKHALEV, V. Inequality and Transformation of Social Structures in Transitional Economies em UNU WIDER Research for Action 52, 2000.

MILANOVIC, B. Income, Inequality, and Poverty during the Transition from Planned to Market Economy, The World Bank, Washington, DC, 1998.

MOLNAR, M. Income Polarization in Romania, 2011.

O'HEARN, D. The Irish Case of Dependency: an Exception to the Exceptions?,em American Sociological Review , 54, 578-96 p., 1989.

O'MALLEY, E. Industry and Economic Development: the Challenge for the Latecomer. Dublin: Gill and Macmillan, 1989.

OCSE 2000 Economic and Social Report, 2001.

OECD, Growing Unequal? Income Distribution and Poverty in OECD Countries, 2008.

OLIVER, X.; PICCOLI, L.; SPADARO, A. Redistribution and Polarization Impact of the European Redistribution Architecture: an Analysis Using Microsimulation Techniques, 2008. 
PANITCH, L.; GINDIN, S. Global Capitalism and American Empire em Socialist Register, 2004.

PERSSON, T.; TABELLINI, G. Is Inequality Harmful for Growth? Theory and Evi- dence," American Economic Review, 84(3), 600-621 p., 1994.

PIANTA, M. Nine out of ten. The "losers" in Italy's long crisis. Changes in income distribution, effects of policies, rise in inequality, 2012.

PIKETTY, T. ET AL. Inégalités économiques, 2001.

PIKETTY, T. Le Capital au XXIe siècle, 2013.

PIKETTY, T. Technical Appendix of the book "Capital in the 21st century". 2014

PIKETTY, T. Top incomes over the twentieth century, 2013.

ROBINSON, R.; KELLEY, J. Class as conceived by Marx and Dahrendorf: effects on income inequality and politics in the United States and Great Britain, 1979.

RONER, C. Romenia: heavy heritage, 2005.

SCHETTINO, F. Polarizzazione e Disuguaglianza: Rapporti di Produzione e Distribuzione del Reddito em Contraddizione, No. 148, 2014.

SEN, A. On Economic Inequality. 1973.

SMITH, C. Ireland, em Wankel, C. (ed.) Encyclopedia of Business in Today's World, California, USA, 2009.

TORRES, E. A Crise do Sistema Financeiro Globalizado Contemporâneo, 2013.

TORRES, E. A Economia Monetária, a Poupança e o Finaciamento do Tratado à Teoria Geral em Revista de Economia Política, vol. 11, n. 2 (42), abr.-jun. 1991. 
TRADING ECONOMICS Germany Inflation Rate, 2013.

TRADING ECONOMICS United States Inflation Rate, 2013.

TYLER, P.; MARTIN, R.; ARESTIS, P. The Persistence of Inequality? em Cambridge Journal of Regions, Economy and Society 2011, 2011.

UNDP Statistical Series: Romenia, 2005.

UNU-WIDER World Income Inequality Database, Version 2.0c (suporte eletrônico), 2008.

WALLERSTEIN, I. World-Systems Analysis: Theory and Methodology, 1982.

WOOD, E. O que é (anti) capitalismo? em Crítica Marxista, 2003.

WORLD BANK Annual Report, 2004. 